Hydrol. Earth Syst. Sci. Discuss., doi:10.5194/hess-2016-683, 2017

\title{
Scaling down hyporheic exchange flows: from catchments to reaches
}

\author{
Chiara Magliozzi ${ }^{1}$, Robert Grabowski ${ }^{1}$, Aaron I. Packman ${ }^{2}$, and Stefan Krause ${ }^{3}$ \\ ${ }^{1}$ Cranfield Water Science Institute, Cranfield University, Cranfield, MK43 OAL, UK \\ ${ }^{2}$ Department of Civil and Environmental Engineering, Northwestern University, Evanston, Illinois, USA \\ $5{ }^{3}$ School of Geography, Earth and Environmental Sciences, University of Birmingham, Edgbaston, Birmingham, B15 2TT, \\ UK
}

Correspondence to: Robert Grabowski (r.c.grabowski@cranfield.ac.uk)

Abstract. Rivers are not isolated systems but continuously interact with the subsurface from upstream to downstream. In the last few decades, research on the hyporheic zone (HZ) from many perspectives has increased appreciation of the hydrological importance and ecological significance of connected river and groundwater systems. Although recent reviews, modelling and field studies have explored hydrological, biogeochemical and ecohydrological processes in the $\mathrm{HZ}$ at relatively small scales (bedforms to reaches), a comprehensive understanding of the factors driving the hyporheic exchange flows (HEF) at larger scales is still missing. To date, there is fragmentary information on how hydroclimatic, hydrogeologic, topographic, anthropogenic and ecological factors interact to drive hyporheic exchange flows at large scales. Further evidence is needed to link hyporheic exchange flows across scales. This review aims to conceptualize interacting factors at catchment, valley and reach scales that control spatial and temporal variations in hyporheic exchange flows. The implications of these drivers are discussed for each scale, and co-occurrences across scale are highlighted in a case of study. By using a multi-scale perspective, this review connects field observations and modelling studies to identify broad and general patterns of HEF in different catchments. This multi-scale perspective is useful to devise approaches to interpret hyporheic exchange across multiscale heterogeneities, to infer scaling relationships, and to inform watershed management decisions.

Keywords: hyporheic zone, catchment, valley, reach, driving factors

\section{Introduction}

Hyporheic zones (HZ) are unique components of river systems that underpin fundamental stream ecosystem functions (Orghidan, 1959; Brunke and Gonser, 1997; Boulton et al., 1998; Krause et al., 2011a; Merill and Tonjes, 2014; Boano et al., 2014; Harvey and Gooseff, 2015; Ward, 2016). At the interface between rivers and aquifers, hyporheic zones are defined by the interchange of surface and ground waters through hyporheic exchange flows (HEF), and have been recognized to be important for vertical and lateral connections of rivers with floodplains and underlying aquifers (Elliott and Brooks, 1997; Malard et al., 2002; Boano et al., 2006; Wondzell, 2006; Wörman et al., 2006; Cardenas and Wilson, 2007; Gooseff et al., 2007; Lautz et al., 2010). HEF plays a significant role in biogeochemical cycling (e.g., carbon and nutrient availability and transformation), ecological food webs, and 
Hydrol. Earth Syst. Sci. Discuss., doi:10.5194/hess-2016-683, 2017

Manuscript under review for journal Hydrol. Earth Syst. Sci.

Published: 9 January 2017

(c) Author(s) 2017. CC-BY 3.0 License.

habitat for diverse organisms (Brunke and Gonser, 1997; Boulton et al., 1998; Krause et al., 2011a; Merill and Tonjes, 2014; Ward, 2016).

HEF is driven by hydrostatic and hydrodynamic forces within rivers and floodplains (Elliott and Brooks, 1997; Packman and

Brooks, 2001; Cardenas et al., 2004; Boano et al., 2007, 2014), but the hierarchical and heterogeneous nature of these systems creates complex spatial and temporal patterns of exchange flows. There are strong gradients of structure and flow conditions formed by the drainage network (Gomez-Velez and Harvey, 2014) and results from i) the recognition of the temporal and spatial scales of the stream system as a continuum from upstream to downstream, vertically, and laterally (i.e. river continuum and spiraling concepts), ii) complex geomorphological structures as consequences of long-term erosion and deposition processes (armoring, bedforms, bars and other lateral variability within channels, braiding, meanders, floodplain deposits etc.) and, iii) temporal variability changing from upstream to downstream and lateral connectivity (i.e. flood spates, overbank flows, etc.) (Hynes, 1975; Vannote et al., 1980; Newbold et al., 1981, 1982; Minshall et al., 1985) (Fig.1). Therefore, understanding and predicting HEF dynamics requires a consideration of the hydrological, geomorphological and ecological processes operating across a spectrum of spatial and temporal scales (Ward 2016).

15 Previous reviews have furthered our understanding of hyporheic zone functioning at reach- and bedform-scales (Brunke and Gonser, 1997; Boulton et al., 1998; Krause et al., 2011a; Boano et al., 2014; Merill and Tonjes, 2014; Harvey and Gooseff, 2015; Ward, 2016). However, lack of a formal approach for scaling hyporheic flows and rarity of multi-scale studies means that knowledge of spatial and temporal variation of HEF across scales remains fragmentary.

In this review, we propose a hierarchical approach to hyporheic exchange based on physical processes, with HEF related to hydrogeologic and hydrological factors at the catchment, floodplain and river reach scales (Fig. 2). Through a critical evaluation of the literature from a range of disciplines (e.g., catchment hydrology, groundwater hydrology, fluvial geomorphology, river hydraulics), we outline how hydroclimatic, hydrogeologic, topographic, anthropogenic, and ecosystem factors influence the partitioning of water flows to generate (or not) HEF in river banks, beds, and floodplains. Based on these results, we attempt to systematically link the scale dependent-factors controlling HEF across spatial scales. In the process, we emphasize the importance of the landscape scale, which has not been considered in previous studies, and synthesize how processes interact in space and time, across scales and what are the consequences.

The review is structured around spatial scales arranged according to a cascade of processes starting from origin and distribution partitioning of water at catchment scale (Section 3) to its delivery from valley scale (Section 4) down to the river channel (Section 5) (Fig. 3). This structure aims to express the hierarchical pattern of hyporheic exchange flows across scales to explore its spatial relationship with four main drivers. In fact the discussion of processes at each spatial scale is classified into four types of drivers: hydroclimatic, hydrogeological, topographical, anthropogenic and ecological (Fig. 2). For each scale, a brief outline of the relevant factors driving the HEF is given, followed by a detailed description of how each class of characteristics 
Hydrol. Earth Syst. Sci. Discuss., doi:10.5194/hess-2016-683, 2017

Manuscript under review for journal Hydrol. Earth Syst. Sci.

Published: 9 January 2017

(c) Author(s) 2017. CC-BY 3.0 License.

influences spatial and temporal variation of exchange (Table 1). Additionally we present a case study at reach scale to illustrate how the conceptual framework can be applied (Section 6).

\section{Concepts and terminology}

The term "hyporheic zone" has been defined variously in the literature, and some confusion still exists within the wider research community about the extent and nature of the HZ. To help facilitate the integration and presentation of results from a large number of studies spanning a range of disciplines in this review, we will use a simplified and standardized terminology for the $\mathrm{HZ}$ and hyporheic exchange flows (HEF).

Herein, we follow the "flexible" definition of HZ, as reported by Ward (2016): “...saturated subsurface including flow paths that originate from and return to surface water where interactions occur within a temporal scale relevant to the process of interest, and processes of interest occur continuously from the stream-subsurface interface to the hyporheic-groundwater continuum." In terms of hyporheic exchange, we recognize that a continuum of hyporheic flow paths is associated with different hydrologic residence times (Worman et al., 2007, Cardenas, 2008b, Boano et al., 2014), and that residence time is important for biogeochemical processes and ecological investigations (e.g., metabolism, nitrification, and denitrification). However, for the purpose of this review we will not investigate biogeochemical and ecological processes, and will present hyporheic flow as exchange flux, i.e. HEF, rather than residence time.

By definition, the HEF (Ward, 2016) is related to large-scale groundwater surface-water exchange (GSE), but the terms are not synonymous. HEF is an interchange between surface and subsurface waters, whereas GSE is primarily a unidirectional flow. As shown in modelling studies (Cardenas and Wilson, 2006; Sawyer and Cardenas, 2009; Stonedahl et al., 2012), HEF and GSE can act in opposite direction. For example, a reach under losing condition due to groundwater recharge can have superimposed HEF occurring simultaneously (Stonedahl et al., 2012; Fox et al., 2014). Consequently, in this review we report large-scale GSE in addition to HEF (Fig. 2 and 3). We also refer to hyporheic "extent" when the HZ expands or contracts in the horizontal ("lateral extent") or vertical ("vertical extent") directions, respectively. Finally, we use the term "bank storage exchange" (Pinder and Sauer, 1971) for the case where lateral HEF between the river and floodplain is induced by the rise and fall of river water levels (Cranswick and Cook, 2015).

\section{Catchment}

The catchment is a topographically delimited area drained by a river and its tributaries, and hydrological processes operating at this scale determine the quantity, timing and partitioning of water flows (Grabowski et al., 2014). The catchment scale is a fundamental component of hierarchical studies of river systems, but few studies have investigated the connections between 
Hydrol. Earth Syst. Sci. Discuss., doi:10.5194/hess-2016-683, 2017

Manuscript under review for journal Hydrol. Earth Syst. Sci.

Published: 9 January 2017

(c) Author(s) 2017. CC-BY 3.0 License.

factors at this scale and hyporheic exchange flows (Wroblicky et al., 1998; Boano et al. 2008; Boano et al. 2009; Fox et al., 2014). This section explores how catchment-scale factors could influence hyporheic exchange flows at smaller spatial scales. We start with the input of water to the catchment (hydroclimate), and then outline how characteristics affect the partitioning of flows and transport of water over (topography and land management) and under (hydrogeology) the land surface.

\subsection{Hydrological factors: hydroclimate}

Hydrological factors such as precipitation and temperature have highly variable distribution in both quantity and timing, and are controlled by regional climate and local topography and land-surface characteristics. This variability influences groundwaterrecharge (i.e. infiltration) processes and hyporheic exchange flows (Dragoni and Sukhija, 2008). Hyporheic zones and flows have been observed to change seasonally in response to wetter and drier catchment cycles and associated groundwater fluctuations (Section 4.1) (Wondzell and Swanson, 1996; Storey et al., 2003; Ward et al., 2012; Voltz et al., 2013; Azinheira et al., 2014; Malzone et al., 2015). However, because limited research has been conducted on this topic at catchment scale, we must infer possible connections to HEF from more general catchment hydrology studies. We know that hydroclimate is the primary determinant of the quantity of water landing on and flowing through a catchment. It also affects the partitioning of flow pathways (i.e. surface vs. subsurface) through its impacts on soil properties (e.g., soil moisture), and influences both the average stream/aquifer levels. As water level differentials is one of the major drivers of hyporheic exchange, hydroclimate's impacts on river and aquifer levels should have significant consequences on the magnitude of HEF (Toth, 1963; Winter, 1998; Bis, 2000; Cardenas and Wilson, 2007; Boano et al., 2008). . In fact, precipitations cause changes in the spatial structure of the $\mathrm{HZ}$ by variating river and groundwater levels, and HEF is expected to change accordingly with the oscillation of hydraulic heads and larger-scale patterns of groundwater recharge and discharge (Section 4.1) (Wondzell, 2006). At catchment scale, quick increases of the groundwater table during a precipitation event promote continuous groundwater discharge (Sawyer et al., 2014) and in turn changes hyporheic bank storage (Brunke and Gonser, 1997). After precipitation, stream levels normally rise faster than the groundwater table thus leading to dynamic storage of water in stream banks and floodplains (Krause, 2007; Gulley et al., 2011). Bank storage is expected to be larger when stream flows are enhanced (i.e. after precipitation) and where sediment hydraulic conductivity is high (i.e. mountainous setting) (Wroblicky et al., 1998). In headwater catchments, hydrologic and geomorphic processes are strongly coupled: confined and steep valleys respond rapidly to rainfall because of their small storage capacity (Woods et al., 1995; Gomi et al., 2002), so precipitation and snowmelt inputs control river base flow, lateral inflows from adjacent hillslopes, and overland flow. Precipitation-catchment interactions thus drive pathways of water motion through the hillside to the stream, resulting in different responses in extent and magnitude of hyporheic exchange flows (Wondzell, 2006). Precipitation also controls the runoff regime (Section 4.1), and thereby affects the hyporheic extent on the scale of hours to days (Brunke and Gonser, 1997; Malzone et al., 2015, 2016).

The spatial variability of precipitation influences not only large-scale hydrological exchanges at catchment scale owing catchment drying and wetting, but also valley scale connectivity between lowland and upland streams (Section 4.1), and flow 
Hydrol. Earth Syst. Sci. Discuss., doi:10.5194/hess-2016-683, 2017

distributions in reaches (Brunke and Gonser, 1997; Winter, 1998; Tetzlaff et al., 2011).In fact, the magnitude of the impact of climate on catchment water resources will depend on several fundamental controls: type of bedrock, which in turns determine aquifers typology; erosion and deposition patterns that controls surface topography and the distribution of fluvial and alluvial deposits; land use and land cover (Tanakamaru and Kadoya, 1993; Bultot et al., 1994; Arnell and Reynard, 1996; Hlavcova and Cunderlik, 1998). The effect of spatio-temporal variability of the above factors on hydrological states and fluxes is discussed below.

\subsection{Topographical factors}

At catchment scale, topographical gradient and catchment area have key roles on controlling deep groundwater flows (Toth, 1963; Winter, 1998; Wörman et al., 2006; Jencso and McGlynn, 2011), overland flow, meso-scale topography (landforms and river planforms: Section 4), and small-scale topography (roughness on the order of $\mathrm{cm}$ to m: Section 5) (Sawyer et al., 2015, Caruso et al., 2016). Consequentially, the spatial complexity of HEF at smaller scales is not only linked to the geomorphological characteristic of the reach and valley, but also the topographical structure of the whole catchment.

Local, intermediate and regional flows recharge and discharge from and to the river, according to the amplitude of the topographical variations between discharge and recharge areas (Freeze and Witherspoon, 1967; Hiscock, 2007). The topographic slope defines the direction of flow by creating discontinuities and localized groundwater flow paths (Toth, 1963; Wolock et al., 2004; Devito and Smerdon, 2005; Mitchell-Bruker and Haitjema, 2005). Spectral analysis has demonstrated the fractal nature of land topography and the associated fractal distribution of recharge and discharge areas and of subsurface flows (Wörman et al., 2006, 2007). Therefore, head variations due to surface topography are often used as indicators of subsurface flow (Wörman et al., 2006; Jencso et al., 2009; Jencso and McGlynn, 2011, Caruso et al., 2016). Recent publications have shown how surface topography and the complexity of the water table induce spatial variations in groundwater discharge, which in turns drive spatial variation of HEF at smaller scales (Caruso et al., 2016), and add further complexities to the heterogeneous distribution of subsurface flows as consequence of geographic, geologic and hydrologic conditions (Gleeson et al., 2016).

Together with topographic gradient, catchment area and channel network structure also influence the magnitude of hyporheic exchange flows by providing a first order control of water inputs and flow processes at large scale (Laudon et al., 2007; McGuire and McDonnell, 2010). However the spatial and temporal variability in surface input from hillslopes to stream networks causes a high degree of variability in HEF across stream reaches (McGlynn et al., 2003). Headwater riparian zones determine catchment riparian buffering capacity and the ratio of hillslope areas and riparian vegetation on the catchment area can potentially inform about the buffering capacity of the catchment in runoff conditions or predominant areas of erosion and deposition (McGlynn et al., 2003). To date, the effect of the catchment area has been mainly considered at reach scale by assuming that catchments with larger surface areas have greater hyporheic exchange fluxes (i.e. greater variation in water stage 
Hydrol. Earth Syst. Sci. Discuss., doi:10.5194/hess-2016-683, 2017

Manuscript under review for journal Hydrol. Earth Syst. Sci.

Published: 9 January 2017

(c) Author(s) 2017. CC-BY 3.0 License.

contribute on average to greater hyporheic fluxes) (Harvey and Wagner, 2000; Laenen and Bencala, 2001). Few direct observations are available to support or refute this assumption, but Anderson et al., (2005) observed patterns of upwelling and downwelling within reaches decrease with decreasing water surface concavity and increasing catchment area.

\subsection{Hydrogeological factors: bedrock and aquifer types}

Geology affects both the distribution of groundwater in aquifers and surface-groundwater exchange flows. Water discharged from bedrock and alluvial aquifers significantly contribute to river baseflow (Larkin and Sharp, 1992) and catchment outflow (Käser et al., 2014; Käser and Hunkeler, 2016). From reach to regional scale, the spatial variability of GSE and HEF in the river network is determined by aquifer geometry and geological heterogeneity, which influence both subsurface water inputs to streams and the distribution and magnitude of hydraulic conductivities within the channel and floodplain (Morrice et al., 1997; Winter, 1998; Woessner, 2000; Hiscock, 2007; Krause et al., 2011b; Angermann et al., 2012a; Fox et al., 2014; Gomez-Velez and Harvey, 2014). This section presents how geologic properties and heterogeneity of rock and types of aquifers (rock types and confinement) impact the spatio-temporal variability of HEF and groundwater flow.

The hydrogeological properties of the bedrock and superficial deposits dictate the presence and behavior of an aquifer, In particular, characteristics such as porosity and grain size determine if and how subsurface water will flow (i.e. permeability and transmissivity)while the spatial distribution of bedrock and alluvial/colluvial deposits determine how flows are realized (Winter, 1998). By determining the amount of water the rock can retain under saturation, porosity controls the efficiency of groundwater recharge processes and precipitation infiltration through the rock (Sear et al., 1999). Both primary porosity (i.e. pores) and secondary porosity (i.e. fractures) determine the permeability of the material and thus the movement of ground water into and out of adjacent aquifers. Particularly important for groundwater hydrology are consolidated and semiconsolidated deposits of limestone, dolomite, shale, siltstone, sandstone, and conglomerate that include both pores and fractures and are characterized by primary and secondary porosity.

Bedrock geology is a simple descriptor of potential GSE and HEF, indeed, the distribution of distinctive lithologic formations in the aquifer promotes varying ground-surface water interactions (Morrice et al., 1997) and the occurrence of high-permeability granular facies and highly weathered and faulted environments (i.e. faults and fissures/cracks) yields preferential GSE. Rock outcrops can cause large surface-water exchanges over a wide range of scales (both upwelling and downwelling) (Section 4.2.2). Carbonatic (e.g., limestone and dolomite) aquifers can be very efficient for groundwater recharge because of fractures and secondary porosity that allow precipitation to easily infiltrate through the rock (Sear et al., 1999). Sandstone and siltstone rocks, characterizing siliceous aquifers present intergranular porosity and fractures which contributes to their transmissivity (Hiscock, 2007). In sandstone environments, given the low to moderate primary intrinsic permeability (hydraulic conductivity 
Hydrol. Earth Syst. Sci. Discuss., doi:10.5194/hess-2016-683, 2017

sandstone-siltstone catchment, Morrice et al. (1997) observed the lowest values of groundwater storage than in gneiss and volcanic tuff catchments while bed with poorly sorted cobbles and boulders in a granitic catchment presented the highest values. Often in granitic environments, the increase of sediment grain size allows more water to be exchanged between the stream and aquifer, and increases the opportunity for water storage in the subsurface (Morrice et al., 1997). Igneous and metamorphic rocks are characterized by shallow fracture systems, thus almost all groundwater flow in the sufsurface takes place through cracks and fractures in the rocks. This type of flow allows groundwater movement along short flow paths and possibly shorter residence times (Morrice et al., 1997). Chalk environments for example are dominated by groundwater flow with a narrow range of high Baseflow index (BFI) values and high Q95 (the 5 percentile flow) values (Sear et al., 1999, Table III) (Section 4.1). Hyporheic studies in chalk catchments have shown the importance of groundwater in supporting surfacesubsurface exchange, although vertical hyporheic exchange in these systems is often restricted by low-conductivity superficial deposits (Pretty et al., 2006; Allen et al.1997). Conversely, hard limestone such as carboniferous series, have much wider range of BFI but a lower Q95 reflecting the contribution of a fractured flow type (Sear et al., 1999, Table III). Gneiss basins have high hydraulic conductivity and strong interaction between the stream and the storage zone with long residence times (Morrice et al., 1997).

15 In addition to the characteristic of the rocks, groundwater occurs in aquifers under two different conditions: confined and unconfined. In both unconfined and confined calcareous aquifers, GSE is facilitated by the presence of conduit systems, porosity and permeability of the media (e.g., granitic environment) (Brunke and Gonser, 1997). Confined aquifers are separated from the surface by aquitards with low hydraulic conductivities, which limit or prevent ground-surface water exchange with these aquifers (Winter, 1998). If the confinement is due to the presence of near-surface bedrock, the lack of alluvium limits vertical HE flows (Kasahara and Wondzell, 2003; Buffington and Tonina, 2009). Indeed, Gurnell et al. (2016) described GFE patterns with consideration of the permeability of confining layers, with GSE being prevented or limited to local interactions in confined bedrock and colluvial channels or in confined alluvial channels depending on the local structure of the local sediment (e.g., coarse or fine particles) and to rock structure (e.g., continuous or discontinuous confinement) (Gurnell et al., 2016, Table 7.5). In unconfined aquifers, generally groundwater is easily conveyed in all directions leading to high opportunity for both vertical and lateral hydraulic exchange (Winter, 1998), although in the case of unconfined alluvial channels GSE can be prevented or limited to local interactions depending on local sediment (e.g., coarse or fine particle size) (Gurnell et al., 2016, Table 7.5).

\subsection{Anthropogenic factors - land management impacts on surface hydrology}

The significant impact of land management on the quality (i.e. sediment and nutrient inputs) and quantity (i.e. discharge, evapotranspiration (ET)) of groundwater and surface water (Rodriguez-Iturbe, 2000; Strauch et al., 2013; Kalantari et al., 2014; McGonigle et al., 2014) is clear in the literature. Building upon this, we contend that land use at catchment scale strongly 
Hydrol. Earth Syst. Sci. Discuss., doi:10.5194/hess-2016-683, 2017

Manuscript under review for journal Hydrol. Earth Syst. Sci.

Published: 9 January 2017

(c) Author(s) 2017. CC-BY 3.0 License.

influence the spatial and temporal dynamics of the HEF (Ryan et al., 2010) via modification of stream flow regimes (Lee et al., 2003, Gallo et al., 2015) .

The direct effect of agriculture practices on flow is linked to the evapotranspiration regime, to the geology of the site and to the local geology, because all of these aspects affect surface runoff, infiltration and water residence time, and soil compaction (Fohrer et al., 2001, Holman et al., 2003; Biro' et al., 2007; Carrillo-Rivera et al 2008; Cho et al., 2009; Kalantari et al., 2014; Mishra et al., 2014; Santos et al., 2015; Owuor et al., 2016). Indeed, hydrological simulations suggest direct connections between water balance and changes in land use: reduction of evapotranspiration on barley field, impact on the temporal dynamics of surface runoff with consequent increase of baseflow and total stream flow (Section 4.1) (Fohrer et al., 2001). Changes in runoff ratio have been observed with crop conversion and the expansion of artificial drainage, owing to changes in both ET and water residence time on the landscape (Jalota et al., 2006; Singh et al., 2009; Kumar et al., 2009; Mizuba and Hammel, 2001; Wang and Hejazi , 2011; Schottler et al., 2014). Tillage practices (i.e. tillage, conservation tillage, contour farming, no tillage) directly impact surface runoff, erosion, and HEF. For example, conservation tillage and contour farming help reducing runoff of about 15\% when compared to straight tillage (Liu et al, 2003; Greer et al., 2006; Singh et al., 2009) while no-tillage practices show higher infiltration and lower ET (Golmohammadi et al., 2016).

15 In the end, agricultural activities also results in large and small scale micro-forms depending on the method and direction of tillage used: from ridges and furrows (Szabó, 2006; Buis and Veldkamp, 2008), ditches, ridges and berms (Li et al., 2009; Vieira and Dabney, 2011) to saucer shaped depressions (Darboux et al., 2002; Pásztor et al., 2006; Li et al., 2009). These local scales morphological changes together with presence/absence of forest, wetlands or impervious surfaces significantly the hydrologic regime of the catchment and the observed HEF (Ryan et al., 2010).

\section{Valley}

The valley scale is the connection between hillslope to river channels, and includes characteristics that relate to the valley and floodplain, river segment, river flows and levels, and natural riparian vegetation. At this scale, hydrological factors (e.g., groundwater discharge and river runoff) control the distribution of hydrodynamic forces and river energy; while hydrogeological and topographical ones (e.g., superficial deposits, valley settings, valley gradient, planform mobility and sinuosity) impact on spatial variations of HEF in direction and magnitude (Wondzell, 2011; Marzadri et al., 2014). In the next sections we discuss how temporal and spatial variations in groundwater and river levels influence the extent of the HZ and HEF. Within the context of groundwater dynamics, we accept that HEF takes place in both losing and gaining stream conditions (Harvey and Bencala, 1993; Harvey et al., 2003; Stonedahl et al., 2012; Fox et al., 2014) although the way it occurs is a function of regional groundwater and catchment characteristics interacting with smaller-scale reach properties (Larkin and Sharp, 1992; Wondzell and Gooseff, 2013). 
Hydrol. Earth Syst. Sci. Discuss., doi:10.5194/hess-2016-683, 2017

Manuscript under review for journal Hydrol. Earth Syst. Sci.

Published: 9 January 2017

(c) Author(s) 2017. CC-BY 3.0 License.

\subsection{Hydrological factors: groundwater dynamics}

HEF is related to groundwater dynamics because the distribution of hydraulic head over stream channel boundaries is influenced by both geomorphological structures and groundwater flows (Krause et al., 2012).

The effect of groundwater input to the hyporheic zone and patterns of gaining and losing condition varies strongly and is difficult to generalize given the diverse geomorphology of river valleys (Wondzell and Gooseff, 2013). Small-scale HEF have been observed in both strongly gaining and losing conditions (Wondzell and Swanson, 1996; Cardenas and Wilson, 2007; Payn et al., 2009), but little information is available on these effects at valley scale. Numerical simulations suggest that a decrease of HEF in magnitude is more likely to occur in straight channels than in meandering channels, where losing conditions confines hyporheic flow to near the bend apex (Cardenas, 2009b).

During dry conditions, groundwater inputs to the $\mathrm{HZ}$ are generally low and have minor effects on exchange; increasing groundwater input to the channel affects the extent and magnitude of exchange (Wondzell and Gooseff, 2013). Further, river water losses to adjacent aquifers during loosing conditions limit the return flows to the stream (Cardenas, 2009a). Conversely, during strongly gaining conditions, steep streamward hydrologic gradients limit the extent of the HZ (Harvey and Bencala, 1993; Wroblicky et al., 1998; Storey et al., 2003; Malcolm et al., 2005; Cardenas and Wilson, 2007; Cardenas, 2009a, Wondzell and Gosner, 2013; Fox et al., 2015). As groundwater discharge increases, the HZ contracts (Gilbert et al., 1990; Vervier et al., 1992; White, 1993; Boulton et al., 1998; Boano et al., 2008) and hyporheic flow residence time decreases (Wroblicky et al., 1998). Harvey and Bencala (1993); Wroblicky et al. (1998) and Storey et al. (2003), observed that an increase of groundwater inflows from adjacent hillslopes can reverse head gradients along the stream margin, and decrease both the extent of the hyporheic zone and the volume of the hyporheic exchange flow. Further, the hyporheic depth can be restricted by increasing groundwater flow towards the stream when surface runoff is limited and local rainwater recharges groundwater (Malard et al., 2002).

Event or seasonal variations in flow regimes that vary ground- or surface-water hydraulic heads will in turn alter HEF. The temporal aspect of river flow regime at valley scale is an important linkage to reach hyporheic flows and runoff processes at catchment scale, in particular when local groundwater recharge and streamflow are asynchronous (e.g., Section 3.1 and snow catchment). The hyporheic zone has been observed to expand and contract with depth in response to seasonal and event-based water table fluctuations (i.e., baseflow conditions, spring-summer and summer-fall transition) (Malzone et al., 2015). Simulations suggest that the hyporheic zone expands as gradients between surface water and the riparian water table decrease (Malzone et al., 2015, 2016). Also, floods increase both the extent of the $\mathrm{HZ}$ and the hyporheic residence time (Wondzell and Swanson, 1999; Wondzell et al., 2010) due to increases in stream stage and velocity that increase the exchange rate during the flood and drive water farther from the channel (Malcolm et al., 2004; Bhaskar et al., 2012). This is particularly the case for streams having annually stable water tables (Malzone et al., 2016). Several studies have shown that the HZ expands after storms, and that hyporheic flow paths revert or shorten during periods of stream recharge (groundwater discharge) that decrease 
Hydrol. Earth Syst. Sci. Discuss., doi:10.5194/hess-2016-683, 2017

gradients between the stream and the riparian water table (Hakenkamp et al., 1993; Vervier et al., 1992; White, 1993; Soulsby et al., 2001; Bhaskar et al., 2012; Ward et al., 2012; Malzone et al., 2015).

Finally, HEF is especially affected by seasonal changes in groundwater discharge and recharge according to longitudinal valley gradients and topographic complexity (Section 4.2); catchment precipitation regimes (Jones et al., 2008) (Section 3.1); aquifer, floodplain, and channel stratigraphy; and the riparian biome (i.e. vegetation) (Section 4.5.1) (Poole et al., 2006; Wondzell, 2006; Jones et al., 2008; Ward et al., 2012; Wondzell and Gooseff, 2013; Boano et al., 2014).

\subsection{Topographical variables}

Topographic roughness at all scales drive hyporheic exchange, causing nested flow paths (Worman et al., 2007; Cardenas, 2008; Buffington and Tonina, 2009; Ward et al., 2012) (Fig. 8). This section introduces how valley setting controls the linkage between hillslope and channel domains in lowland and uplands environments and in turn the differences in the development of hyporheic flows between steeper constrained and lower flatter unconstrained valleys (Jones et al., 2008). Lithological characteristic of the valley appears also in this section as geology dictates both the current flow configuration and the spatial pattern down-valley.

\subsubsection{Valley setting (lowland and upland)}

Longitudinal valley gradients create hydrostatic head gradients that influence water moving cross and down valley and thus the HEF (Harvey and Bencala, 1993). During low precipitation periods, some alluvial floodplains channels and wetlands are fed by hyporheic flows, and the magnitude of hyporheic exchange is related to the possibility of hyporheic flow to move down valley (Stanford and Ward, 1993). Ward et al. (2012) reports both positive and negative relationships between hyporheic zone and down-valley gradients near hillslopes, suggesting that cross-valley and vertical hydraulic gradients control the HEF. Valley-floor morphology therefore drives hyporheic exchange in both high- and low-gradient streams.

In higher-gradient valleys, groundwater contributes to stream discharge along bedrock outcrops, spring-brooks and canyons which delimit the floodplain (Stanford and Ward, 1993). In this setting, the flow is predominantly down valley and spatial variations of hydraulic gradients are paired with changes in cross-sectional areas of the valley (Section 4.2.2) and with the hydrodynamic head gradients generated by morphological features within the stream channel (e.g., bedforms, Section 5.1) to induce water downwelling into the HZ (Cardenas et al., 2004, Wondzell, 2012).

The influence of groundwater input in lowland valleys differs from upland ones due to channel morphology, streambed sediments, and magnitude of anthropogenic impact. Lateral inputs of groundwater coupled with changes in stream stage substantially reduce both the extent and the magnitude of HEF (Stanford and Ward, 1993), although few studies have related valley-scale gradients to hyporheic flowpaths directly. Hyporheic exchange in these systems is mainly driven by advective 
Hydrol. Earth Syst. Sci. Discuss., doi:10.5194/hess-2016-683, 2017

flow induced by interactions between the longitudinal elevation profile of the stream, within-channel bedforms, and streambed hydraulic conductivity (Fig. 6) (Krause et al., 2007).

Strong differences are expected between steep upland and lowland areas, when considering depth to bedrock: shallow bedrock and deep bedrock in upland and lowland settings respectively. As depth-to-bedrock increases, the hyporheic flow is less vertically constrained and therefore increases (Packman et al., 2001; Hester and Doyle, 2008). Indeed, variations of water surface profile due to longitudinal variation of bed depth deposits and irregularities of bedrock (Section 3.3) affect upwelling and downwelling of hyporheic water (Anderson et al., 2005). The changes in HEF with bed concavity and convexity are expected to be different in steep and low gradient settings (Anderson et al., 2005); due to the steepness of the water surface slopes (Anderson et al., 2005). Conversely, at channel unit scale, the effect of bed depth will especially affect flows over bedforms, where enhanced HEF results from variation of dynamic head via shallow subsurface alone (Section 5).

\subsubsection{Valley type}

Valley-floor and channel morphology control HEF in different ways depending on the valley type, which can be related generally to stream order because of covariations between channel constraints, channel planform morphology, and bedform sequences (Stonedahl et al., 2013; Kasahara and Wondzell, 2003) (Fig. 8). Several studies have linked HEF to valley confinement; hyporheic residence time is reduced, $\mathrm{HZ}$ depth restricted and hyporheic exchange flows low in highly confined valleys (D'angelo et al., 1993; Stanford and Ward, 1993; Wright et al., 2005; Buffington and Tonina, 2009) (Table 2). While the spatial variation of valley confinement depends on the specific hydrogeologic history (uplift, precipitation, glaciation etc.) and geology of the catchment, but confined valleys are more commonly found in lower order streams in the headwaters.

While GSE and HEF are limited in confined valleys, bedrock fractures and fissures may allow some hyporheic exchange, depending on their degree of connectivity with the aquifer (i.e. bedrock and colluvial channels in straight and sinuous planforms) (Gurnell et al., 2016). Bedrock outcrops at valley margins can have opposing impacts on HEF. On one hand, they can limit the infiltration of the stream water into the subsurface and restrict the hyporheic zone (Kasahara and Wondzell, 2003). Indeed, bedrock outcrops can constrain valleys where steep positive vertical hydraulic gradients results from discontinuities of superficial deposits permeability and shallow bedrock (Ibrahim et al., 2010). In this case the HEF can be limited to superficial layers of the riverbed. On the other hand, the irregularities of bedrock projections favor changes in the alluvium volume (Buffington and Tonina, 2009), thus driving stronger hyporheic exchange from the subsurface to the stream and preventing deeper GSE. In fact, the interchange between bedrock and alluvial valleys favor HEF, because of increased downwelling and upwelling where a thin layer of alluvial deposits overlies shallow bedrock (Wondzell, 2012).

Conversely, in unconfined valleys, floodplain sediments typically represent a mosaic of coarse and fine sediments that channel adjustment over time (e.g., migration and avulsion) (Nanson and Croke, 1992) (Table 2). Buffington and Tonina 
Hydrol. Earth Syst. Sci. Discuss., doi:10.5194/hess-2016-683, 2017

Manuscript under review for journal Hydrol. Earth Syst. Sci.

Published: 9 January 2017

(c) Author(s) 2017. CC-BY 3.0 License.

(2009) classified channel types by examining how mesoforms generate hydro-dynamic pressure variations and drive hyporheic exchange (Fig. 4). Generally, unconfined channels have smaller vertical hydraulic gradients and discharges than confined channels, caused by the lower channel gradients and by the heterogeneity of sedimentary deposits (Ibrahim et al., 2010). In unconfined river segments, reach scale factors are of major importance but still can interact with flows more widely across the floodplain. In these channels, channel bedforms, like riffles, can strongly promote hyporheic fluxes in the riverbed. For example, the presence of pool-riffle sequences can have a big role in developing cross-valley head gradients from differences in overall longitudinal gradients which therefore increase overall valley gradients and enhance the HE (Kasahara and Wondzell, 2003). We integrate available information (e.g., underlying geology, in-channel sediment, valley confinement) at valley and reach scales in Table 3. Kasahara and Wondzell (2003) simulated hyporheic exchange fluxes and estimated the effect of channel morphological features on HZ extent and HEF suggesting that HE responds differently to bedrock-constrained site and unconstrained ones. Their results reflect changes in the amount and residence time of the hyporheic exchange (Kasahara and Wondzell, 2003; Hester and Doyle, 2008).

While HEF can be strongly promoted by bed configuration (e.g., riffles and pools) and forms (e.g., bars), and this will be discussed in more detail in Section 5.1 and 6.2, valley type is correlated to more broadly to GSE and HEF due to sediment sizes and the topographic variability of the channel.

\subsection{Hydrogeological factors in river and floodplain type}

Similar to the influence of bedrock geology at the catchment scale (Section 3.2), superficial sediments can significantly impact GSE via the HZ (Krause et al., 2012) and in turn influence overall hyporheic exchange flows and storage (e.g., presence of low conductivity streambed strata, Bencala, 1984; Harvey and Wagner, 2000; Buffington and Tonina, 2009; Angermann et al., 2012a; Stonedahl et al., 2013). At this scale, bed material caliber (grain size) expresses internal channelforming mechanisms framed in the degree of confinement of the valley (Table 2). In fact, differences in superficial deposits result from longitudinal, spatial and temporal variation of river flows and levels.

In river segments dominated by gravel beds, such as in confined high energy braided rivers, the hydraulic conductivity is generally high but also highly variable because it depends on the sorting of sediments in the floodplain (and on the amount of silt and clay present (e.g., wandering floodplains) (Table 2 and Fig. 4). Highly permeable riverbed sediments allow surface water to penetrate easily into the HZ, causing vertical hydraulic gradients (VHG) to change strongly with local sediment permeability (Vaux, 1968; White, 1993; Wroblicky et al., 1998; Packman et al., 2003). For similar reasons, the thickness of superficial deposits controls the extent and rate of hyporheic exchange (Buffington and Montgomery, 1999; Anderson et al., 2005; Tonina and Buffington, 2011). Indeed, Ellis et al. (2007) found that spatial variations in the thickness of fluvialalluvial deposits increased local gradients around clay lenses, therefore creating locally confined conditions (Ellis et al., , 2007). 
Hydrol. Earth Syst. Sci. Discuss., doi:10.5194/hess-2016-683, 2017

Braided channels can occur across a range of valley slopes, depending on the grain size of the bed material in transport and present either a pool-riffle morphology or a bar-riffle morphology (Gurnell et al., 2016). Due to multiple channels, braided rivers tend to be very dynamic leading to strong temporal variability of hyporheic exchange and associated aquatic habitats (Ward and Stanford, 1995; Malard et al., 2002). Bed materials range in fact from large cobble to sand, depending on the caliber of the sediment supply and local valley slope. The lateral channel migration and the high permeability of sediments allow varying residence time responses accordingly to finer or coarser deposits and hyporheic exchange processes occurring vertically and laterally (Brunke and Gonser, 1997) (Fig. 4). Indeed, typical of braided rivers is the transversal exchange between multiple channels (Fig. 4), governed longitudinal gradients between channels (Fig. 4). The steep head gradients between channels create cross-valley head gradient that control the location and direction of flow paths through the HZ. The transversal exchange evolves with migration and river sediment transports processes (Stonedahal et al., 2010; Boano et al., 2006; Kasahara and Wondzell 2003).

In sandy river segments, which are typical of sinuous and medium energy meandering floodplains, the HEF is also usually driven by advection processes, which are greater than diffusive transport by two or more orders of magnitude (Savant et al., 1987; Larkin and Sharp, 1992; Elliott and Brooks, 1997). This type of floodplain also typically presents vertically accreted fine sediments (silt and clay). These local low-permeability units and thick sequences of unconsolidated deposits are more compact and less permeable with depth (Winter, 1998; David et al., 2006 ) thus they are characterized by localized groundwater flows and restricted HEF (Angermann et al., 2012a; Krause et al., 2012; Stonedahl et al., 2012). In lowland settings with abundant fine sediment load, when a reduction of groundwater up-welling due to low sediment conductivity layers occurs, surface water downwells and horizontal hyporheic flow is induced into shallow streambed sediments above low conductivity strata (Angermann et al., 2012b; Stonedahl et al., 2012).

Finally, another characteristic to take into account, when reporting the effects of hydrogeological factors on river and floodplain types is sinuosity. Sinuosity is often used as a measure of channel complexity and has been seen to be directly correlated to lateral hyporheic exchange in meander bends, and in parafluvial zone beneath the streambanks (Holmes et al., 1996; Wroblicky et al., 1998; Boano et al., 2006; Cardenas, 2008a; Kiel and Cardenas, 2014). Sinuosity influences the amount of water exchanged within a river segment (Brunke and Gonser, 1997) because changes in streambed plan form can alter the path of subsurface intra-meander ecosystem, including the HEF (Boano et al., 2006, 2008; Cardenas, 2009a; Gomez et al., 2012; Han and Endreny, 2013). High sinuosity rivers types (e.g., multi-thread or single/sinuous meandering) are less prone to a reduction of the hyporheic area with depth being able to maintain the HZ under largely losing and gaining conditions (Cardenas, 2009a) (Section 4.1-Table 2). Meander planimetry drives hyporheic flows and influences its residence times by creating differences in the elevation head of surface water around a meander bend, with spatial and temporal variations as meanders evolve (Boano et al., 2006, 2008; Revelli et al., 2008; Stonedahl et al., 2013). Naturally forced by the longitudinal head gradient, the hyporheic flows intrameander zone occur as river water infiltrates into the hyporheic zone at the upstream half of 
Hydrol. Earth Syst. Sci. Discuss., doi:10.5194/hess-2016-683, 2017

Manuscript under review for journal Hydrol. Earth Syst. Sci.

Published: 9 January 2017

(c) Author(s) 2017. CC-BY 3.0 License.

the meander and returns to the river along its downstream half (Cardenas et al., 2004; Boano et al., 2006; Kiel and Cardenas, 2014).

\subsection{Anthropogenic factors:}

The valley, its rivers and morphology, can be impacted by a broad array of human activities authoring changes in the physiographic setting (e.g., geology, morphology), on its hydrology (e.g.; river stage fluctuations) and hydraulics (e.g., altering vertical hydraulic gradients).

In the following sections we introduce potential for abrupt changes in HEF caused by i) river stage fluctuations due to hydroelectric dam and ii) changes in sediment delivery and channel complexity due to land use.

\subsubsection{Dams}

Several authors have claimed that dam-induced river stage fluctuations control hyporheic exchange by altering vertical hydraulic gradients (Winter, 1998; Hancock, 2002; Sawyer and Cardenas, 2009, Francis et al., 2010; Gerecht et al., 2011; Schmadel et al., 2016). This daily stage fluctuation from hydroelectric dams for example, has consequences on the size of the hyporheic zone and on the magnitude and frequency of HEF (Sawyer et al., 2012; Harvey and Bencala 1993; Gooseff et al. 2006; Lautz and Siegel 2006).

15 Many studies have monitored river stage fluctuations, temperature and chemistry where dams induced daily river levels fluctuations, indicating oscillation of hyporheic vertical hydraulic head and HEF with dam operations (Arntzen et al., 2006; Fritz and Arntzen, 2007). In case of dam-induced water levels changes, a temporal lag occurs between stream stage and aquifer water; HEF is transient and penetrates several meters into the riparian aquifer with residence times of hours (Sawyer and Cardenas, 2009). Schmadel et al., 2016 predicted HEF and residence times from the timing and magnitude of diel fluctuations and valley slope. Minimal exchange occurs when the magnitude of stream level fluctuations coincide with the hillslope water table, while maximum exchange occurs when stream stage is out of phase with the hillslope and therefore larger amplitude in stream and hillslope occur. Studies on thermal signals (Fanelli and Lautz, 2008; Hester et al., 2009) reported differences of HEF within the subsurface upstream and downstream of the dam to be to be attributed to the overall hydraulic behavior around the dam and to the changes in topography driven by the dam (Fanelli and Lautz, 2008). Upstream pools and downstream pools usually create with the mobilization of sediment upstream and over the dam and have the potential to drive bedform-scale exchange flow. Temperature results suggest that highest hyporheic exchange rates occur downstream of dams, while HEF is limited in upstream pools where fine sediment deposits yield low hydraulic conductivities (Fanelli and Lautz, 2008). At valley scale, the morphological changes induced by dams can lead to disruption of downstream flux of sediment with critical consequences for the alluvial structure and thus on HEF at streambed or meander scale (Creuzé des Chatelliers et al., 1994; Poole at al., 2001). 
Hydrol. Earth Syst. Sci. Discuss., doi:10.5194/hess-2016-683, 2017

Manuscript under review for journal Hydrol. Earth Syst. Sci.

Published: 9 January 2017

(c) Author(s) 2017. CC-BY 3.0 License.

\subsubsection{Land use and impacts on sediment delivery and channel complexity}

Land use in valley impacts on water levels and sediment delivery to the channel, and therefore on channel geomorphic complexity.

The simplification of landscape complexity that results from intensive land use reduces geomorphic variability and subsequently hydrostatic and hydrodynamic forces that drive hyporheic flows (Gooseff et al., 2007; Boano et al., 2014). In general urbanization and agriculture have significantly modified landscapes by altering stream flow and velocity, channel morphology, streambed sediment size and hydraulic conductivity (e.g., soil compaction) (D'angelo et al., 1993; Morrice et al., 1997; Kasahara and Wondzell, 2003; Ryan et al., 2010). This changes impact on HEF by affecting the partitioning of flow, for example, increasing surface runoff (Section 3.4) impacts HEF by competing effects from increasing fine sediment inputs (which decrease streambed hydraulic conductivity) and stream discharge (which increases the advection HEF) (Hancock, 2002; Kasahara and Hill, 2006; Crenshaw et al., 2010; Gooseff et al., 2007, Maalim et al., 2013), but the dominant process appears to be decreasing hydraulic conductivity from sedimentation within the stream channel, thus decreasing the percentage of stream water exchanged in the HZ (Cirmo et al., 1997; Doyle et al., 2005; Simon and Rinaldi, 2006; Karwan et al., 2009). Indeed, increased sediment load is not only the result of erosion, but also of low soil infiltration capacity and compaction (Birkás et al., 2009; Didoné et al., 2014). The reduce porosity of interstitial sediments, due to increased sediment loads from agricultural practices (e.g., tillage) (Patni et al., 1998; Jacobson and Gran, 1999; Elmi et al., 2002; Hancock, 2002) is usually connected to decrease of in channel storage and hyporheic exchange flows (Brunke and Gonser, 1997). Conversely, tile drainage leads to high storm flows that tend to scour and armor the stream leading to wider streambeds with coarser sediments and consequently accelerating shallow subsurface infiltration and discharge to the stream (Schottler et al., 2014).

Finally irrigation systems often include both pumping stream surface and groundwater through a system of canals; these procedures can cause water table to rise and fields water clogging (i.e. increase in groundwater inflow or decrease of stream water flow to groundwater) (Zaletaev, 1997; Winter at al., 1998; Boulton et al., 1999). Lower water tables generally reduce the vertical extent of the $\mathrm{HZ}$ by increasing water losses from the stream and reducing the hydraulic gradients that drive HEF (Hancock, 2002) (discussed in more detail in Section 4).

Not only the magnitude but also the length of the hyporheic exchange flows are affected; tracer experiments conducted on several reaches within a single land use type showed a reduction of transient storage as a function of the surrounding land use due to lower geomorphological complexity of channel scale characteristics of agricultural streams that promote the formation of reduced flow zones but less hyporheic exchange (Gooseff et al., 2007).

Urbanization alters river productivity, complexity (i.e. straightening, deepening, lining, paving), runoff, and hydrologic flowpaths (i.e. infiltration and peak flows) in a similar way to agriculture (Paul and Meyer 2001; Corbett et al. 1997, Walsh et al. 2005). However, little research has been carried out in urban rivers (Paul and Meyer 2001; Grimm et al 2005; 
Hydrol. Earth Syst. Sci. Discuss., doi:10.5194/hess-2016-683, 2017

Groffman et al., 2005). Low morphological complexity is more evident in urban areas where anthropogenic factors constrain streams substrates and planforms (Gooseff et al., 2007). Urban streams present little transient storage and more likely dominance of surficial dead zones with little or no hyporheic exchange (Gooseff et al., 2007). Urban streams are also characterized by high nutrient loads due to urban runoff and contaminated groundwater (Dahm et al., 1998; Corbett et al., 1997; Grimm et al., 2005). Additionally, urban streams generally have reduced capacity to retain N, with bioactive areas bypassed by direct inputs of storm-water drainage through piped storm-water collection systems (Grimm et al., 2005). However, N processing in urban streams still depends on in-channel geomorphic structures: Groffman et al. (2005) showed that in-channel features such as wood dams, gravel bars, pool and riffles change the nitrification and denitrification potential of urban streams. In fact, wood dams and gravel bars in suburban areas had higher denitrification than forested streams, suggesting the potential for geomorphic structures to increase nutrient uptake in urban and suburban streams (Groffman et al., 2005).

\subsection{Ecological factors}

The hyporheic zone plays an important role as a hydrological connection between riparian vegetation and the stream (Duke et al., 2007). This section covers the importance of bank vegetation for river dynamics (e.g., water table elevation, evapotranspiration) and its potential for influencing hyporheic flow, focusing on two key ecological functions: riparian vegetation and large in-channel wood.

\subsubsection{Riparian vegetation}

At valley scale, riparian vegetation is well known to shape patterns of GSE by affecting riverbank filtration and altering water-table elevations via transpiration (Chen, 2007, Jones et al., 2008). The strength of this influence is linked to the hydrogeologic scales at which the riparian and river interaction occur (Section 3.2 and Fig. 1) (Hill et al., 1998; Lowrance et al. 1997). Both vegetation composition (i.e. species) and water consumption (i.e. ET) drive nonlinear spatial variations in shallow GSE and vertical and lateral hyporheic flow patterns (Martinet et al., 2009; Wondzell et al., 2010; Larsen et al., 2014). The vegetation-groundwater dynamic is a function of inter-annual, monthly and daily variations in temperature and precipitation (Chen et al 2014; Fu and Burgher et al., 2015); Wondzell (2006) observed that during baseflow in a mountain catchment, hyporheic exchange maintains shallow aquifers throughout the valley floors of the stream, such that ET significantly reduces the flow of water which returns to the stream (Wondzell, 2006). Such ET from riparian vegetation increases hyporheic fluxes by 12 orders of magnitude at time scales of weeks to months (Larsen et al., 2014). The effect of ET on HEF is especially significant in low-energy environments, where ET drives mixing comparable to that of molecular diffusion (Larsen et al., 2014). Conversely in high-energy environments where turbulent mixing and bedform-induced pumping are very rapid (Section 4.2.2 and Fig. 1), the effect of ET will be lower. 
Hydrol. Earth Syst. Sci. Discuss., doi:10.5194/hess-2016-683, 2017

On the daily time scale, evapotranspiration changes groundwater gradients with riparian zone vegetation creating the lowest water table in the afternoon, promoting surface water infiltration and hyporheic exchange (Loheide and Lundquist, 2009; Wondzell et al., 2010). Duke et al. (2007) observed a seasonal correlation between transpiration and stream flow with hyporheic gradients: during winter, the correlation is very strong and high water tables and hillslope vegetation lead to negative hyporheic gradients and to high hydraulic head at the bank surface. Conversely in summer, the stream channel has less surface flow and less active exchange within the HZ; deep flow paths result to be very important in this period (Duke et al., 2007). At valley scale, the effect of riparian vegetation has been observed to greatly influence energy inputs to the stream by controlling nutrient retention (e.g., input and output of nutrients) from adjacent agricultural settings (Jones et al., 1995; Lowrance 1998) and controlling channel complexity (i.e. increase retention by increasing residence time and contact between stream water and hyporheic zone). This hydrological interaction has been studied in arid catchments (i.e. Sycamore Creek, a Sonoran Desert stream - Schade et al., 2002, 2005) where soils are often highly impermeable and the presence of riparian vegetation is dependent on stream flows and shallow groundwater tables (Stromberg and Patten, 1991; Stromberg et al., 1996; Schade et al., 2002; Schade et al., 2005). Arid catchments are potentially a sink for streamwater N (Peterjohn and Correll 1984; Hill et al., 1998; Hill 2000) by transformation of N and P by rooted vegetation. However, the effects of riparian vegetation on streamborne nutrients in this environment depends on the volume of water passing directly from surface to parafluvial or into riparian zone and after again to the surface of the stream (Dent et al., 2007). To the author knowledge, less is known about the effects of ET on HEF in humid streams because plants have a smaller and less obvious effect on the water balance in humid environments. The picture emerging from these studies is a complex link between the riparian vegetation, stream flow, and HEF. The direct and indirect effects of riparian vegetation on HEF at floodplain level are poorly studied relative to effects of morphology and groundwater recharge/discharge, although the studies mentioned above provide a foundation for evaluation of groundwater-dependent riparian vegetation on the HZ.

\subsubsection{Wood delivery}

Wood within valleys and stream channels drives physical complexity of the river network, leading to temporal and spatial changes of channel-floodplain connectivity, stream morphology, sediment storage and flow (Piégay and Gurnell, 1997; McHenry et al., 1998; Mutz et al., 2000; Sear et al., 2000; Jeffries et al., 2003; Phillips, 2012; Davidson and Eaton, 2013). Wood delivery to the floodplain depends on short and long terms land use and geomorphic patterns, often establishing floodplain geomorphology as the dominant control on wood storage in river systems (Gurnell et al., 2002; Benda and Bigelow, 2014). Wood that is large relative to the river channel significantly impacts flow hydraulics, sediment transfer, and habitat conditions (Osei et al., 2015). Several studies have documented the importance of woody debris in shaping the channel patterns and floodplain evolution in a variety of environments (Piégay and Marston, 1998; Collins and Montgomery, 2002; Abbe and Montgomery, 2003; Jeffries et al., 2003; Millington and Sear, 2007; Sear et al. 2010). Logjams in large alluvial 
Hydrol. Earth Syst. Sci. Discuss., doi:10.5194/hess-2016-683, 2017

rivers act as flow deflectors and block secondary channels (Abbe and Montgomery, 1996; Gurnell et al., 2001; Montgomery and Piegay, 2003), but few studies have monitored HEF responses to morphological changes induced by large wood at valley scale. Dead wood alters HEF structure and dynamics by changing valley scour, deposition, and geomorphology (Jeffries et al., 2003; Gregory et al., 2003). This suggests that the impact of wood on HEF will vary with valley topographic gradient (lowland and upland), groundwater dynamics (gaining and losing) and sediment transport (Fig. 5). Both wood and floodplain characteristics (i.e. natural fluctuation and river discharge) interact with local geomorphic effects (i.e. wood dams or jams) to drive HEF. In lowland rivers, where flow velocity is slow and gradient low, wood induces less HEF and also has less effect on spatial patterns of HEF (Krause et al., 2014). Under a temporal perspective, Wondzell (2006) observed that, although the lowland stream is sensitive to changes in wood delivery with a decrease of HEF, over longer time scale large-scale channel adjustments reverse the effect of wood removal causing higher HEF fluxes. In the long term, wood removal results in longer mean residence times, which impacts many hyporheic functions: temperature, nutrient retention, and oxygen concentrations (Sawyer and Cardenas, 2012; Stofleth et al., 2008). In upland rivers, wood typically creates steeper head gradients that drive hyporheic flow paths (Krause et al., 2014) (Fig. 5).

Beyond the influence of wood on channel morphology, log jams and natural wood jams increase variability in vertical head, and impose greater hydraulic resistance (Mutz et al., 2000, Lautz and Fanelli, 2008). Flume experiments showed that wood induces deeper HEF (Mutz et al., 2007). Wood also interacts with groundwater dynamics: debris dams positioned along gaining stream segments have an effect comparable to tight meander bends, driving water into the subsurface, where it travels along short hyporheic flow paths (Lautz et al., 2006; Boano et al., 2006). Interactions between flow and wood also produce spatial heterogeneity in deposits of sediments and organic matter (Gregory et al., 1991; Naiman et al., 2005; Latterell et al., 2006, Sear et al., 2010; Osei et al., 2015). Fines and organic rich sediments are retained, eventually driving higher spatial heterogeneity in HEF (Section 5.2 and 6). However, Kasahara and Hill (2006) observed little impact of a large woodconstructed step on oxygen concentrations within the hyporheic zone, presumably due to siltation.

\section{Reach}

In the reach scale, we outline how processes operating within the river channel drive HEF: hyporheic exchange is dependent on both characteristics of the stream flow and sediment bed (Elliott and Brooks, 1997, Packman et al., 2003; Cardenas et al 2004; O'Connor et al 2008; Harvey et al, 2013). At this scale, the increased variability in geology (e.g., sediment size), topography (e.g channel slope and width), presence and absence of wood and/or vegetation, become more influential to determine the magnitude and direction of HEF (Boano et al., 2014). 
Hydrol. Earth Syst. Sci. Discuss., doi:10.5194/hess-2016-683, 2017

Manuscript under review for journal Hydrol. Earth Syst. Sci.

Published: 9 January 2017

(c) Author(s) 2017. CC-BY 3.0 License.

\subsection{Topographical factors: channel bedforms}

Given the high spatial and temporal variability of stream channel morphology and hydraulic conductivity, actual hyporheic exchange differs from what would be expected based on average channel characteristics (Harvey and Bencala, 1993; Gooseff et al., 2003; Kasahara and Wondzell, 2003; Gooseff et al., 2007). Pressure gradients created by the bedforms drive advective pore water flow into, though, and out of the bed (Thibodeaux and Boyle, 1986; Elliott and Brooks, 1997). The interplay of constrained and unconstrained permeability zones also influences HEF (Ibrahim et al., 2010) (Section 4.3.2). Concavities and convexities modify the average gradient in-channels and may influence the convective exchange in the stream. Water upwells where permeability or depth of gravel decreases in the direction of streamflow and where the longitudinal bed profile is concave (Thibodeaux and Boyle, 1987; Harvey and Bencala, 1993; Elliott and Brooks, 1997; Tonina and Buffington, 2009). Water downwells where permeability or depth of gravel increases, in the direction of streamflow, or where the longitudinal bed profile is convex (Thibodeaux and Boyle, 1987; Harvey and Bencala, 1993; Elliott and Brooks, 1997; Tonina and Buffington, 2009).

Bedform-induced HEF processes have been broadly characterized via flume and field experiments, which have yielded relationships between hydraulic gradients with tracer movement (Elliott and Brooks, 1997; Tonina and Buffington, 2007; Cardenas and Wilson, 2007b; Janssen et al., 2012; Trauth et al., 2013; Boano et al., 2014; Fox et al., 2014; Irvine et al., 2015). Diverse bedform morphologies, for example riffle-pool and dune-ripple, induce HEF (Stonedahl et al., 2013). Bedforms develop characteristic shapes due to the interplay of stream flow and bed sediment transport (See Section 5.1 and 6). The hyporheic zone will develop around a pool-riffle sequence only where hydraulic gradients toward the stream from the sides and beneath are less or close than the longitudinal hydraulic gradient between the upstream and downstream ends of the riffle (Storey, 2003). Harvey and Bencala (1993) found upwelling zones (where hyporheic water enters the stream) and downwelling zones (where stream water enters the hyporheic zone) related to the subsurface hydraulic head patterns developed by streambed slope breaks of a pool-riffle sequence.

Riffle-scale exchange is possible only when high permeability materials surround the stream channel. Flume experiments have shown that hyporheic flow structure is controlled by spatial relationship of bedforms to high- and low-permeability regions of the streambed (Packman et al., 2004). Modelling studies have showed that flow paths and exchange rate vary in the alluvium around riffles across seasons and with the extent of groundwater discharge (Storey, 2003; Stonedahl et al., 2012). In a pool-step-riffle system multiple nested scales of downwelling and upwelling are distributed over a wide range of hyporheic wavelengths, demonstrating the influence of local-scale variation in the size of channel morphologic features in determining the longitudinal pattern of upwelling and downwelling within a stream reach (Gooseff et al., 2006). Gravel bars are also functionally equivalent to riffle-pool systems; the hydrologic retention in gravel bars is strongly influenced by bar structure and stream water levels (Boulton et al., 1998; Trauth et al., 2015). Unlike fully submerged features, recent findings by Trauth et al. (2015) suggest that HEF in partially submerged gravel bars decreases with increasing stream discharge as the hydraulic head gradients across the bedform decrease, leading to long residence times under low flow conditions. 
Hydrol. Earth Syst. Sci. Discuss., doi:10.5194/hess-2016-683, 2017

In lowland rivers, the lower slope, finer sediments and more constant flows favour the development of dune-ripple sequences (Elliott and Brooks, 1997; Marion et al., 2002) characterized by high relative submergence and smooth water surface profiles (Packman et al., 2004). Under these conditions, the spatial variation of water surface topography is minimized and HEF is induced primarily by dynamic pressure variations. Because they occur in lowland rivers, dune-ripple streams typically exhibit less spatial and temporal variability in water surface elevation than riffle-pool streams (Tonina and Buffington, 2011). Finally, modelling simulations suggest that dunes contribute more than meanders and bars to hyporheic exchange flows in lowland rivers (Stonedahl et al., 2013; Gomez-Velez et al., 2015).

The above studies suggest that in-channel bedforms often control HEF, although these local exchange flows are still strongly modulated by stream and groundwater dynamics. Therefore, comprehensive understanding of a range of hydraulic conditions (e.g., stream discharge, stream stage, neutral, losing, and gaining reaches) is generally needed to accurately assess the efficiency of in-stream bedforms in driving HEF.

\subsection{Hydrogeological factors: near-stream HEF}

Sedimentological properties strongly control hyporheic functions at reach scale, particularly where fine sediments accumulate and clog pores in coarser bed material (Gilbert et al., 1990; Brunke and Gonser, 1997; Bardini et al., 2012; Hartwig and Borchardt, 2015; Kasahara et al., 2013). Water flowing through the river bed is affected by sediment grain size, sediment heterogeneity, and depth, therefore promoting spatially diverse hyporheic exchange (Packman et al., 2004). Given the direct coupling of stream and pore water flow, exchange is generally greatly enhanced in coarser sediments (Packman et al., 2004). High velocity gradients and turbulence generated at the surface of coarse sediment beds can also increase diffusion processes which can produce considerable exchange even when the bed surface is flat and no flows are induced by bed topography (Packman et al., 2004, Marion et al., 2008). The presence of high hydraulic conductivity layers in the streambed can increase dispersive mixing between hyporheic water and groundwater (Hester et al., 2013) and create preferential HEF, either short or long, by controlling the ability of the sediment to support advective pumping (Salehin et al., 2004; Cardenas, 2008a, 2009b; Pryshlak et al., 2015). Dye injections have shown that hyporheic flow patterns are controlled by the spatial relationship of high and low permeability regions of the streambed, resulting into faster near-surface transport and shallower penetration and a shorter mean residence time (Salehin et al., 2004). Further, longer hyporheic flow paths are generated in streams having greater connectivity of sediment strata (Pryshlak et al., 2015). HEF are also influenced by natural changes in permeability across scales (i.e. depositional features in fluvial deposits-Section 3.3 and 4.3) suggesting that the connectivity between stream morphology and permeability layers has a fundamental role in HEF and hyporheic residence time (Section 6). To date, few studies have addressed the variability of HEF driven by sediment heterogeneity at larger scale, although recent works have showed strong impact of sand and gravel deposits on HEF at the reach scale (Zhou et al., 2014) and identified sediment heterogeneity as one of the main drivers of laterals connectivity as well (Pryshlak et al., 2015). 
Hydrol. Earth Syst. Sci. Discuss., doi:10.5194/hess-2016-683, 2017

Manuscript under review for journal Hydrol. Earth Syst. Sci.

Published: 9 January 2017

(c) Author(s) 2017. CC-BY 3.0 License.

(c) (i)
Hydrology and

Earth System

Sciences

Discussions

\subsection{Ecological factors: in-channel vegetation}

In-channel vegetation directly influences channel-scale flow resistance and thus controls HEF directly via local advective subsurface exchange and indirectly via streambed permeability factors and in-stream storage (Packman et al., 2000; Packman et al., 2003; Jones et al., 2008). A variety of herbs, shrubs and trees grow in stream channels, increasing bed roughness and driving specific relationships with hydraulic conditions and the development of preferential flow pathways (Corenblit et al., 2007). Vegetation also alters stage-discharge relationships that affect hyporheic flow (Champion and Tanner, 2000; Harvey et al., 2003; Heppell et al 2009). Jones et al. (2008) demonstrated that in-channel vegetation restructures hyporheic flow patterns by creating temporally dynamic deviations of hydraulic gradients. Certainly, in-channel vegetation increases the friction factor (Kutija and Hong, 1996; Harvey et al. 2003), but Worman et al 2004 and Kjellin et al. 2007 also observe that the spatial distribution of vegetation often leads to a channeling flow patterns and the creation of low flow areas that increase water residence time (Section 4.5.1) (Salehin et al., 2003; Ensign et al., 2005). This aspect has been observed especially in streams with extensive vegetation where flow can decrease to zero within the stands, the volumetric capacity of the storage changes as HEF do (Salehin et al., 2003; Ensign et al., 2005). On the other hand, the reduction of flow velocity within plant stands leads to increased sediment deposition and the development of plant-mediated sediments that are typically finer-grained than the bed material with more organic material and lower permeabilities (Corenblit et al., 2007), which would reduce HEF. Overall, both field and laboratory studies have suggested that vegetation have a role in shaping transient storage in streams channels, even though there are still difficulties in understanding the single feedback of mixing due to vegetation and to induced HEF at this spatial scale. 
Hydrol. Earth Syst. Sci. Discuss., doi:10.5194/hess-2016-683, 2017

\section{Synthesis}

Following on from the presentation of factors influencing HEF at the catchment, valley and reach scales, in this section we illustrate how interactions between these factors are ultimately responsible for rates and patterns of HEF in river systems. The overlay of factors from different scales creates spatial heterogeneity and temporal variability in HEF. Using key examples from the literature, we link the hydrological, geological, topographical, ecological and anthropogenic factors at different spatial scales to support predictions of hydrologic forcing and geomorphology. To facilitate this synthesis, we separate out HEF that is primarily lateral, i.e. driven by interactions with the floodplain and aquifer, and vertical, i.e. driven by processes internal to the river channel. This distinction allows us to more clearly appreciate the multidimensionality of HEF patterns in different types of rivers.

\subsection{Lateral hyporheic exchange flow: valley types and confinement}

While two recent studies have observed vertical and lateral exchange throughout the Mississippi River watershed (Kiel et al., 2014; Gomez et al., 2014), lateral exchange has been explored mostly by modelling studies, and much less field data are available on lateral hyporheic exchange than on vertical exchange. Most studies have focused on a single factor or a subset of factors, despite the fact that lateral hyporheic flows are known to be modulated by processes at at least two scales: channel planform (valley scale) and bedform morphology (channel scale) (Stonedahl et al., 2013).

As lateral hyporheic exchange is primarily the connection between the river channel and its banks, valley confinement and type have a secondary control on HEF through their impacts on the presence of groundwater and its connection to the river, as well as though interactions with channel patterns and associated floodplain structures. Overall, in a sinuous or meandering river, the prevailing valley gradient generally produces upwelling fluxes on the up-valley side of the stream channel and downwelling fluxes on the down-valley side of the stream channel. In this regards, sinuosity is often used as a measure of valley complexity and has been seen to be directly correlated with lateral hyporheic exchange in meander bends, and in parafluvial zone (area of the bankfull scoured by flooding) close to the rive channel (Holmes et al., 1996; Wroblicky et al., 1998; Boano et al., 2006; Cardenas, 2008a). Meanders drive hyporheic flows and influence hyporheic residence times by creating differences in the elevation head of surface water around a meander bend, with spatial and temporal variations as meanders evolve (Boano et al., 2006, 2008; Revelli et al., 2008; Stonedahl et al., 2013). Forced by the longitudinal head gradient along the river channel, river water infiltrates into the hyporheic zone at the upstream half of each meander and returns to the river along the downstream half (Cardenas et al., 2004; Boano et al., 2006; Kiel and Cardenas, 2014).

This general pattern becomes more complex with the inclusion of floodplain sediment and channel geomorphic features. Lateral hyporheic residence time is short in areas with coarse floodplain sediments and high sediment hydraulic conductivity (Pinay et al., 2009) and increases in meanders with fine-textured sediments (Boano et al., 2006; Peterson et al., 2006). Mason et al. (2012) observed variations in the hydrological transport and of in-channel water velocity after large scale channel 
Hydrol. Earth Syst. Sci. Discuss., doi:10.5194/hess-2016-683, 2017

realignment along the Silver Bow Creek in the south-western Montana. By increasing channel sinuosity and decreasing channel slopes, the restoration increased water residence time at valley scale and decreased complexity at bedforms scale with a shift from large embedded cobbles to sandy gravel channels (Mason et al., 2012). The use of regular channel spacing and smaller roughness elements during restoration leaded to uniform water velocity paths and slower advective velocities (Mason et al., 2012). In this particular case at Silver Bow Creek in Montana, the reduced reach-averaged channel slope and the presence of frequent pools yielded to a significant (42\%) decrease of down-valley advection rates and to a reduced average channel residence time. This study emphasizes that not all channel bedforms always contribute to HE when the hydraulic properties of the streambed, discharge rate, water level and their variability change too (Stonedahl et al., 2013). Both Mason et al. (2012) and Hester and Cranmer (2014) emphasize that river sinuosity and lateral hyporehic exchange are controlled by multi-scale alteration of topography (channel geometry, stream depth and height of bedform units ) which in the case of Mason et al. (2012) study, yielded to a decrease in the variability of bedforms in the restored channel in turn limiting HEF along short paths.

Also the extent of valley confinement (Section 4) determines the capacity of the river to adjust in planform, and consequentially controls lateral HEF (Section 4 and Table 2). In case of bedrock confinement for example, the presence of bedrock spurs will strongly limit capacity for lateral hyporheic exchange because the overall river channel is constrained by the bedrock (Tonina and Buffington, 2009). In this setting, spring channels and bedrock fractures contribute substantially to vertical hyporheic exchange. Jones et al (2008) observed shifting patterns of vertical hyporheic flow directions due to the presence of small off-channel features which restructured both HEF and water-table elevations (See Supplementary Material). In partially confined valleys, the occurrence of irregular meanders and bends creates pools and pockets that increase lateral hyporheic exchange. In multi-thread channels, model simulations have identified the importance of hyporheic flow paths beyond the active channels toward secondary channels and across the floodplain (Kasahara et al 2003, See Supplementary Material). Along laterally unconfined valleys, meander creation, extension and cutoff allow significant river adjustment and river-floodplain interactions, causing both in-stream and off-channel geomorphic features to drive lateral hyporheic exchange (Boano et al., 2006). In this case, the presence or absence of riparian vegetation and the composition of confining materials strongly influence lateral HEF over a wide range of scales (Wagner and Bretschko, 2000).

Finally, valley topography can affect both lateral and vertical hyporheic flows and therefore be used as qualitative and quantitative predictor of hyporheic potential (Anderson et al., 2005; Poole at al., 2006). Additionally, topographical confinement can provide important clues about disconnection within catchments and give new insights for management solutions. 
Hydrol. Earth Syst. Sci. Discuss., doi:10.5194/hess-2016-683, 2017

\subsection{Vertical hyporheic exchange: bedform-induced flow}

The effect of in-channel geomorphic structures, embedded within the spatial context of channel-scale planform and valley morphology, in driving hyporheic exchange has started to be acknowledged. Riffles, bars, dune and other bedforms each influence vertical hyporheic exchanges, but these processes have primarily been investigated at single spatial scales (Boano et al., 2014). Hyporheic flows can be induced by bedforms at very fine scales and follow very shallow flow paths (i.e. centimeterscale under small dunes and ripples) (Elliott and Brooks, 1997; Stonedahl et al., 2013) and scale up to flow paths up to hundreds of meters in length and tens of meters in depth under large rivers (i.e. large dunes and bars) (Wörman et al., 2007; Stonedahl et al., 2013). Through the interplay of stream flow, bed sediment transport, and channel friction, submerged topography influences water surface topography, flow depth, and pressure gradients which in turn affects HEF (Fig. 9). Channel bedform sequences, such as riffle-pool and dune-ripple, affect HEF due to hydrostatic forces at valley scale (i.e. groundwater-surface water interactions, river discharge, topography) and hydrodynamic forces at sub-reach scales (i.e. streambed roughness, bedform submergence) (Tonina, 2005; Stonedahl et al., 2013). In this section we will discuss different types of bedforms (step-pool, riffle-pool, dune-ripple), alone and in sequence, and the hydrological (e.g., flow regime) factors affecting the magnitude and the depth of HEF over bedforms under diverse valley settings. Step-pool morphology behaves differently than pool-riffle and dune-like bedform (Storey et al., 2003; Tonina and Buffington, 2007; Marzadri et al., 2010; Hassan et al., 2015) because the depth of hyporheic exchange increases with channel slope and deeper vertical exchanges develops at high slope.

In gravel bed riffle-pool sequences, significant elevation differences across the channel, high permeability of sediment and low submergence time generate substantial large-scale hyporheic flow (Wondzell and Swanson, 1996). Dune-ripple sequences (Elliott and Brooks, 1997; Marion et al., 2002) are characterized by high relative submergence time and smooth water surface profile (Packman et al., 2004) implying that the spatial variation of water surface topography is minimized and the pressure profile strongly depends on dynamic pressures. Dune-ripple complexes are less influenced by spatial and temporal changes in water surface elevation than riffle-pool sequences (Tonina and Buffington, 2011); modelling simulations show that dunes contribute more than meanders and bars to hyporheic exchange flows (Stonedahl et al., 2013). In fact, the hyporheic flows induced by topographic features, have been simulated for sand bed streams showing that the volume of water exchanged and the hyporheic residence time across bedforms is not linearly additive (Stonedahl et al., 2013). Instead, hyporheic exchange is maximized when one topographic feature dominates (Stonedahl et al., 2013). These findings stress the need to consider hyporheic exchange in a holistic manner across all relevant scales of river morphology, which will enable co-variations between flow, slope, valley confinement, sediment size, and river planform and bedform morphology to be identified. When bedforms are analyzed with respect to channel gradient, it can be seen that gentle slopes of lowland rivers generate slower currents with deeper flows, lower relative roughness, and less valley confinement, resulting in less bedform-induced exchange (Tonina and Buffington, 2007) (Fig. 6). 
Hydrol. Earth Syst. Sci. Discuss., doi:10.5194/hess-2016-683, 2017

Channel bedforms can significantly control channel hydraulics and HE under conditions of low flow and partial submersion (ref?). This is consistent with flume experiments suggesting that increasing discharge reduces the magnitude and depth of hyporheic exchange in both step-pool and riffle-pool systems (Tonina and Buffington, 2007, 2011; Hassan et al., 2015). Moderate discharges produce deeper hyporheic flows than high or low ones, with significant volumes of stream water extending

deep into the channel alluvium (Hassan et al., 2015). In these systems, HEF decreases with increasing river discharge as the bed topography becomes increasingly submerged, which decreases spatial variations in the water surface (Tonina, 2005). Conversely, discharge has minor effects on hyporheic depth when mean groundwater velocity is high, as groundwater discharge reduces hyporheic flows and residence times (Tonina, 2005; Fox et al., 2015). In lowland catchments with relatively low-permeability sediments and deep alluvium, the effect of low rates of groundwater discharge is negligible. Hyporheic flows are deeper and follow the longitudinal axis of the river with local topography that directs exchange flows to pool-riffles units. As groundwater discharge increases, hyporheic flows become simpler and more two-dimensional (downstream and vertical). Hence, in lowland settings, heterogeneities can enhance or limit the hyporheic residence time depending on the relative configuration of subsurface stratigraphy and channel bedforms (Cardenas et al., 2004). Only limited empirical evidence has been collected within natural channels to link local-scale variability with the larger context of valley settings and ground-surface water interactions (Gariglio et al., 2013).

Most of the current knowledge of hyporheic fluxes and their spatio-temporal variability in submerged bedforms has been obtained from simulations and laboratory experiments, owing to the difficulties in making high-resolution subsurface measurements within stream channels. However, the complexity of ground-surface water interactions and stream flow regimes increase the complexity of cross-scale hyporheic exchanges. In this regard, a detailed case study on a upland, gravel-bed river with a riffle-pool bedform sequence showed that, although the expected pattern of downwelling and upwelling conditions were generally observed along the bedform sequence, seasonal variations in hyporheic fluxes occurred because of asynchronous local ground water recharge relative to flow regime (Gariglio et al., 2013). At riffle-pool scale this is consistent with previous studies reporting seasonal variations in hyporheic temperature dynamics, with stream topography, sediment stratification, and groundwater interaction all affecting local upwelling and downwelling in riffle-pool systems (Hannah et al., 2009; Krause et al., 2011b, 2013).

\subsection{Case study: the River Tern}

To illustrate the challenges in resolving hyporheic exchange across scales, we use the River Tern (UK) as a case of study. Through a presentation of results from previous research, we demonstrate how the patterns of vertical hyporheic exchange observed at reach scale are determined by spatial and temporal variations in floodplain characteristics and water levels Then, we build upon this knowledge base, drawing inference form the literature in Sections 3-5, to discuss 
Hydrol. Earth Syst. Sci. Discuss., doi:10.5194/hess-2016-683, 2017

Manuscript under review for journal Hydrol. Earth Syst. Sci.

Published: 9 January 2017

(c) Author(s) 2017. CC-BY 3.0 License.

the possibility of lateral hyporheic exchange occurring in a valley section given the geomorphological and sedimentological properties of the site.

The River Tern is a major tributary of the River Severn in the North Shropshire plain with a total catchment area of $852 \mathrm{~km}^{2}$. The catchment is low-lying, with average elevations between 50 and $120 \mathrm{~m}$. The area is predominantly agricultural, with croplands and pastures accounting for the majority of the land area (Fuller et al., 2002). The River Tern and its tributaries are underlain by Permo-Triassic sedimentary rocks (sandstone and conglomerate interbedded), which dominate river-aquifer interactions at regional scale (Allen et al., 1997). This permeable geology supports unconfined highly, moderately-productive aquifers characterized by intergranular flows. Rivers flow is dominated by groundwater discharge in summer but autumn/winter periods are more influenced by episodic precipitation (Clay et al., 2004). However, most of the superficial geology of the catchment is from the Pleistocene age, ranging from sand and gravel to diamicton, peat and clay. The thickness varies spatially across the catchment, with thicker areas in the western part of the catchment comprising up to $30 \mathrm{~m}$ of till (Streetly and Shepley, 2005). Clay and peat lenses have been identified from borehole monitoring sampling in the catchment (Adams et al., 2003). Consequently, hydrographs for the River Tern typically show flashy responses after prolonged rainfall.

Vertical HEF has been extensively studied in the River Tern, with results indicating that spatial variations in superficial geology of the floodplain and temporal variations in groundwater levels provide local controls on river aquifer interactions, and dictate the rates and patterns of HEF (Krause et al., 2011b; Angermann et al., 2012a; Krause et al., 2013). Pumping tests carried out at abstraction wells in the catchment reveal strong correlations between rainfall and groundwater levels, indicating that the river acted as a recharge boundary and that hydraulic continuity of bedrock with the River Tern was apparently greater at high flows than at low flows (Streetly and Shepley, 2005). At more local scales, Hannah et al. (2009) and Angermann et al. (2012a) found that spatial heterogeneity in HEF is controlled by both topography and streambed strata. Substantially, heat tracer studies identified inhibition of hyporheic flow in peat and clay lenses within the surficial geology below the stream (Angermann et al., 2012a). Because of this structure, hyporheic flow paths in riffles did not coincide with the patterns expected from topography-induced head distributions, and instead seem to be driven by locations of confining peat and clay strata (Angermann et al., 2012a). Temperature data indicated that advected surface water or groundwater controlled heat transport within the hyporheic zone (Hannah et al., 2009). Hannah et al. (2009) and Anibas et al. (2012) showed that the local hydrogeological and geomorphological context explains the observed seasonal thermal differences between riffles: increased downwelling at riffle tails during winter results from greater groundwater influence and high water stage (Fig. 6). These results highlight the need to integrate interpretations of observed rates and patterns of hyporheic exchange with hydrogeological and geomorphological context (Hannah et al., 2009). 
Hydrol. Earth Syst. Sci. Discuss., doi:10.5194/hess-2016-683, 2017

From previous research, we now know that the mosaics of hyporheic exchange in the River Tern are induced by spatial variations in streambed topography and sediment permeability and temporal variations in groundwater recharge. However to extend these findings beyond the short study reach to the rest of the River Tern, we must use evidence from coarse spatial scales to inform the likelihood of hyporheic exchange. As a starting point, valley type can be used to predict the development and extent of lateral hyporheic exchange. We illustrate the generic nature of valley confinement for the River Tern considering the headwater valley of the Tern at Norton-in-Hales and including the $150 \mathrm{~m}$ reach considered in previous studies (Hannah et al., 2009). This valley section has an elevation ranging from 91 to $114 \mathrm{~m}$, low gradient between 0 and $0.2 \%$ and it is laterally unconfined. Channel planform is mostly meandering, and is not constrained by bedrock. Throughout the length, the river is fringed by wet woodland, predominantly Alnus glutinosa. The bedrock is mainly sandstone and mudstone, whereas the superficial geology is sand and gravel with some silt, clay and diamicton. We divided the valley into reach sections of $900 \mathrm{~m}$ and analyzed the confinement according to the method of Fryirs et al (2016). Some reaches are laterally constrained by anthropogenic structures (roads, houses) in one or both sides (Table 3, Fig. 9). The anthropogenic confinement is most prominent in proximity to the town, where the active floodplain is artificially disconnected (e.g., roads, bridge). We expect lateral hyporheic flows to occur predominately in unconfined areas, especially where the channel planform can adjust to its sinuous-meandering shape (i.e. reach 1, 4,5,6,7,8,9,10).

At the same time, we expect it to vary across reaches when arenaceous and rudaceous lithologies dominate on argillic and peat sediments (i.e. 2,4,5,6,8,9). Finally, we expect difference along the general gradient of the network, where the conjunction of increase of riverbed slope, the presence of meander bends and of bedform will likely increase hydraulic head gradients and favor hyporheic flowpaths (i.e. 4,5,7,8). However, detailed observations in the field are needed to validate these hypotheses.

Through this case study we have endeavored to demonstrate how factors operating over multiple spatial and temporal scales can affect HEF. The explicit multiscale approach we outlined can be used as a framework to build scale relationships and estimate HEF (qualitatively at first, but hopefully quantitatively one day) from basic patterns of channel morphology, valley confinement, hydrogeological properties, etc.

\section{Outlook}

The hyporheic zone is a central interface within the catchment water regime, and as such hyporheic flows result from nested processes occurring at many different scales. Accounting for all the factors that regulate hyporheic exchange is challenging, and available methods for assessing multiscale interactions are limited. However, in this review we demonstrate the importance of considering factors at multiple scales. We show using examples from the literature that large-scale catchment patterns have profound influences on rates and patterns of small-scale hyporheic flows, and that an understanding of river topography, geomorphology, and hydraulics provides critical insights into mechanisms of vertical and lateral hyporheic exchange. However more field evidence of these processes is needed to support these findings. Likewise, better integration is 
Hydrol. Earth Syst. Sci. Discuss., doi:10.5194/hess-2016-683, 2017

Manuscript under review for journal Hydrol. Earth Syst. Sci.

Published: 9 January 2017

(c) Author(s) 2017. CC-BY 3.0 License.

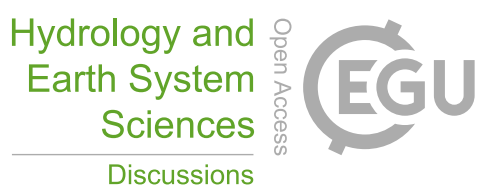

(c) (i)

needed between laboratory flume experiments, model-based simulations and multi-scale field observations. Whole-catchment approaches are needed to quantify the extent to which stream-catchment connections occur over all relevant scales. Accordingly, future work should evaluate the characteristics of hyporheic flows in conjunction with and embedded within catchment and valley characteristics, and encourage development of multi-scale approaches to better inform factors that control hyporheic exchange flows at whole-catchment scales.

Author contribution: C. Magliozzi developed and prepared the manuscript with contribution from all co-authors.

Acknowledgements: This work was supported by the Marie Sklodowska-Curie Action, Horizon2020 within the project

HypoTRAIN. Grant agreement no: 641939. A. I. Packman was also supported by U.S. NSF grant EAR-1344280. 
Hydrol. Earth Syst. Sci. Discuss., doi:10.5194/hess-2016-683, 2017

Manuscript under review for journal Hydrol. Earth Syst. Sci.

Published: 9 January 2017

(c) Author(s) 2017. CC-BY 3.0 License.

(c) (1)

Table 1. List of the factors in each spatial scale examined in this review.

\begin{tabular}{lll}
\hline Spatial Scale & Factors & Dependent-processes \\
\hline Catchment & $\begin{array}{l}\text { Hydrological } \\
\text { Topographical }\end{array}$ & $\begin{array}{l}\text { Water-delivery, precipitation } \\
\text { Local min and max. Groundwater } \\
\text { discharge and recharge. }\end{array}$ \\
& Anthropogenic & $\begin{array}{l}\text { Aquifer geometry and its geological } \\
\text { heterogeneity }\end{array}$ \\
Valley & Hydrological & $\begin{array}{l}\text { Land management and surface } \\
\text { hydrology }\end{array}$ \\
& Topographical & $\begin{array}{l}\text { Groundwater dynamics and seasonal } \\
\text { and event-based changes of flow } \\
\text { regime }\end{array}$ \\
& Geological & Valley gradient and type \\
Anthropogenic & Superficial geology in floodplains type \\
& Ecological & $\begin{array}{l}\text { Dams and land use on sediment } \\
\text { delivery and channel complexity }\end{array}$ \\
Topography & Riparian vegetation and wood delivery \\
Reach & Geology & Channel bedforms \\
Ecological & Bed sediment \\
& & In-channel vegetation
\end{tabular}


Hydrol. Earth Syst. Sci. Discuss., doi:10.5194/hess-2016-683, 2017

Manuscript under review for journal Hydrol. Earth Syst. Sci.

Published: 9 January 2017

(c) Author(s) 2017. CC-BY 3.0 License.

Table 2. Expected hyporheic exchange flows in different channel types. Geomorphic unit refers exclusively to in-channel features. Sources Buffington and Tonina (2009), Wondzell and Gooseff (2013), Gurnell et al. (2016), Nanson and Croke (1992).

\begin{tabular}{|c|c|c|c|c|c|c|}
\hline $\begin{array}{l}\text { Floodplain } \\
\text { type }\end{array}$ & $\begin{array}{l}\text { Characteristics } \\
\text { floodplain }\end{array}$ & $\begin{array}{l}\text { Floodplain } \\
\text { geomorphic } \\
\text { units }\end{array}$ & $\begin{array}{l}\text { Expected HEF } \\
\text { floodplain scale }\end{array}$ & $\begin{array}{l}\text { Channel } \\
\text { planform } \\
\text { type }\end{array}$ & $\begin{array}{l}\text { Channel } \\
\text { geomorphic } \\
\text { units }\end{array}$ & $\begin{array}{l}\text { Expected HEF } \\
\text { channel }\end{array}$ \\
\hline \multirow[t]{2}{*}{$\begin{array}{l}\text { Confined } \\
\text { Steep/narrow } \\
\text { valley }\end{array}$} & \multirow[t]{2}{*}{$\begin{array}{l}\text { High energy } \\
\text { river. } \\
\text { Coarse sediment } \\
\text { from poorly } \\
\text { sorted } \\
\text { boulders and } \\
\text { gravels with } \\
\text { sands and soils } \\
\text { to basal gravels } \\
\text { with sand and } \\
\text { silt }\end{array}$} & \multirow[t]{2}{*}{$\begin{array}{l}\text { Large boulder } \\
\text { levee, } \\
\text { deep black } \\
\text { channels, } \\
\text { scour holes. }\end{array}$} & \multirow[t]{2}{*}{$\begin{array}{l}\text { Confined HEF } \\
\text { which is } \\
\text { driven by in } \\
\text { channel } \\
\text { geomorphic } \\
\text { units. } \\
\text { Short residence } \\
\text { times. }\end{array}$} & $\begin{array}{l}\text { Colluvial: } \\
\text { Single-threat } \\
\text { or straight } \\
\text { sinuous. }\end{array}$ & $\begin{array}{l}\text { Rock-steps } \\
\text { cascades } \\
\text { Rapids }\end{array}$ & $\begin{array}{l}\text { Colluvial channels are } \\
\text { usually strongly } \\
\text { confined and stable. } \\
\text { Very coarse and } \\
\text { supply-sediment } \\
\text { limited. Cascade and } \\
\text { rock steps would likely } \\
\text { allow head variations } \\
\text { and near-bed turbulence } \\
\text { which enhance HEF }\end{array}$ \\
\hline & & & & $\begin{array}{l}\text { Alluvial: } \\
\text { Single -threat } \\
\text { or straight } \\
\text { sinuous }\end{array}$ & $\begin{array}{l}\text { Small pools } \\
\text { Step-pools } \\
\text { Bars }\end{array}$ & $\begin{array}{l}\text { Alluvial channels are } \\
\text { relatively stable for } \\
\text { long (very coarse to } \\
\text { coarse material). } \\
\text { Broken -fast flowing } \\
\text { turbulent flow. Where } \\
\text { step-pool units occur } \\
\text { the HEF is enhanced. }\end{array}$ \\
\hline $\begin{array}{l}\text { Braided } \\
\text { confined/ } \\
\text { partly } \\
\text { confined/ } \\
\text { unconfined }\end{array}$ & $\begin{array}{l}\text { Medium energy. } \\
\text { Abundant } \\
\text { sediment load } \\
\text { from gravel } \\
\text { to sand and } \\
\text { silt }\end{array}$ & $\begin{array}{l}\text { Abandoned } \\
\text { channels, } \\
\text { bars, } \\
\text { islands. }\end{array}$ & $\begin{array}{l}\text { Developing of } \\
\text { lateral HEF } \\
\text { enhanced by } \\
\text { alluvium } \\
\text { and head } \\
\text { variations } \\
\text { (hydraulic } \\
\text { conductivity). } \\
\text { High residence } \\
\text { time. }\end{array}$ & $\begin{array}{l}\text { Alluvial } \\
\text { channels } \\
\text { Multi-thread }\end{array}$ & $\begin{array}{l}\text { Pools } \\
\text { Riffles } \\
\text { riffle-pools } \\
\text { Laterals bars } \\
\text { Mid-channel } \\
\text { bars } \\
\text { Islands }\end{array}$ & $\begin{array}{l}\text { Highly instable } \\
\text { vertically and laterally. } \\
\text { Sediment supply high. } \\
\text { Expected head } \\
\text { variations, alluvial } \\
\text { volume variations and } \\
\text { hydraulic conductivity } \\
\text { variations that likely } \\
\text { enhance HEF }\end{array}$ \\
\hline $\begin{array}{l}\text { Sinuous } \\
\text { meandering }\end{array}$ & $\begin{array}{l}\text { Medium energy } \\
\text { Mostly sands } \\
\text { with silts and } \\
\text { some gravels }\end{array}$ & $\begin{array}{l}\text { Smooth to } \\
\text { undulating } \\
\text { floodplain surface } \\
\text { often with areas } \\
\text { of vertically } \\
\text { accreted fine } \\
\text { sediments, } \\
\text { backswamps, } \\
\text { ponds }\end{array}$ & $\begin{array}{l}\text { Developing of } \\
\text { lateral HEF } \\
\text { enhanced by } \\
\text { alluvium and } \\
\text { head variations } \\
\text { (hydraulic } \\
\text { conductivity) } \\
\text { or limited by } \\
\text { fine deposited } \\
\text { areas. High } \\
\text { residence time. }\end{array}$ & $\begin{array}{l}\text { Single thread- } \\
\text { sinuous } \\
\text { or meandering }\end{array}$ & $\begin{array}{l}\text { Pools } \\
\text { Riffles } \\
\text { Point bars } \\
\text { Bars } \\
\text { Dunes }\end{array}$ & $\begin{array}{l}\text { Relatively unstable and } \\
\text { subjected to progressive } \\
\text { migration. The } \\
\text { instability reflects the } \\
\text { geomorphologic units } \\
\text { that likely promote } \\
\text { the HEF }\end{array}$ \\
\hline Anabranching & $\begin{array}{l}\text { Low energy } \\
\text { Fine sediments } \\
\text { from silts and } \\
\text { clays } \\
\text { to sands }\end{array}$ & $\begin{array}{l}\text { Flat floodplains, } \\
\text { extensive islands, } \\
\text { peat and lakes } \\
\text { swamps, } \\
\text { splayes, } \\
\text { possible side } \\
\text { levee }\end{array}$ & $\begin{array}{l}\text { Vertical } \\
\text { hyporheic } \\
\text { exchange } \\
\text { enhanced or } \\
\text { limited } \\
\text { by alluvium and } \\
\text { head variations. }\end{array}$ & $\begin{array}{l}\text { Multi-thread } \\
\text { anabranching }\end{array}$ & $\begin{array}{l}\text { Islands, } \\
\text { ripples and } \\
\text { dunes, } \\
\text { abandoned } \\
\text { channels }\end{array}$ & $\begin{array}{l}\text { Predominantly stable. } \\
\text { Channel variation in } \\
\text { sediment alluvium } \\
\text { would } \\
\text { likely drive some } \\
\text { vertical HEF. }\end{array}$ \\
\hline
\end{tabular}


Hydrol. Earth Syst. Sci. Discuss., doi:10.5194/hess-2016-683, 2017

Manuscript under review for journal Hydrol. Earth Syst. Sci.

Published: 9 January 2017

(c) Author(s) 2017. CC-BY 3.0 License.

Table 3. Valley is divided into sections of $850 \mathrm{~m}$ for a total of 10 reach sections. Surface geology and valley type are evaluated with respect to the extent of lateral hyporheic exchange. The sections are enumerated and described from upstream to downstream. Information of geology extracted from the British Geological Survey website.

\begin{tabular}{|c|c|c|c|c|c|}
\hline \multirow{2}{*}{$\begin{array}{c}\text { Reach } \\
\text { Section }\end{array}$} & \multicolumn{2}{|c|}{ Geology } & \multirow[t]{2}{*}{ Description } & \multirow[t]{2}{*}{ Gradient Channel (\%) } & \multirow[t]{2}{*}{ Sinuosity } \\
\hline & Underlying geology & In-channel sediment & & & \\
\hline 1 & $\begin{array}{l}\text { Sandstone- } \\
\text { conglomerate bedrock } \\
\text { of Triassic period. } \\
\text { Superficial geology, } \\
\text { sedimentary substrate } \\
\text { of quaternary period. } \\
\text { Alluvial, fluvial and } \\
\text { glacigenic sediments }\end{array}$ & $\begin{array}{l}\text { Min grain is clay. } \\
\text { Max grain is } \\
\text { gravel.Mixed argillic } \\
\text { and arenaceous grains. }\end{array}$ & $\begin{array}{l}\text { Unconfined valley on } \\
\text { both banks. The river } \\
\text { is meandering and the } \\
\text { riparian vegetation is } \\
\text { abundant }\end{array}$ & 0.001 & 1.089 \\
\hline 2 & $\begin{array}{l}\text { Mudstone and } \\
\text { sandstone bedrock of } \\
\text { Triassic period. } \\
\text { Superficial geology, } \\
\text { sedimentary substrate } \\
\text { of quaternary period. } \\
\text { Alluvial and } \\
\text { glaciofluvial } \\
\text { sediments. }\end{array}$ & $\begin{array}{l}\text { Predominant min } \\
\text { grain is sand and max } \\
\text { grain is gravel. } \\
\text { Dominant grain is } \\
\text { sand. Arenaceous - } \\
\text { rudaceous grains. }\end{array}$ & $\begin{array}{l}\text { Partially confined } \\
\text { valley due to } \\
\text { industrial plants and } \\
\text { homes on the right } \\
\text { bank of the river. The } \\
\text { river is sinuous with } \\
\text { the presence of a big } \\
\text { meander and abundant } \\
\text { riparian vegetation }\end{array}$ & 0 & 0.487 \\
\hline 3 & $\begin{array}{l}\text { Bedrock: mudstone } \\
\text { and sandstone } \\
\text { interspersed. } \\
\text { Sedimentary geology } \\
\text { of Triassic period. } \\
\text { Dominance of fluvial } \\
\text { sediments. }\end{array}$ & $\begin{array}{l}\text { Min grain mud and } \\
\text { clay and max grain is } \\
\text { gravel. Dominant } \\
\text { grains sand and mud. } \\
\text { Argillic -rudaceous } \\
\text { grains. }\end{array}$ & $\begin{array}{l}\text { Partially confined } \\
\text { valley due to homes } \\
\text { on the right bank of } \\
\text { the river. The river is } \\
\text { overall sinuous with } \\
\text { the presence of small } \\
\text { meander and very } \\
\text { abundant riparian } \\
\text { vegetation }\end{array}$ & 0.052 & 0.537 \\
\hline 4 & $\begin{array}{l}\text { Bedrock: sandstone. } \\
\text { Superficial geology, } \\
\text { sedimentary substrate } \\
\text { of triassic period. } \\
\text { Dominance of fluvial } \\
\text { deposits. }\end{array}$ & $\begin{array}{l}\text { Min grain is mud, } \\
\text { max grain is gravel. } \\
\text { Dominant grain is } \\
\text { sand. Arenaceous - } \\
\text { rudaceous grains. }\end{array}$ & $\begin{array}{l}\text { Mostly unconfined } \\
\text { valley, presence of } \\
\text { homes on the right } \\
\text { bank of the river. The } \\
\text { river is meandering } \\
\text { and abundant riparian } \\
\text { vegetation }\end{array}$ & 0.261 & 1.962 \\
\hline 5 & $\begin{array}{l}\text { Superficial geology of } \\
\text { quaternary period. } \\
\text { Dominance of } \\
\text { glaciofluvial deposit. }\end{array}$ & $\begin{array}{l}\text { Min grain is clay, max } \\
\text { grain is gravel. } \\
\text { Dominant grain is } \\
\text { sand. Arenaceous - } \\
\text { rudaceous grains. }\end{array}$ & $\begin{array}{l}\text { Mostly unconfined } \\
\text { valley, presence of } \\
\text { homes on the left bank } \\
\text { of the river. The river } \\
\text { is forming small } \\
\text { meanders and } \\
\text { abundant riparian } \\
\text { vegetation }\end{array}$ & 0.030 & 0.718 \\
\hline 6 & $\begin{array}{l}\text { Superficial geology of } \\
\text { quaternary period. } \\
\text { Dominance of } \\
\text { glaciofluvial and }\end{array}$ & $\begin{array}{l}\text { Min grain is clay, max } \\
\text { grain is gravel. } \\
\text { Dominant grain is } \\
\text { sand. Arenaceous - }\end{array}$ & $\begin{array}{l}\text { Unconfined valley on } \\
\text { both banks. The river } \\
\text { is meandering and } \\
\text { riparian vegetation is }\end{array}$ & 0.011 & 0.600 \\
\hline
\end{tabular}


Hydrol. Earth Syst. Sci. Discuss., doi:10.5194/hess-2016-683, 2017

Manuscript under review for journal Hydrol. Earth Syst. Sci.

Published: 9 January 2017

(c) Author(s) 2017. CC-BY 3.0 License.

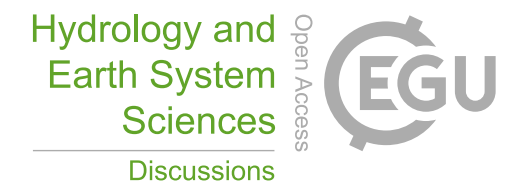

0.06

1.870

grain is

gravel.Dominance of

clay with gravel.

Mixed Argillic

andrudaceous grains.

Min is clay and max is gravel. Mixed arenaceous and argillic grain.

Superficial geology of quaternary period. Dominance of glaciofluvial and alluvial deposit.

9

Superficial geology of quaternary period. Dominance of glaciofluvial and alluvial deposit.

Min is clay and max is gravel Predominance of sand grains.

Unconfined valley on both banks presence of a small bridge. The river is meandering and riparian vegetation is present. Throughout its length although more scarce with comparison to previous sections.

Mostly unconfined valley, presence of industrial plant on the left bank of the river. On the left bank there are two ponds. The river is forming small meanders, riparian vegetation is present.

Unconfined valley on both banks. The river is meandering and riparian vegetation is present and abundant on the left bank.

Presence of pond.

Unconfined valley on

0.012

0.826 quaternary period. Dominance of glaciofluvial and max grain is gravel both banks. The river is mostly sinuous and riparian vegetation is abundant on both fluvial deposit. with presence of silt as well. Mix of arenaceous and banks. 
Hydrol. Earth Syst. Sci. Discuss., doi:10.5194/hess-2016-683, 2017

Manuscript under review for journal Hydrol. Earth Syst. Sci.

Published: 9 January 2017

(c) Author(s) 2017. CC-BY 3.0 License.
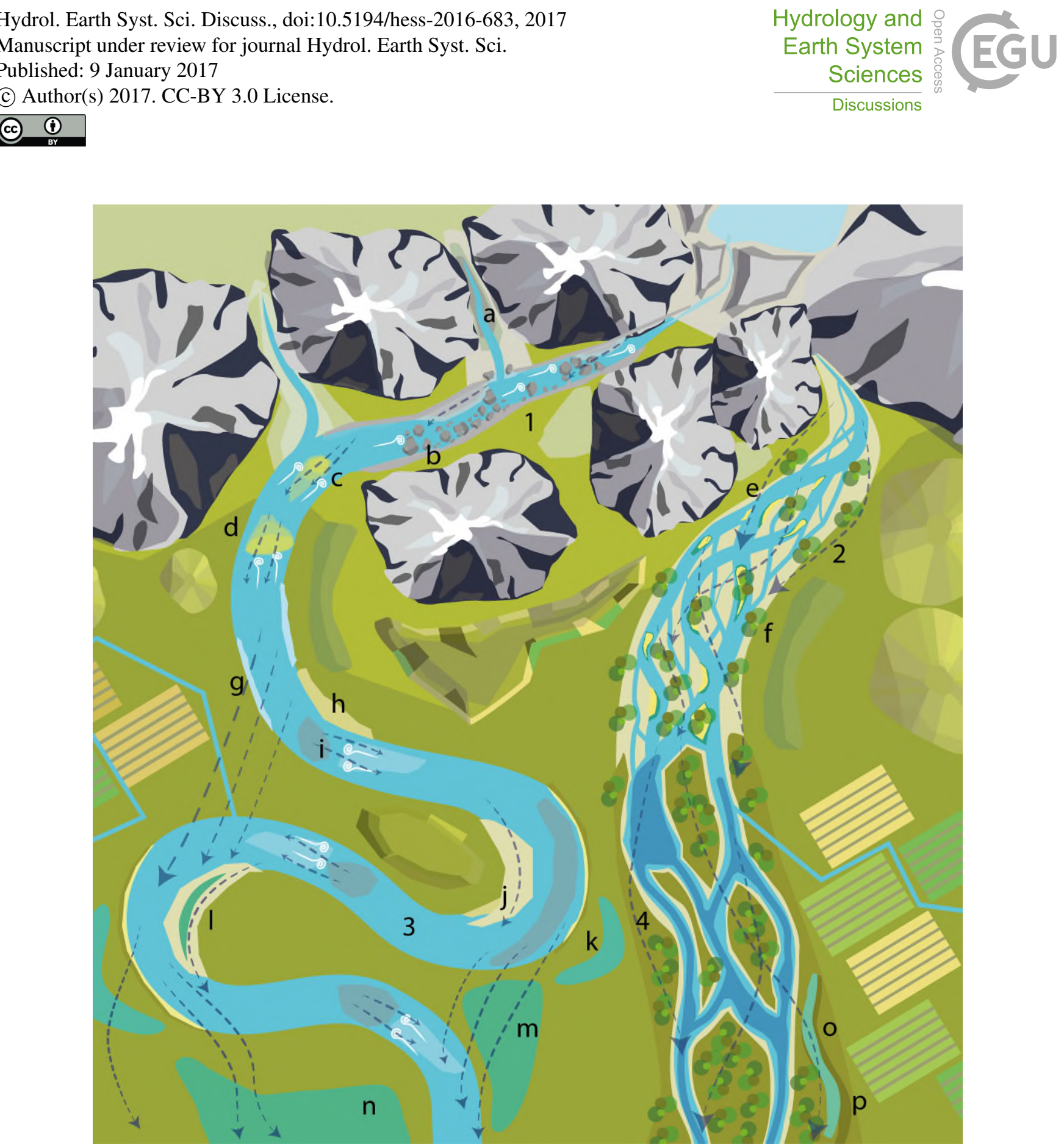

Figure 1: Illustration of catchment complexity: scales and features that influence hyporheic exchange flows. Spatial changes in surface topography, land use and vegetation, drive geomorphological and hydrological changes at valley and reach scale. At catchment scale, variations in surface topography shapes valleys and channel types. Feature 1 refers to confined valleys characterized by straight channels, meandered and braided, and the following floodplain features: scour holes and gravel splays (a). The straight channel presents in-channel cascades (b) geomorphic features. Feature 2 refers to braided channel morphology with multi-thread channel, an undulating floodplain of bars and islands. In-channel geomorphic units are several types of bars (e), such as mid and lateral bars, and vegetated islands (f). Feature 3 represents a sinuous-meandering floodplain with occasional oxbow lakes and backwater swamps $(\mathrm{m}, \mathrm{n}, \mathrm{k})$ and in channel: longitudinal bar (c), transverse bar (d), counterpoint bar (h), pondriffle (i), point bar (l), chute channel (j). Feature 4 indicates an anabranching valley with multi-thread channels including abandoned channels (o) and backwater swamps (p). The channel can be quite deep and include islands covered with vegetation. The symbol * refers to irrigation system of the adjacent agricultural fields. 
Hydrol. Earth Syst. Sci. Discuss., doi:10.5194/hess-2016-683, 2017

Manuscript under review for journal Hydrol. Earth Syst. Sci.

Published: 9 January 2017

(c) Author(s) 2017. CC-BY 3.0 License.
Hydrology and

\section{(c) (P)}

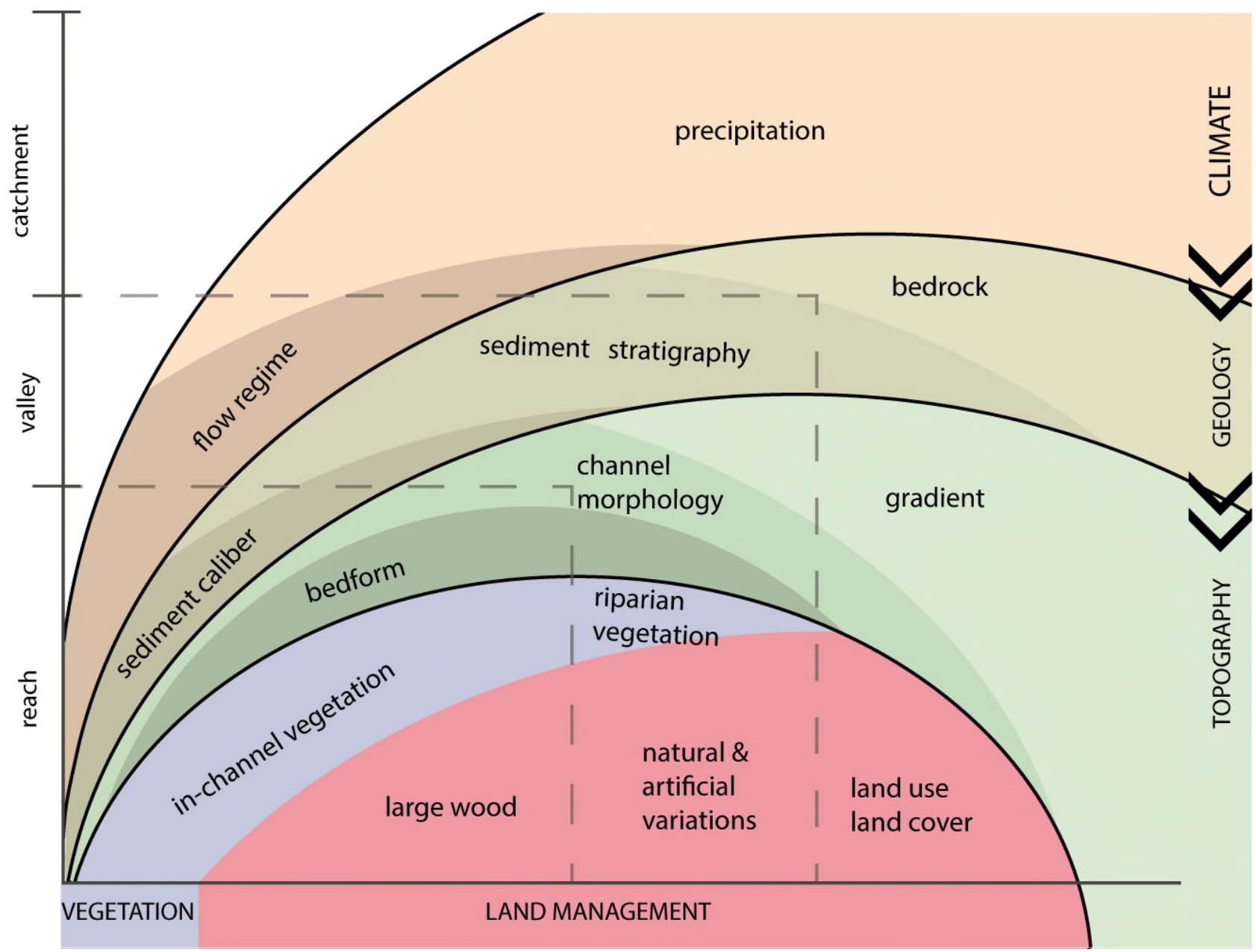

Figure 2: Conceptual diagram of the key factors driving the hyporheic exchange across scales. On the $y$ axis the spatial scales, on the $x$ and secondary $y$ axis the main factors spatially related to the HEF. This diagram can be read from both directions: right to left (top down approach) or left to right (bottom up approach). Color gradient, from light to dark, follows the hierarchical approach of this review (from catchment factors to reach scale ones). Black arrows indicate that processes have mixed drivers (i.e. topography is the combination of geology and climate). 
Hydrol. Earth Syst. Sci. Discuss., doi:10.5194/hess-2016-683, 2017

Manuscript under review for journal Hydrol. Earth Syst. Sci.

Published: 9 January 2017

(c) Author(s) 2017. CC-BY 3.0 License.
Hydrology and

Earth System

Sciences

Discussions

(c) (i)

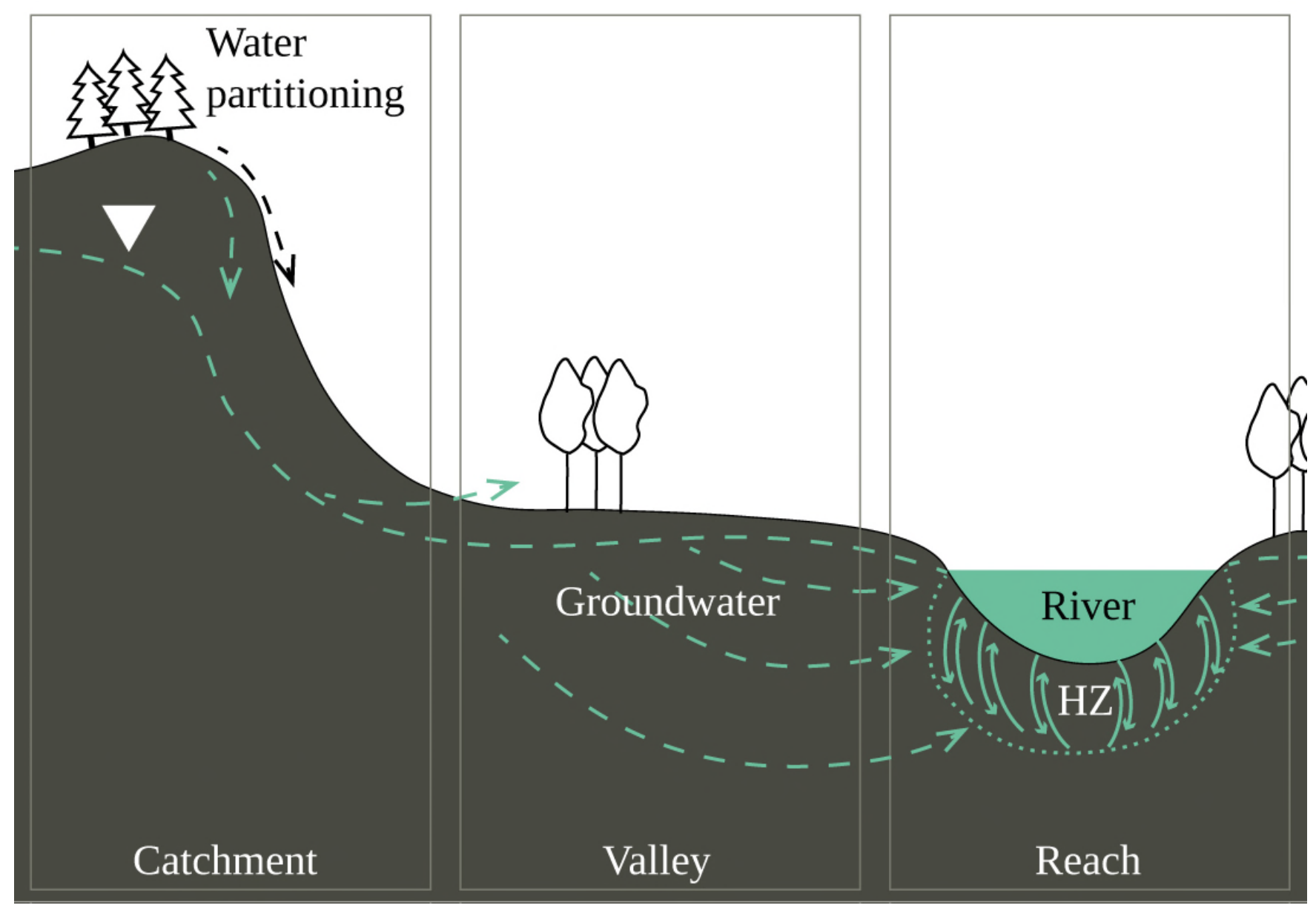

Figure 3: Cross section of the spatial scales considered in this review, from origin and partitioning of water between surface and subsurface flow at catchment scale, to flow through valleys and river channels. 
Hydrol. Earth Syst. Sci. Discuss., doi:10.5194/hess-2016-683, 2017

Manuscript under review for journal Hydrol. Earth Syst. Sci.

Published: 9 January 2017

(c) Author(s) 2017. CC-BY 3.0 License.

\section{Hydrology and

(c) (i)
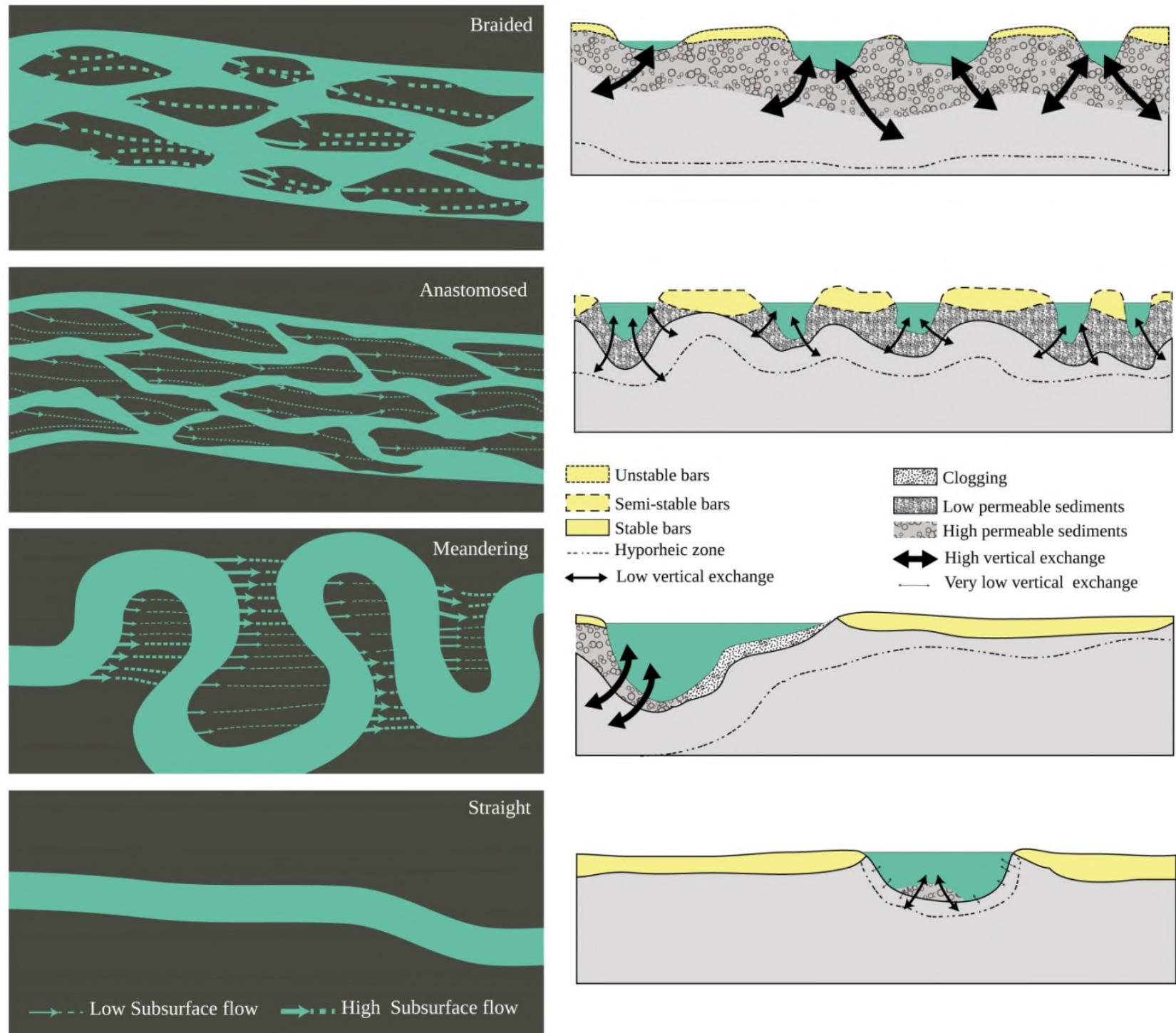

Figure 4: Representation of channel planforms. Sinuosity influences water exchange within a river segment. Hyporheic exchange increases with sinuosity due to hydraulic gradients in the meander neck (Section 4). 
Hydrol. Earth Syst. Sci. Discuss., doi:10.5194/hess-2016-683, 2017

Manuscript under review for journal Hydrol. Earth Syst. Sci.

Published: 9 January 2017
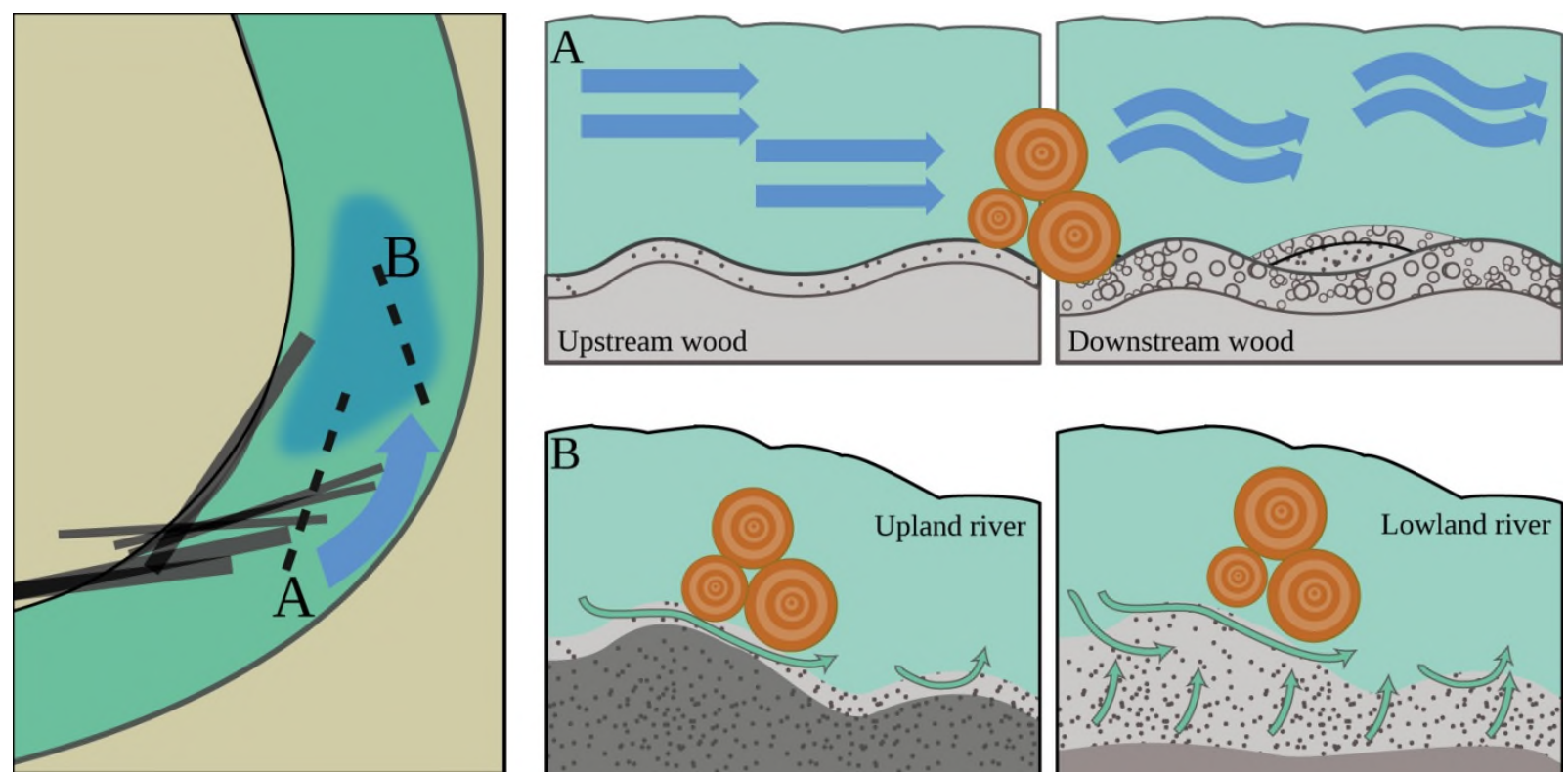

Figure 5: Effects of large wood on hyporheic exchange flows. Effect of wood in upland and lowland rivers (Krause et al., 2014). 
Hydrol. Earth Syst. Sci. Discuss., doi:10.5194/hess-2016-683, 2017

Manuscript under review for journal Hydrol. Earth Syst. Sci.

Published: 9 January 2017

(c) Author(s) 2017. CC-BY 3.0 License.

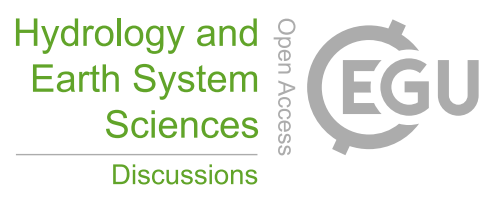

(c) $\underset{\mathrm{BY}}{\mathrm{B}}$

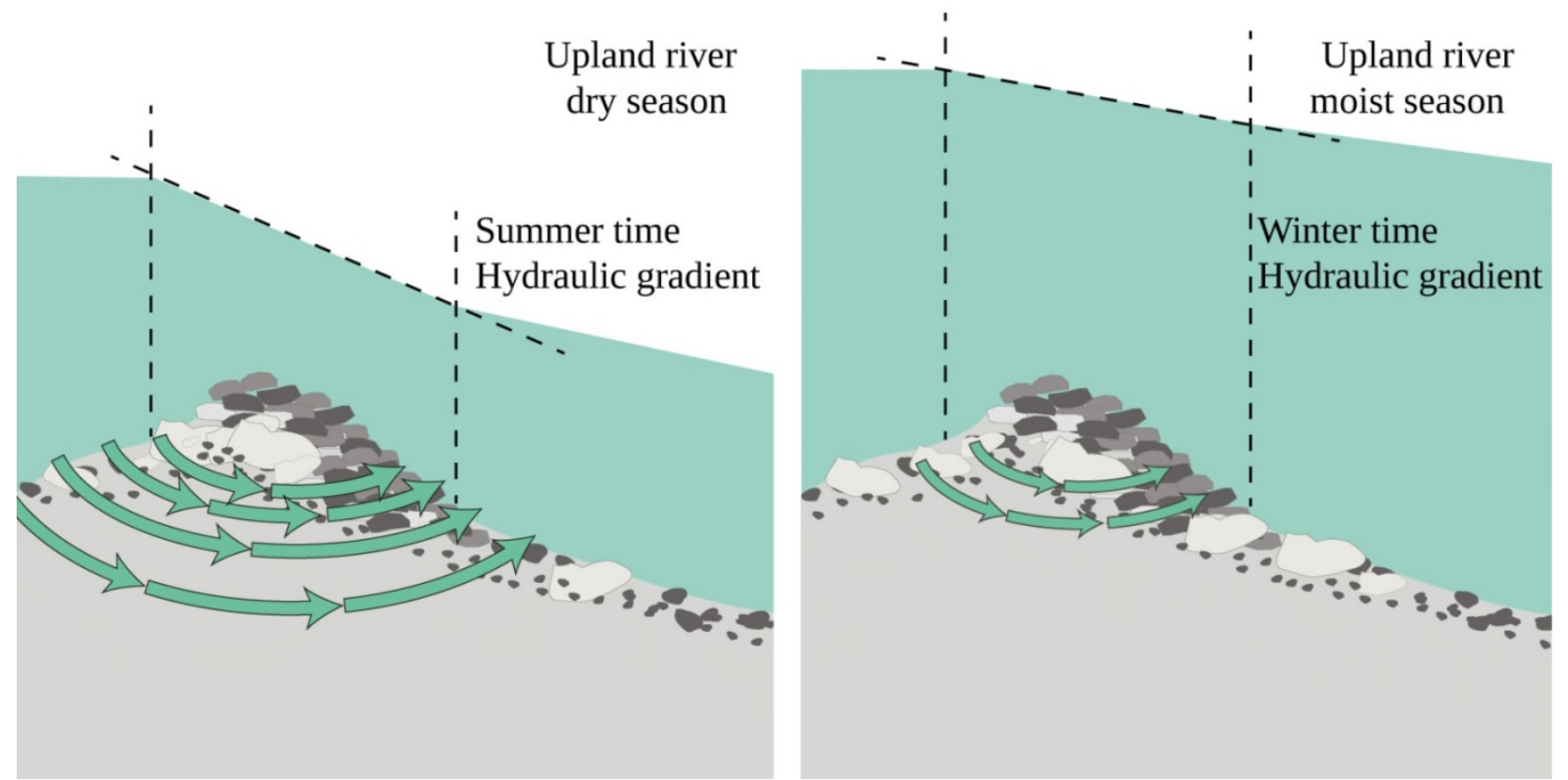

Figure 6: Conceptual representation of seasonal variation of hydraulic gradient with water stages in a upland environment. Development of hyporheic exchange in a riffle considering extension and contraction of hyporheic sediment. 
Hydrol. Earth Syst. Sci. Discuss., doi:10.5194/hess-2016-683, 2017

Manuscript under review for journal Hydrol. Earth Syst. Sci.

Published: 9 January 2017

(c) Author(s) 2017. CC-BY 3.0 License.
Hydrology and

Earth System

Sciences

Discussions

(c) (1)
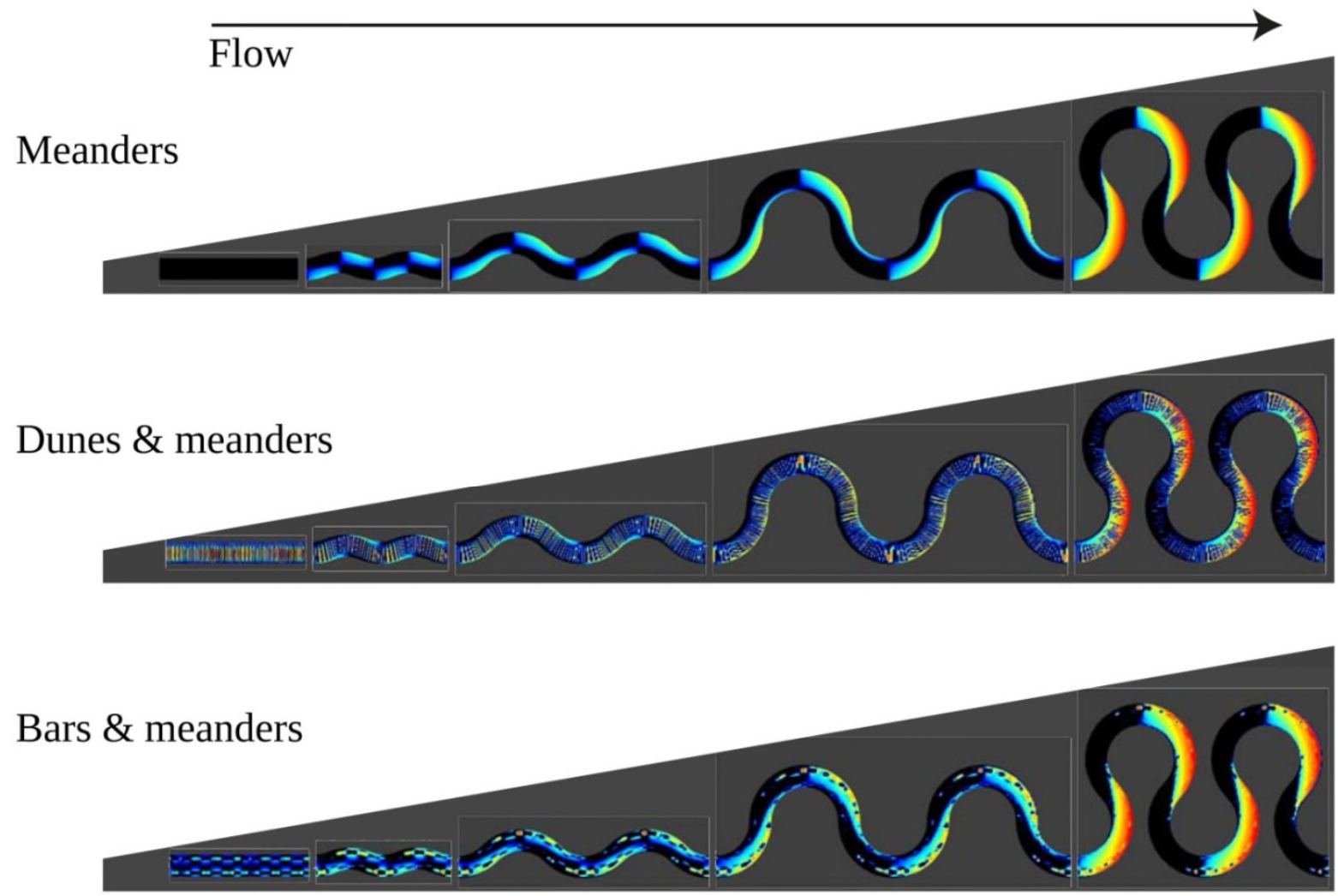

Dunes, Bars \& meanders

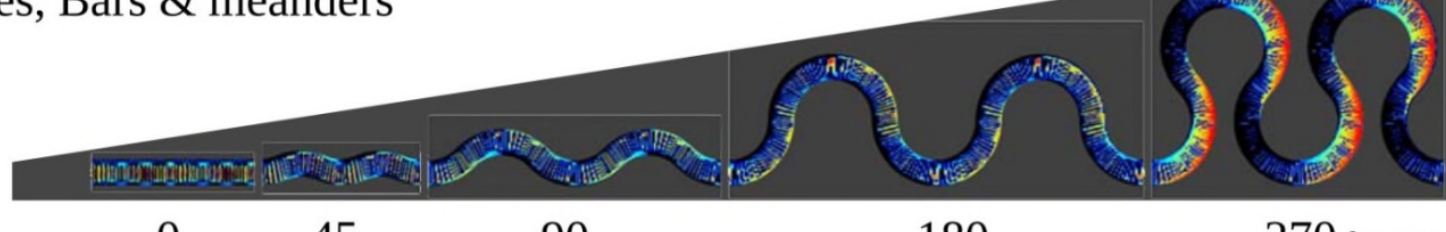

$0 \quad 45$

90

180

270 degrees

Flux into Subsurface (widths/s) \ $\quad$ Flux outoff subsubsurface

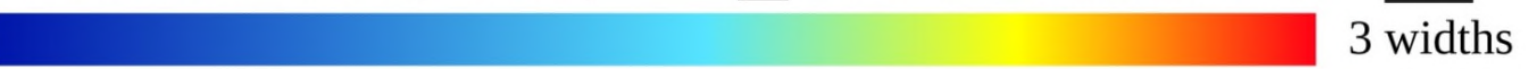

$\begin{array}{lllllllll}-12 & -11 & -10 & -9 & -8 & -7 & -6 & -5 & \times 10^{-6}\end{array}$

Figure 7: Simulation of hyporheic flux associated with superimposed bedforms and meanders. In all topographies, there is large infiltration flux on the downstream side of the meander. In low sinuosity channels, bedforms induce the most hyporheic exchange flows (Figure from Stonedahl et al., 2013). 
Hydrol. Earth Syst. Sci. Discuss., doi:10.5194/hess-2016-683, 2017

Manuscript under review for journal Hydrol. Earth Syst. Sci.

Published: 9 January 2017

(c) Author(s) 2017. CC-BY 3.0 License.
Hydrology and

Earth System

Sciences

Discussions

(C) (1)

$10 \mathrm{~m}$
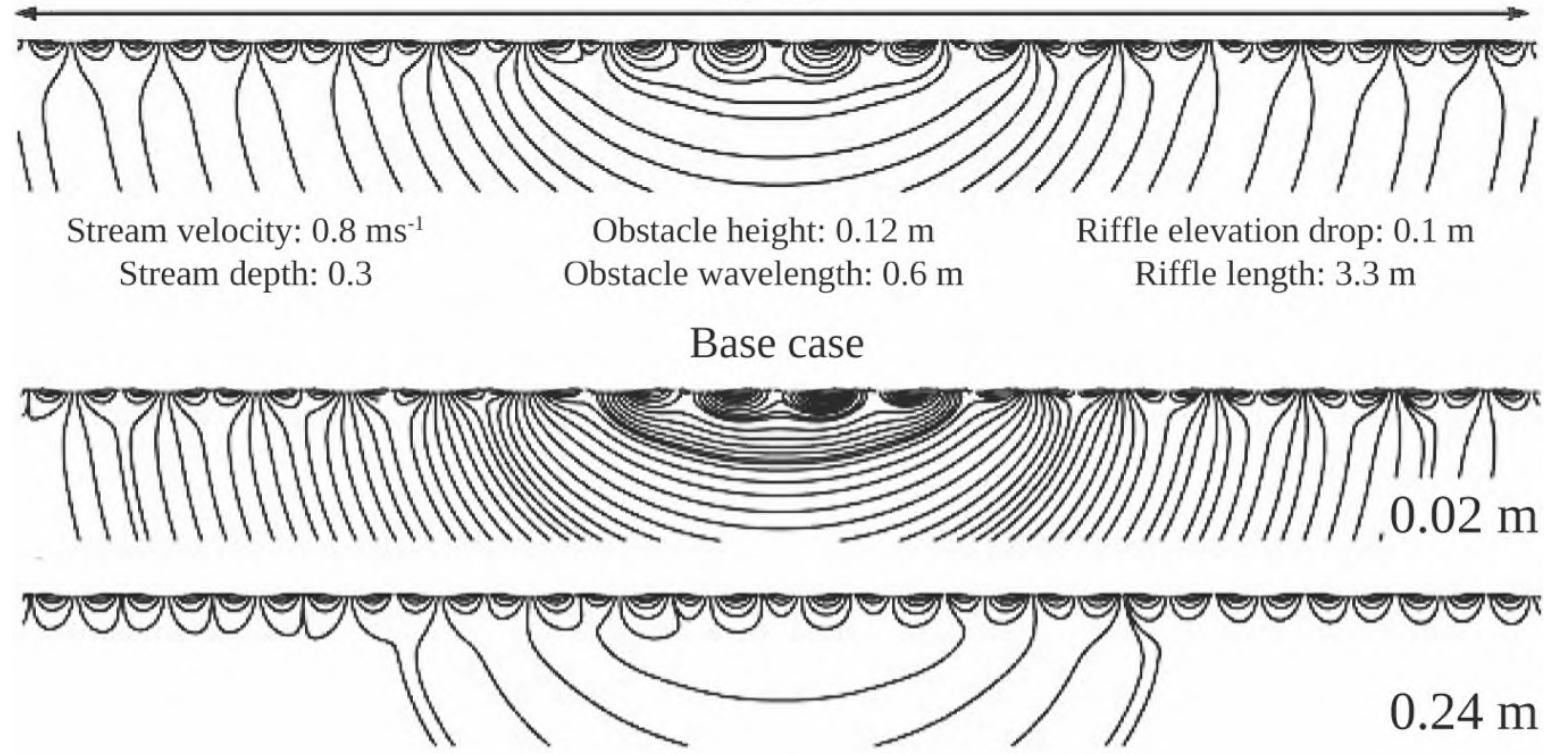

Obstacle (microform) height

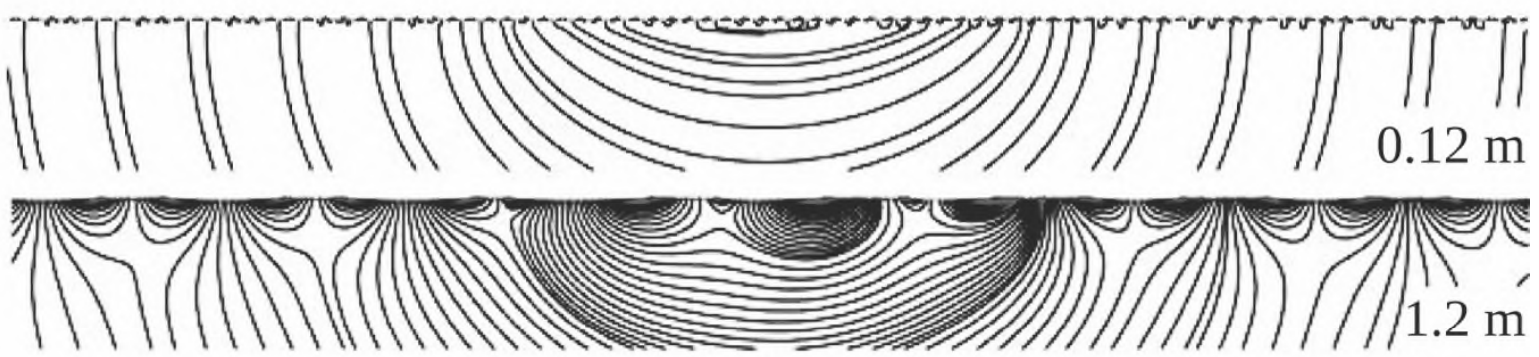

Obstacle (microform) wavelength
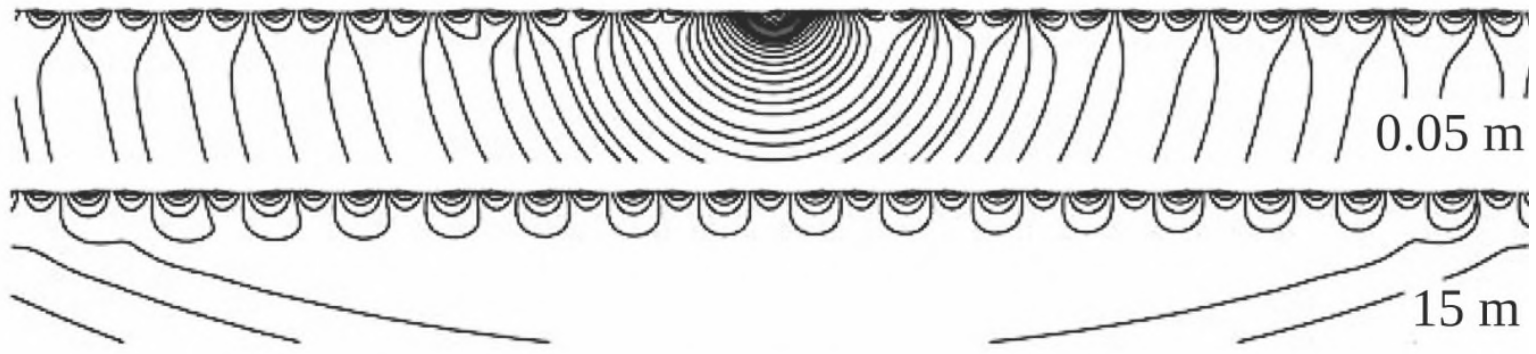

Riffle (macroform) length

Figure 8: Hyporheic exchange flow paths in a pool-riffle-pool sequence. The obstacle height, length and riffle length control the flow patterns (Figure from Kaser et al., 2013). 
Hydrol. Earth Syst. Sci. Discuss., doi:10.5194/hess-2016-683, 2017

Manuscript under review for journal Hydrol. Earth Syst. Sci.

Published: 9 January 2017

(c) Author(s) 2017. CC-BY 3.0 License.
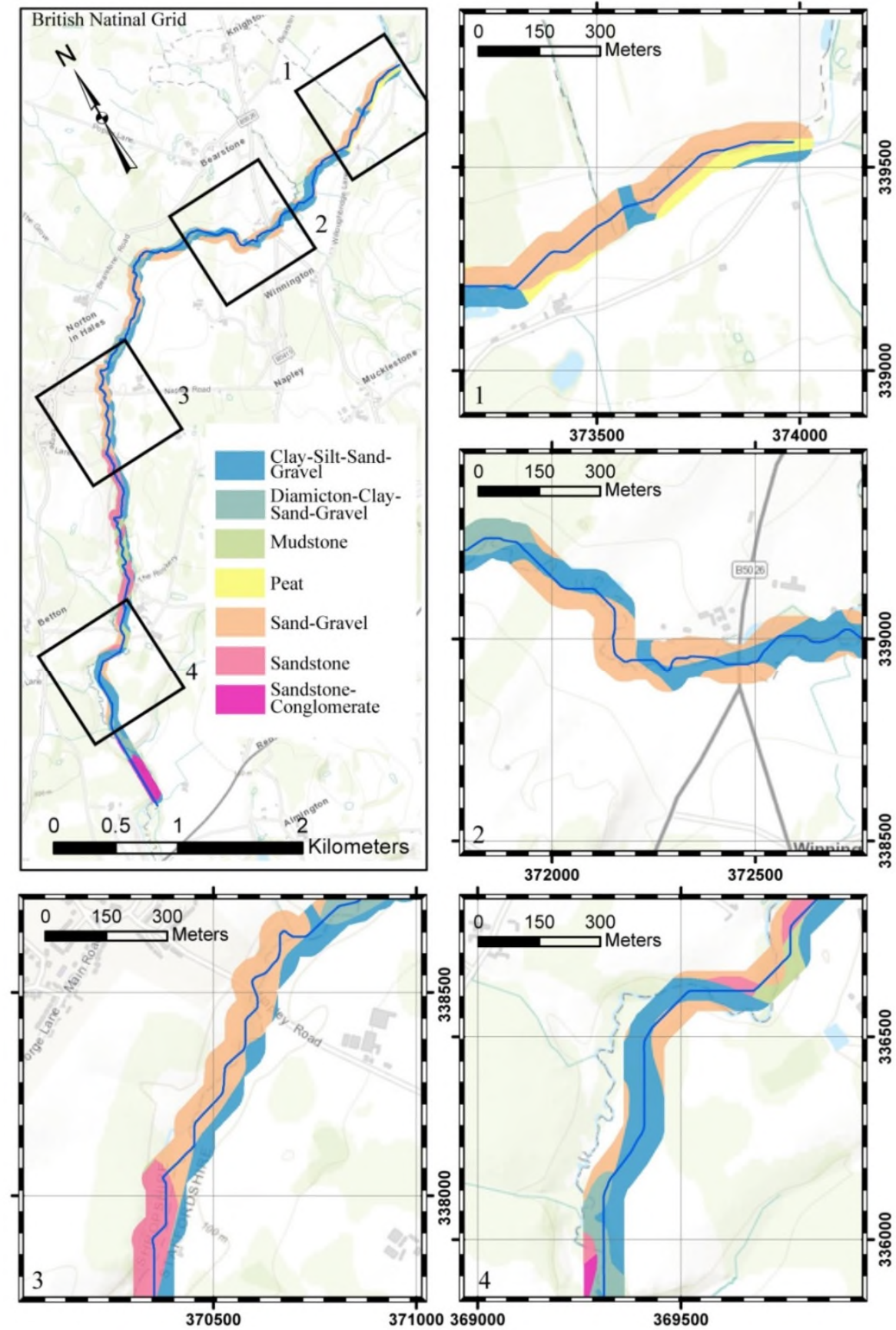

Figure 9: Example of 4 out of 10 reaches identified along the River Tern (Table 3). The river is subdivided into reaches based on their planform morphology (sinuosity units: when the overall direction of the planimetric course changes) and classified in Table 3. This area has also been sampled by Hannah et al. (2009). The figure represents for each reach section, the main river, superficial and bedrock geology in a buffer area of $50 \mathrm{~m}$ from the main channel. 
Hydrol. Earth Syst. Sci. Discuss., doi:10.5194/hess-2016-683, 2017

Manuscript under review for journal Hydrol. Earth Syst. Sci.

Published: 9 January 2017

(c) Author(s) 2017. CC-BY 3.0 License.

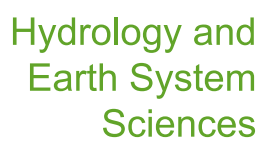

Discussions

\section{References}

Abbe, T. B., \& Montgomery, D. R.: Patterns and processes of wood debris accumulation in the Queets river basin, Washington, Geomorphology,51(1), 81-107, 2003.

Adams, B., Peach, D., and Bloomfield, J.: The LOCAR hydrogeological infrastructure in the tern catchment, Tech. rep., British Geological Survey, 2003.

Allen, D., Brewerton, L., Coleby, L., Gibbs, B., Lewis, M., MacDonald, A., Wagstaff, S., and Williams, A.: The physical properties of major aquifers in England and Wales, Tech. rep., British Geological Survey, 1997.

Anderson, J. K., Wondzell, S. M., Gooseff, M. N., \& Haggerty, R.: Patterns in stream longitudinal profiles and implications for hyporheic exchange flow at the HJ Andrews Experimental Forest, Oregon, USA.Hydrological Processes, 19(15), 29312949, 2005.

Angermann, L., Krause, S., and Lewandowski, J.: Application of heat pulse injections for investigating shallow hyporheic flow in a lowland river, Water Resources Research, 48, 1-16, 2012a.

Angermann, L., Lewandowski, J., Fleckenstein, J. H., and Nützmann, G.: A 3D analysis algorithm to improve interpretation of heat pulse sensor results for the determination of small-scale flow directions and velocities in the hyporheic zone, Journal of Hydrology, 475, 1-11,10 2012b.

Anibas, C., Verbeiren, B., Buis, K., Chormánski, J., De Doncker, L., Okruszko, T., Meire, P., and Batelaan, O.: A hierarchical approach on groundwater-surface water interaction in wetlands along the upper Biebrza River, Poland, Hydrology and Earth System Sciences, 16, 2329-2346, 2012.

20 Arnell, N. and Reynard, N.: The effects of climate change due to global warming on river flows in Great Britain, Journal of hydrology, 183, 397-424, 1996.

Arntzen, E. V., Geist, D. R., and Dresel, P. E.: Effects of fluctuating river flow on groundwater/surface water mixing in the hyporheic zone of a regulated, large cobble bed river, River Research and Applications, 22, 937-946, 2006.

Azinheira, D. L., Scott, D. T., Hession, W., and Hester, E. T.: Comparison of effects of inset floodplains and hyporheic exchange induced by in-stream structures on solute retention, Water Resources Research, 50, 6168-6190, 2014.

Bardini, L., Boano, F., Cardenas, M. B., Revelli, R., and Ridolfi, L.: Nutrient cycling in bedform induced hyporheic zones, Geochimica et Cosmochimica Acta, 84, 47-61, 2012.

Bencala, K. E.: Interactions of solutes and streambed sediment: 2. A dynamic analysis of coupled hydrologic and chemical processes that determine solute transport, Water Resources Research, 20, 1804-1814, 1984.

30 Benda, L., \& Bigelow, P.: On the patterns and processes of wood in northern California streams, Geomorphology,209, 7997, 2014.

Bhaskar, A. S., Harvey, J. W., and Henry, E. J.: Resolving hyporheic and groundwater components of streambed water flux using heat as a tracer, Water Resources Research, 48, 2012.

Birkás, M., Stingli, A., Farkas, Cs., Bottlik, L.: Soil compaction due to cultivation and climate caused yield loss, Návönytermesztös (in Hungarian), 2009.

Bis, Barbara, Anna Zdanowicz, and Maciej Zalewski: Effects of catchment properties on hydrochemistry, habitat complexity and invertebrate community structure in a lowland river. Assessing the Ecological Integrity of Running Waters, Springer Netherlands, 369-387, 2000.

Buis, E., Veldkamp, A.,: Modelling dynamic water redistribution patterns in arid catchments in the Negev Desert of Israel,

Earth Surf. Processes Landforms, 33, 107-122, 2008.

Boano, F., Camporeale, C., Revelli, R., and Ridolfi, L.: Sinuosity-driven hyporheic exchange in meandering rivers, Geophysical Research 35 Letters, 33, 1-4, 2006.

Boano, F., Revelli, R., and Ridolfi, L.: Bedform-induced hyporheic exchange with unsteady flows, Advances in water resources, 30, 148-156, 2007.

45 Boano, F., Revelli, R., and Ridolfi, L.: Reduction of the hyporheic zone volume due to the stream-aquifer interaction, Geophysical Research Letters, 35, 1-5, 2008.

Boano, F., Harvey, J. W., Marion, A., Packman, A. I., Revelli, R., Ridolfi, L., and Wörman, A.: Hyporheic flow and transport processes:Mechanisms, models, and biogeochemical implications, Reviews of Geophysics, 52, 603-679, 2014.

Boulton, A., Marmonier, P., and 5 Davis, J.: Hydrological exchange and subsurface water chemistry in streams varying in salinity in southwestern Australia, International Journal of Salt Lake Research, 8, 361-382, 1999. 
Hydrol. Earth Syst. Sci. Discuss., doi:10.5194/hess-2016-683, 2017

Manuscript under review for journal Hydrol. Earth Syst. Sci.

Published: 9 January 2017

(c) Author(s) 2017. CC-BY 3.0 License.

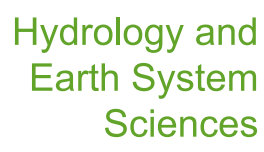

Discussions

Boulton, A. J., Scarsbrook, M. R., Quinn, J. M., and Burrell, G. P.: Land-use effects on the hyporheic ecology of five small streams near Hamilton, New Zealand, New Zealand journal of marine and freshwater research, 31, 609-622, 1997.

Boulton, A. J., Findlay, S., Marmonier, P., Stanley, E. H., and Valett, H. M.: The functional significance of the hyporheic zone in streams and rivers, Annual Review of Ecology and Systematics, pp. 59-81, 1998.

Bourke, S. a., Cook, P. G., Shanafield, M., Dogramaci, S., and Clark, J. F.: Characterisation of hyporheic exchange in a losing stream using radon-222, Journal of Hydrology, 519, 94-105, http://dx.doi.org/10.1016/j.jhydrol.2014.06.057, 2014.

Briggs, M. a., Gooseff, M. N., Arp, C. D., and Baker, M. a.: A method for estimating surface transient storage parameters for streams with concurrent hyporheic storage, Water Resources Research, 46, 1-13, doi:10.1029/2008WR006959, 2010.

British Geological Survey. http://www.bgs.ac.uk/products/digitalmaps/DiGMapGB_50.html, accessed on October 2016.

Brunke, M. and Gonser, T.: The ecological significance of exchange processes between rivers and groundwater, Freshwater biology, 37, 1-33, 1997.

Buffington, J. M. and Tonina, D.: Hyporheic exchange in mountain rivers II: Effects of channel morphology on mechanics, scales, and rates of exchange, Geography Compass, 3, 1038-1062, 2009.

Cardenas, B. M. and Wilson, J. L.: The influence of ambient groundwater discharge on exchange zones induced by currentbedform interactions, Journal of Hydrology, 331, 103-109, 2006.

Cardenas, M. B.: The effect of river bend morphology on flow and timescales of surface water-groundwater exchange across pointbars, Journal of Hydrology, 362, 134-141, 2008a.

Cardenas, M. B.: Surface water-groundwater interface geomorphology leads to scaling of residence times, Geophysical Research Letters, 35,2008b.

20 Cardenas, M. B.: A model for lateral hyporheic flow based on valley slope and channel sinuosity, Water Resources Research, 45, 1-5, 2009a.

Cardenas, M. B.: Stream-aquifer interactions and hyporheic exchange in gaining and losing sinuous streams, Water Resources Research, 45,1-13, 2009b.

Cardenas, M. B. and Wilson, J. L.: Effects of current-bed form induced fluid flow on the thermal regime of sediments,

Water resources research, 43, 2007.

Cardenas, M. B., Wilson, J. L., and Zlotnik, V. a.: Impact of heterogeneity, bed forms, and stream curvature on subchannel hyporheic exchange, Water Resources Research, 40, 1-14, doi:10.1029/2004WR003008, 2004.

Carrillo-Rivera, J. J., Cardona, A., Huizar-Alvarez, R., \& Graniel, E.: Response of the interaction between groundwater and other components of the environment in Mexico, Environmental Geology, 55(2), 303-319, 2008.

30 Caruso, A., Ridolfi,L.,Boano, F.: Impact of watershed topography on hyporheic exchange. Advances in Water Resources, 2016.

Champion, P. D. and Tanner, C. C.: Seasonality of macrophytes and interaction with flow in a New Zealand lowland stream, Hydrobiologia, 35 441, 1-12, 2000.

Chen, Y., Deng, H., Li, B., Li, Z., \& Xu, C.: Abrupt change of temperature and precipitation extremes in the arid region of

Northwest China, Quaternary International,336, 35-43, 2014.

Cho, J., Barone, V. A., \& Mostaghimi, S.: Simulation of land use impacts on groundwater levels and streamflow in a Virginia watershed, Agricultural water management, 96(1), 1-11, 2009.

Cirmo CP, McDonnell JJ: Linking the hydrologic and biogeochemical controls of nitrogen transport in near-stream zones of temperate-forested catchments: a review, J Hydrol, 199:88-120, 1997.

40 Clay, A., Bradley, C., Gerrard, A., and Leng, M.: Using stable isotopes of water to infer wetland hydrological dynamics, Hydrology and Earth System Sciences, 8, 1164-1173, 2004.

Collins, B. D., Montgomery, D. R., \& Haas, A. D. : Historical changes in the distribution and functions of large wood in Puget Lowland rivers, Canadian Journal of Fisheries and Aquatic Sciences,59(1), 66-76, 2002.

Corbett, C.W., M.Wahl, D.E. Porter, D. Edwards, and C. Moise,: Nonpoint source runoff modeling: a comparison of a forested watershed and an urban watershed on the South Carolina coast. Journal of Experimental Marine Biology and Ecology 213:133-149, 1997.

Corenblit, D., Tabacchi, E., Steiger, J., and Gurnell, A. M.: Reciprocal interactions and adjustments between fluvial landforms and vegetation dynamics in river corridors: a review of complementary approaches, Earth-Science Reviews, 84, 56-86, 2007. 
Hydrol. Earth Syst. Sci. Discuss., doi:10.5194/hess-2016-683, 2017

Manuscript under review for journal Hydrol. Earth Syst. Sci.

Published: 9 January 2017

(c) Author(s) 2017. CC-BY 3.0 License.

Cranswick, R. H. and Cook, P. G.: Scales and magnitude of hyporheic, river-aquifer and bank storage exchange fluxes, Hydrological Processes, 3097, n/a-n/a, 2015.

Crenshaw, C., Grimm, N., Zeglin, L., Sheibley, R., Dahm, C., and Ershall, A.: Dissolved inorganic nitrogen dynamics in the hyporheic zone of reference and human-altered southwestern US streams, Fundamental and Applied Limnology/Archiv für Hydrobiologie, 176, 391-405, 2010.

Creuzé des Chatelliers, M., D. Poinsart, and J.-P. Bravard: Geomorphology of alluvial groundwater ecosystems. Pages 157185 in J. Gibert, D. L. Danielopol, and J. A. Stanford (eds.), Groundwater ecology. Academic Press, San Diego, 1994.

Dahm, C.L., N.B. Grimm, P. Marmonier, H.M. Valett, and P. Ver- vier:. Nutrient Dynamics at the Interface Between Surface Waters and Groundwaters. Freshwater Biology 40:427-451, 1998.

10 D'angelo, D.,Webster, J., Gregory, S., and Meyer, J.: Transient storage in Appalachian and Cascade mountain streams as related to hydraulic characteristics, Journal of the North American Benthological Society, pp. 223-235, 1993.

Darboux, F., Davy, P., Gascuel-Odoux, C.,: Effect of depression storage capacity on overland flow generation for rough horizontal surfaces, Earth Surf. Processes Landforms 27, 177-191, 2002.

Davidson, S. L., \& Eaton, B. C.: Modeling channel morphodynamic response to variations in large wood: Implications for stream rehabilitation in degraded watersheds, Geomorphology, 202, 59-73, 2013.

Dent, C. L., Grimm, N. B., Martí, E., Edmonds, J. W., Henry, J. C., \& Welter, J. R.: Variability in surface subsurface hydrologic interactions and implications for nutrient retention in an arid land stream, Journal of Geophysical Research: Biogeosciences, 112(G4), 2007.

Devito, K., and Smerdon, B.: A framework for broad-scale classification of hydrologic response units on the Boreal Plain: Is topography the last thing to consider?, Hydrological Processes, 19, 2005.

Didoné, E. J., Minella, J. P. G., Reichert, J. M., Merten, G. H., Dalbianco, L., de Barrros, C. A. P., \& Ramon, R.:Impact of no-tillage agricultural systems on sediment yield in two large catchments in Southern Brazil, Journal of soils and sediments,14(7), 1287-1297,2014.

Dragoni, Walter, and Balbir S. Sukhija: Climate change and groundwater: a short review. Geological Society, London, Special Publications, 1, 1-12, 2008.

Duke, J. R., White, J. D., Allen, P. M., and Muttiah, R. S.: Riparian influence on hyporheic-zone formation downstream of a small dam in the Blackland Prairie region of Texas, Hydrological Processes, 21, 141-150, doi:10.1002/hyp, 2007.

Elliott, A. H. and Brooks, N. H.: Transfer of nonsorbing solutes to a streambed with bed forms: Laboratory experiments, Water Resources Research, 33, 137-151, 1997.

30 Ellis, P. A., Mackay, R., \& Rivett, M. O: Quantifying urban river-aquifer fluid exchange processes: a multi-scale problem, Journal of Contaminant Hydrology, 91(1), 58-80, 2007.

Elmi, A. A., Madramootoo, C., Egeh, M., Liu, A., and Hamel, C.: Environmental and agronomic implications of water table and nitrogen fertilization management, Journal of environmental quality, 31, 1858-1867, 2002.

Ensign, S. H., \& Doyle, M. W. :In-channel transient storage and associated nutrient retention: Evidence from experimental manipulations, Limnology and Oceanography, 50(6), 1740-1751, 2005.

Fanelli, R. M., \& Lautz, L. K.: Patterns of water, heat, and solute flux through streambeds around small dams, Ground Water,46(5), 671-687, 2008.

Fryirs, Kirstie A., Joseph M. Wheaton, and Gary J. Brierley: An approach for measuring confinement and assessing the influence of valley setting on river forms and processes, Earth Surface Processes and Landforms, 2016.

40 Fox, A., Boano, F., and Arnon, S.: Impact of losing and gaining streamflow conditions on hyporheic exchange fluxes induced by dune-shaped bed forms, Water Resources Research, 50, 1895-1907, 2014.

Freeze, R. A. and Witherspoon, P.: Theoretical analysis of regional groundwater flow: 2. Effect of water-table configuration and subsurface permeability variation, Water Resources Research, 3, 623-634, 1967.

Fuller, R., Smith, G., Sanderson, J., Hill, R., Thomson, A., Cox, R., Brown, N., Clarke, R., Rothery, P., and Gerard, F.: Countryside Survey 2000 Module 7. Land Cover Map 2000. Final Report, Tech. rep., NERC/Centre for Ecology and Hydrology, 2002.

Gallo, E. L., Meixner, T., Aoubid, H., Lohse, 5 K. A., and Brooks, P. D.: Combined impact of catchment size, land cover, and precipitation on streamflow and total dissolved nitrogen: A global comparative analysis, Global Biogeochemical Cycles, 29, 1109-1121, 2015. 
Hydrol. Earth Syst. Sci. Discuss., doi:10.5194/hess-2016-683, 2017

Manuscript under review for journal Hydrol. Earth Syst. Sci.

Published: 9 January 2017

(c) Author(s) 2017. CC-BY 3.0 License.

Gariglio, F. P., Tonina, D., and Luce, C. H.: Spatiotemporal variability of hyporheic exchange through a pool-riffle-pool sequence, Water Resources Research, 49, 7185-7204, 2013.

Gilbert, J., Dole-Olivier, M., Marmonier, P., and Vervier, P.: Surface water-groundwater ecotones, IN: The Ecology and Management of Aquatic-Terrestrial Ecotones. The Parthenon Publishing Group, Carnforth, England. 1990. p 199-225. 9 fig, 1 tab, 90 ref., 1990.

Gleeson, T., Befus, K. M., Jasechko, S., Luijendijk, E., \& Cardenas, M. B.: The global volume and distribution of modern groundwater, Nature Geoscience, 9(2), 161-167, 2016.

Golmohammadi, G., Rudra, R. P., Prasher, S. O., Madani, A., Goel, P. K., \& Mohammadi, K.: Modeling the impacts of tillage practices on water table depth, drain outflow and nitrogen losses using DRAINMOD, Computers and Electronics in Agriculture, 124, 73-83, 2016.

Gomez-Velez, J. D.,Wilson, J. L., and Cardenas, M. B.: Residence time distributions in sinuosity-driven hyporheic zones and their biogeochemical effects, Water Resources Research, 48, 2012.

Gomez-Velez, J. D. and Harvey, J. W.: A hydrogeomorphic river network model predicts where and why hyporheic exchange is important in large basins, Geophysical Research Letters, 41, 6403-6412, 2014.

Gomi, T., Sidle, R. C., and Richardson, J. S.: Understanding Processes and Downstream Linkages of Headwater Systems Headwaters differ from downstream reaches by their close coupling to hillslope processes, more temporal and spatial variation, and their need for different means of protection from land use, BioScience, 52, 905-916, 2002.

Gooseff, M. N., McKnight, D. M., Runkel, R. L., and Vaughn, B. H.: Determining long time-scale hyporheic zone flow paths in Antarctic streams, Hydrological Processes, 17, 1691-1710, 2003.

Gooseff, M. N., Hall, R. O., and Tank, J. L.: Relating transient storage to channel complexity in streams of varying land use in Jackson Hole,Wyoming, Water Resources Research, 43, n/a-n/a, 2007.

Greer, R. C., Wu, J. Q., Singh, P., \& McCool, D. K. : WEPP simulation of observed winter runoff and erosion in the US Pacific Northwest, Vadose Zone Journal, 5(1), 261-272, 2006.

Gregory SV, Swanson FJ,McKee WA.:.An ecosystem perspective of ri- parian zones. BioScience 40: 540-551, 1991.

Gregory, S., Boyer, K. L., Gurnell, A. M., et al.: The ecology and management of wood in world rivers, American Fisheries Society Bethesda, Maryland, 2003.

Grimm, N. B., R. W. Sheibley, C. L. Crenshaw, C. N. Dahm, W. J. Roach, and L. H. Zeglin: N retention and transformation in urban streams, Journal of the North American Benthological Society, 24, 626-642, 2005.

Groffman, P. M., A. M. Dorsey, and P. M. Mayer: N processing within geomorphic structures in urban streams, J. North

Am. Benthol. Soc., 24, 613-625, 2005.

Gulley, J., Martin, J. B., Screaton, E. J., and Moore, P. J.: River reversals into karst springs: A model for cave enlargement in eogenetic karst aquifers, Geological Society of America Bulletin, 123, 457-467, 2011.

Gurnell, A. M., Petts, G. E., Hannah, D. M., Smith, B. P., Edwards, P. J., Kollmann, J., ... \& Tockner, K: Riparian vegetation and island formation along the gravel-bed Fiume Tagliamento, Italy, Earth Surface Processes and Landforms,26(1), 31-62,

2001.

Gurnell, A. M., Piegay, H., Swanson, F. J., \& Gregory, S. V. : Large wood and fluvial processes, Freshwater Biology,47(4), 601-619, 2002.

Gurnell, A. M., Rinaldi, M., Belletti, B., Bizzi, S., Blamauer, B., Braca, G., Buijse, A., Bussettini, M., Camenen, B., Comiti, F., et al.: A multi-scale hierarchical framework for developing understanding of river behaviour to support river management, Aquatic Sciences, 78,1-16, 2016.

Hakenkamp, C. C., Valett, H. M., and Boulton, A. J.: Perspectives on the hyporheic zone: integrating hydrology and biology. Concluding remarks, Journal of the North American Benthological Society, pp. 94-99, 1993.

Hancock, P. J.: Human impacts on the stream-groundwater exchange zone, Environmental Management, 29, 763-781, 2002. Hannah, D. M., Malcolm, I. A., and Bradley, C.: Seasonal hyporheic temperature dynamics over riffle bedforms, Hydrological Processes, 23, 2178-2194, 2009.

Heppell, C. M., Wharton, G., Cotton, J. A. C., Bass, J. A. B., \& Roberts, S. E.: Sediment storage in the shallow hyporheic of lowland vegetated river reaches, Hydrological processes, 23(15), 2239-2251, 2009.

Hartwig, M. and Borchardt, D.: Alteration of key hyporheic functions through biological and physical clogging along a nutrient and fine sediment gradient, Ecohydrology, 8, 961-975, 2015. 
Hydrol. Earth Syst. Sci. Discuss., doi:10.5194/hess-2016-683, 2017

Manuscript under review for journal Hydrol. Earth Syst. Sci.

Published: 9 January 2017

(c) Author(s) 2017. CC-BY 3.0 License.

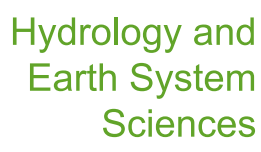

Discussions

Harvey, J. and Gooseff, M.: River corridor science: Hydrologic exchange and ecological consequences from bedforms to basins, Water Resources Research, 51, 6893-6922, 2015.

Harvey, J. W. and Bencala, K. E.: The effect of streambed topography on surface-subsurface water exchange in mountain catchments, Water Resources Research, 29, 89-98, 1993.

Harvey, J. W. and Wagner, B. J.: Quantifying hydrologic interactions between streams and their subsurface hyporheic zones, vol. Streams and ground waters, pp. 3-44, Academic Press, 2000.

Harvey, J. W., Conklin, M. H., and Koelsch, R. S.: Predicting changes in hydrologic retention in an evolving semi-arid alluvial stream,Advances in Water Resources, 26, 939-950, doi:10.1016/S0309-1708(03)00085-X, 2003.

Hassan, M. A., Tonina, D., Beckie, R. D., and Kinnear, M.: The effects of discharge and slope on hyporheic flow in steppool morphologies, Hydrological Processes, 29, 419, 2015.

Hester, E. T. and Cranmer, E. N.: Variation of Hyporheic Potential among Urban Region Streams: Implications for Stream Restoration,Environmental \& Engineering Geoscience, 20, 287-304, 2014.

Hester, E. T. and Doyle, M. W.: In-stream geomorphic structures as drivers of hyporheic exchange, Water Resources Research, 44,30 doi:10.1029/2006WR005810, 2008.

15 Hester, E. T. and Gooseff, M. N.: Moving beyond the banks: Hyporheic restoration is fundamental to restoring ecological services and functions of streams, Environmental Science and Technology, 44, 1521-1525, 2010.

Hester, E. T., Doyle, M. W., and Piehler, M. F.: Impact of Geomorphic Structures on Hyporheic Exchange , Temperature , and Ecological Processes in Streams, 2008.

Hill, A. R., Labadia, C. F., Sanmugadas, K.: Hyporheic zone hydrology and nitrogen dynamics in relation to the streambed topography of a N-rich stream. Biogeochemistry 42:285-310, 1998.

Hill, A. R., et al.: Subsurface denitrification in a forest riparian zone: Interactions between hydrology and supplies of nitrate and organic car- bon, Biogeochemistry, 51, 193-223, doi:10.1023/A:1006476514038, 2000.

Hiscock, K.: Hydrogeology: Principles and Practice, Blackwell publishing, Oxford, 2007.

Hlavcova, K. and Cunderlik, J.: Impact of climate change on the seasonal distribution of runoff in mountainous basins in

Slovakia, IAHS Publications-Series of Proceedings and Reports-Intern Assoc Hydrological Sciences, 248, 39-46, 1998.

Holmes, R. M., Jones Jr, J. B., Fisher, S. G., and Grimm, N. B.: Denitrification in a nitrogen-limited stream ecosystem, Biogeochemistry, 33, 125-146, 1996.

Hynes, H.: The stream and its valley, Verhandlungen der Internationalen Vereinigung fur theoretische und angewandte Limnologie, 19, 1-15,1975.

30 Ibrahim, T., Thornton, S., and Wainwright, J.: Interplay of geomorphic and hydrogeologic features at reach-and channel unit-scales on riverbed hydrology and hydrochemistry: a conceptual model in the Lower Coal Measures, South Yorkshire, UK, Hydrogeology journal, 18, 1391-1411, 2010.

Irvine, D. J., Cranswick, R. H., Simmons, C. T., Shanafield, M. A., and Lautz, L. K.: The effect of streambed heterogeneity on groundwatersurface water exchange fluxes inferred from temperature time series, Water Resources Research, 51, 198$212,2015$.

Jacobson, R. B. and Gran, K. B.: Gravel sediment routing from widespread, low-intensity landscape disturbance, Current River Basin,Missouri, Earth Surface Processes and Landforms, 24, 897-917, 1999.

Jalota, S. K., Sood, A., Chahal, G. B. S., \& Choudhury, B. U. :Crop water productivity of cotton (Gossypium hirsutum L.)wheat (Triticum aestivum L.) system as influenced by deficit irrigation, soil texture and precipitation, Agricultural water management, 84(1), 137-146, 2006

Jeffries, R., Darby, S. E., and Sear, D. A.: The influence of vegetation and organic debris on flood-plain sediment dynamics: case study of a low-order stream in the New Forest, England, Geomorphology, 51, 61-80, 2003.

Jencso, K. G. and McGlynn, B. L.: Hierarchical controls on runoff generation: Topographically driven hydrologic connectivity, geology, and vegetation, Water Resources Research, 47, 2011.

45 Jencso, K. G., McGlynn, B. L., Gooseff, M. N., Wondzell, S. M., Bencala, K. E., and Marshall, L. A.: Hydrologic connectivity between landscapes and streams: Transferring reach-and plot-scale understanding to the catchment scale, Water Resources Research, 45, 2009.

Jones, J. B., S. G. Fisher, and N. B. Grimm: Nitrification in the hyporheic zone of a desert stream ecosystem, J. N. Am. Benthol. Soc., 14, 249-258, 1995. 
Hydrol. Earth Syst. Sci. Discuss., doi:10.5194/hess-2016-683, 2017

Manuscript under review for journal Hydrol. Earth Syst. Sci.

Published: 9 January 2017

(c) Author(s) 2017. CC-BY 3.0 License.

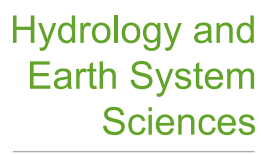

Discussions

Jones, K. L., Poole, G. C., Woessner, W. W., Vitale, M. V., Boer, B. R., O’Daniel, S. J., Thomas, S. A., and Geffen, B. A.: Geomorphology,hydrology, and aquatic vegetation drive seasonal hyporheic flow patterns across a gravel-dominated floodplain, Hydrological Processes, 20 22, 2105-2113, 2008.

Kalantari, Z., Lyon, S. W., Folkeson, L., French, H. K., Stolte, J., Jansson, P.-E., and Sassner, M.: Quantifying the hydrological impact of simulated changes in land use on peak discharge in a small catchment, Science of the Total Environment, 466, 741-754, 2014.

Karwan DL, Saiers JE: Influences of seasonal flow regime on the fate and transport of fine particles and a dissolved solute in a New England stream, Water Resour Res 45, 2009.

Kasahara, T. and Hill, A. R.: Hyporheic exchange flows induced by constructed riffles and steps in lowland streams in southern Ontario,Canada, Hydrological Processes, 20, 4287-4305, 2006.

Kasahara, T. and Hill, A. R.: Lateral hyporheic zone chemistry in an artificially constructed gravel bar and a re-meandered stream channel,Southern Ontario, Canada, Journal of the American Water Resources Association, 43, 1257-1269, 2007.

Kasahara, T. and Hill, A. R.: Modeling the effects of lowland stream restoration projects on stream-subsurface water exchange, Ecological Engineering, 32, 310-319, 2008.

15 Kasahara, T. and Wondzell, S.: Geomorphic controls on hyporheic exchange flow in mountain streams, Water Resources Research, 39, 1-14,30 doi:10.1029/2002WR001386, 2003.

Kasahara, T., Yasuda, Y., and Otsuki, K.: Changes in distribution of fine sediments in the hyporheic zone during high flow events, in: AGU Fall Meeting Abstracts, vol. 1, p. 1444, 2013.

Käser, D. and Hunkeler, D.: Contribution of alluvial groundwater to the outflow of mountainous catchments, Water 20 Resources Research, 2016.

Käser, D., Binley, A., and Heathwaite, A.: On the importance of considering channel microforms in groundwater models of hyporheic exchange, River Research and Applications, 29, 528-535, 2013.

Käser, D. H., Binley, A., Krause, S., and Heathwaite, A. L.: Prospective modelling of 3D hyporheic exchange based on highresolution topography and stream elevation, Hydrological Processes, 28, 2579-2594, 2014.

25 Kiel, B. A. and Cardenas, M. B.: Lateral hyporheic exchange throughout the Mississippi River network, Nature Geoscience, 7, 413-417,2014.

Kjellin, J., Hallin, S., \& Wörman, A.: Spatial variations in denitrification activity in wetland sediments explained by hydrology and denitrifying community structure, Water Research, 41(20), 4710-4720, 2007.

Krause, S.: The impact 5 of structural streambed heterogeneity on groundwater-surface water exchange fluxes and nitrogen metabolism within the hyporheic zone, in: Geophysical Research Abstracts, vol. 9, p. 04087, 2007.

Krause, S., Hannah, D., Fleckenstein, J., Heppell, C., Kaeser, D., Pickup, R., Pinay, G., Robertson, A., and Wood, P.: Interdisciplinary perspectives on processes in the hyporheic zone, Ecohydrology, 4, 481-499, 2011a.

Krause, S., Hannah, D. M., and Blume, T.: Interstitial pore-water temperature dynamics across a pool-riffle-pool sequence, Ecohydrology, 4, 549-563, $2011 \mathrm{~b}$.

Krause, S., Munz, M., Tecklenburg, C., and Binley, A.: The effect of groundwater forcing on hyporheic exchange: Reply to comment on 'Munz M, Krause S, Tecklenburg C, Binley A. Reducing monitoring gaps at the aquifer-river interface by modelling groundwater surfacewater exchange flow patterns, Hydrological Processes, Hydrological Processes, 26, 15891592, 2012.

Krause, S., Tecklenburg, C., Munz, M., and Naden, E.: Streambed nitrogen cycling beyond the hyporheic zone: Flow controls on horizontal patterns and depth distribution of nitrate and dissolved oxygen in the upwelling groundwater of a lowland river, Journal of Geophysical Research: Biogeosciences, 118, 54-67, 2013.

Kumar, S., Merwade, V., Kam, J., \& Thurner, K.: Streamflow trends in Indiana: Effects of long term persistence, precipitation and subsurface drains, Journal of Hydrology,374(1), 171-183, 2009.

Kutija, V., \& Thi Minh Hong, H.: A numerical model for assessing the additional resistance to flow introduced by flexible vegetation, Journal of Hydraulic Research, 34(1), 99-114, 1996.

Laenen, A. and Bencala, K. E.: Transient storage assessments of dye-tracer injections in rivers of the willamette basin, oregon, JAWRA Journal of the American Water Resources Association, 37, 367-377, 2001.

Larkin, R. G. and Sharp, J. M.: On the relationship between river-basin geomorphology, aquifer hydraulics, and groundwater flow direction in alluvial aquifers, Geological Society of America Bulletin, 104, 1608-1620, 1992. 
Hydrol. Earth Syst. Sci. Discuss., doi:10.5194/hess-2016-683, 2017

Manuscript under review for journal Hydrol. Earth Syst. Sci.

Published: 9 January 2017

(c) Author(s) 2017. CC-BY 3.0 License.

Latterell, J., J. Bechtold, T. O'Keefe, R. Van Pelt, and R. Naiman: Dynamic patch mosaics and channel movement in an unconfined river valley of the Olympic Mountains, Freshwater Biol., 51, 523-544, 2006.

Lautz, L. K., Siegel, D. I., and Bauer, R. L.: Impact of debris dams on hyporheic interaction along a semi-arid stream, Hydrological Processes, 20, 183-196, 2006.

Lautz, L. K., Siegel, D. I., and Bauer, R. L.: Dye tracing through Sinks Canyon: incorporating advanced hydrogeology into the University of Missouri's geology field camp, Journal of Geoscience Education, 55, 197-201, 2007.

Lautz, L. K., \& Fanelli, R. M. :Seasonal biogeochemical hotspots in the streambed around restoration structures, Biogeochemistry,91(1), 85-104, 2008.

Lautz, L. K., Kranes, N. T., and Siegel, D. I.: Heat tracing of heterogeneous hyporheic exchange adjacent to in-stream geomorphic features,Hydrological processes, 24, 3074-3086, 2010.

Laudon, H., Sjöblom, V., Buffam, I., Seibert, J., and Mörth, M.: The role of catchment scale and landscape characteristics for runoff generation of boreal streams, Journal of Hydrology, 344, 198-209, 2007.

Lee, Joong Gwang, and James P. Heaney: Estimation of urban imperviousness and its impacts on storm water systems. Journal of Water Resources Planning and Management,129,5,419-426, 2003.

Li, S., Lobb, D.A., Tiessen, K.H.D.: Modeling tillage-induced morphological features in cultivated landscapes. Soil Tillage Res. 103, 33-45, 2009.

Loheide, S. P., and J. D. Lundquist: Snowmelt-induced diel fluxes through the hyporheic zone, Water Resour. Res., 45, W07404, doi:10.1029/2008WR007329, 2009.

Lowrance, R., et al.: Water quality functions of riparian forest buffers in Chesapeake Bay watersheds, Environ. Manage. N. Y., 21, 687-712, doi:10.1007/s002679900060, 1997.

Lowrance R.: Riparian forest ecosystems as filters for non-point source pollution. In: Success, Limitations, and Frontiers in Ecosystem Science (Eds M.L. Pace \& P.M. Groffman,), pp. 113-141. Springer-Verlag, New York,1998.

Maalim, F. K., Melesse, A. M., Belmont, P., \& Gran, K. B.: Modeling the impact of land use changes on runoff and sediment yield in the Le Sueur watershed, Minnesota using GeoWEPP, Catena, 107, 35-45, 2013.

Malard, F., Tockner, K., DOLE-OLIVIER, M.-J., and Ward, J.: A landscape perspective of surface-subsurface hydrological exchanges in river corridors, Freshwater Biology, 47, 621-640, 2002.

Malcolm, I., Soulsby, C., Youngson, A., Hannah, D., McLaren, I., and Thorne, A.: Hydrological influences on hyporheic water quality:implications for salmon egg survival, Hydrological Processes, 18, 1543-1560, 2004.

Malcolm I, Soulsby, C., Youngson, F., and Hannah, D. M.: Catchment-scale controls on groundwater-surface water interactions in the hyporheic zone: Implications for salmon embryo survival, River Research and Applications, 21, 977-989, 2005.

Malcolm, I. a., Middlemas, C. a., Soulsby, C., Middlemas, S. J., and Youngson, a. F.: Hyporheic zone processes in a canalised agricultural stream: implications for salmonid embryo survival, Fundamental and Applied Limnology / Archiv für Hydrobiologie, 176, 319-336, 10 doi:10.1127/1863-9135/2010/0176-0319, 2010.

35 Malzone, J. M., Anseeuw, S. K., Lowry, C. S., and Allen-King, R.: Temporal Hyporheic Zone Response to Water Table Fluctuations, Groundwater, 2015.

Malzone, J. M., Lowry, C. S., andWard, A. S.: Response of the hyporheic zone to transient groundwater fluctuations on the annual and storm event time scales, Water Resources Research, 2016.

Marion, A., Bellinello, M., Guymer, I., and Packman, A.: Effect of bed form geometry on the penetration of nonreactive solutes into a streambed, Water Resources Research, 38, 27-1, 2002.

Martinet, M. C., Vivoni, E. R., Cleverly, J. R., Thibault, J. R., Schuetz, J. F., and Dahm, C. N.: On groundwater fluctuations, evapotranspiration, and understory removal in riparian corridors, Water Resources Research, 45, 2009.

Marzadri, A., Tonina, D., Bellin, A., Vignoli, G., and Tubino, M.: Semianalytical analysis of hyporheic flow induced by alternate bars, Water Resources Research, 46, 2010.

45 Marzadri, A., Tonina, D., McKean, J. A., Tiedemann, M. G., and Benjankar, R. M.: Multi-scale streambed topographic and discharge effects on hyporheic exchange at the stream network scale in confined streams, Journal of Hydrology, 519, 19972011, 2014.

Mason, S. J., McGlynn, B. L., and Poole, G. C.: Hydrologic response to channel reconfiguration on Silver Bow Creek, Montana, Journal of Hydrology, 438, 125-136, 2012. 
Hydrol. Earth Syst. Sci. Discuss., doi:10.5194/hess-2016-683, 2017

Manuscript under review for journal Hydrol. Earth Syst. Sci.

Published: 9 January 2017

(c) Author(s) 2017. CC-BY 3.0 License.

McGlynn, B. L., \& Seibert, J.: Distributed assessment of contributing area and riparian buffering along stream networks, Water resources research, 39(4), 2003.

McGonigle, D., Burke, S., Collins, A., Gartner, R., Haft, M., Harris, R., Haygarth, P., Hedges, M., Hiscock, K., and Lovett, A.: Developing Demonstration Test Catchments as a platform for transdisciplinary land management research in England and Wales, Environmental Science: Processes \& Impacts, 16, 1618-1628, 2014.

McGuire, K. J. and McDonnell, J. J.: Hydrological connectivity of hillslopes and streams: Characteristic time scales and nonlinearities, Water Resources Research, 46, 2010.

McGuire, K. J., et al. The role of topography on catchment scale water residence time. Water Resources Research, 41, 5, 2005.

10 McHenry, M. L., Shott, E., Conrad, R. H., \& Grette, G. B.: Changes in the quantity and characteristics of large woody debris in streams of the Olympic Peninsula, Washington, USA (1982-1993), Canadian Journal of Fisheries and Aquatic Sciences, 55(6), 1395-1407, 1998.

McMillan, S. K., Tuttle, A. K., Jennings, G. D., \& Gardner, A.: Influence of Restoration Age and Riparian Vegetation on Reach Scale Nutrient Retention in Restored Urban Streams, JAWRA Journal of the American Water Resources Association, 50(3), 626-638, 2014.

Merill, L. and Tonjes, D. J.: A Review of the Hyporheic Zone, Stream Restoration, and Means to Enhance Denitrification, Critical Reviews in Environmental Science and Technology, 44, 2337-2379, 2014.

Millington, C. E., \& Sear, D. A.: Impacts of river restoration on small-wood dynamics in a low-gradient headwater stream, Earth Surface Processes and Landforms,32(8), 1204-1218, 2007.

20 Minshall, G. W., Cummins, K. W., Petersen, R. C., Cushing, C. E., Bruns, D. A., Sedell, J. R., and Vannote, R. L.: Developments in stream ecosystem theory, Canadian Journal of Fisheries and Aquatic Sciences, 42, 1045-1055, 1985.

Mishra, N., Khare, D., Gupta, K. K., \& Shukla, R.: Impact of Land Use Change on Groundwater-A Review,Advances in Water Resource and Protection, 2(28), 28-41, 2014.

Mitchell-Bruker, S. and Haitjema, H. M.: Are Water Tables a Subdued Replica of the Topography?, Ground water, pp. 781-

786, 2005.

Mizuba, M.M., Hammel, J.E.: Infiltration rates in fall-seeded winter wheat fields following preplant subsoil tillage, J. Soil Water Conserv, 56, 133-137, 2001.

Montgomery, D. R., \& Piégay, H.: Wood in rivers: interactions with channel morphology and processes, Geomorphology,51(1-3), 1-5, 2003.

30 Morrice, J. a., Valett, H. M., Dahm, C. N., and Campana, M. E.: Alluvial Characteristics, Groundwater-SurfaceWater Exchange and Hydrological Retention in Headwater Streams, Hydrological Processes, 11, 253-267, 1997.

Munz, M., Krause, S., Tecklenburg, C., and Binley, A.: Reducing monitoring gaps at the aquifer-river interface by modelling groundwater surface water exchange flow patterns, Hydrological Processes, 25, 3547-3562, 2011.

Mutz, M.: Influences of woody debris on 5 flow patterns and channel morphology in a low energy, sand-bed stream reach,

International Review of Hydrobiology, 85, 107-121, doi:10.1002/(SICI)1522-2632(200003)85:1<107::AIDIROH107>3.0.CO;2-L, 2000.

Mutz, M. and Rohde, A.: Processes of Surface-Subsurface Water Exchange in a Low Energy Sand-Bed Stream, International Review of Hydrobiology, 88, 290-303, doi:10.1002/iroh.200390026, http://dx.doi.org/10.1002/iroh.200390026, 2003.

Naiman, R. J., \& Latterell, J. J.: Principles for linking fish habitat to fisheries management and conservation, Journal of Fish Biology, 67(sB), 166-185, 2005.

Nanson, G. and Croke, J.: A genetic classification of floodplains, Geomorphology, 4, 459-486, 1992.

Newbold, J., O'neill, R., Elwood, J., and Van Winkle, W.: Nutrient spiralling in streams: implications for nutrient limitation and invertebrate activity, American Naturalist, pp. 628-652, 1982.

Newbold, J. D., Elwood, J. W., O’Neill, R. V., and Winkle, W. V.: Measuring nutrient spiralling in streams, Canadian Journal of Fisheries and Aquatic Sciences, 38, 860-863, 1981.

O' Connor, Ben L., and Judson W. Harvey. Scaling hyporheic exchange and its influence on biogeochemical reactions in aquatic ecosystems, Water Resources Research, 44.12, 2008.

Orghidan, T.: Ein neuer Lebensraum des unterirdischen Wassers: der hyporheische Biotop, Arch. Hydrobiol, 55, 392-414, 1959. 
Hydrol. Earth Syst. Sci. Discuss., doi:10.5194/hess-2016-683, 2017

Manuscript under review for journal Hydrol. Earth Syst. Sci.

Published: 9 January 2017

(c) Author(s) 2017. CC-BY 3.0 License.

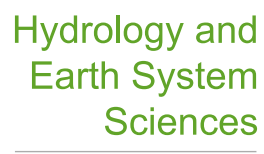

Discussions

(c) $\underset{\mathrm{Br}}{\text { (i) }}$

Osei, N. A., Harvey, G. L., \& Gurnell, A. M. :The early impact of large wood introduction on the morphology and sediment characteristics of a lowland river, Limnologica-Ecology and Management of Inland Waters,54, 33-43, 2015.

Owuor, S. O., Butterbach-Bahl, K., Guzha, A. C., Rufino, M. C., Pelster, D. E., Díaz-Pinés, E., \& Breuer, L.: Groundwater recharge rates and surface runoff response to land use and land cover changes in semi-arid environments, Ecological Processes,5(1), 16, 2016.

Packman, A.I., Bencala. K.E.: Modeling surface-subsurface hydrological interactions. In: Jones JB, Mulholland PJ, editors. Streams and Groundwaters. San Diego: Academic Press; 2000.

Packman, A. I. and Brooks, N. H.: Hyporheic exchange of solutes and colloids with moving bed forms, Water Resources Research, 37, 2591-2605, 2001.

Packman, A. I. and MacKay, J. S.: Interplay of stream-subsurface exchange, clay particle deposition, and streambed evolution, Water Resources Research, 39,20 1-10, 2003.

Packman AI, Salehin M. Relative roles of stream flow and sedimentary conditions in controlling hyporheic exchange, Hydrobiologia, 494:291-7, 2003.

Packman, A. I., Salehin, M., and Zaramella, M.: Hyporheic exchange with gravel beds: basic hydrodynamic interactions and bedform-induced advective flows, Journal of Hydraulic Engineering, 130, 647-656, 2004.

Pásztor, L., Pálfai, I., Bozán, Cs., KÅrösparti, J., Szabó, J., Bakacsi Zs, Kuti, L.:. Spatial stochastic modelling of inland inundation hazard. 9th AGILE Conference on GIS, Visegrád, pp. 139-143, 2006.

Paul, M. J. and Meyer, J. L.: Streams in the urban landscape, Annual Review of Ecology and Systematics, pp. 333-365, 2001.

20 Payn, R., Gooseff, M., McGlynn, B., Bencala, K., and Wondzell, S.: Channel water balance and exchange with subsurface flow along a mountain headwater stream in Montana, United States, Water Resources Research, 45, 2009.

Peterjohn, W.T., Correll, D.L. : Nutrient dynamics in an agricultural watershed. Ecology 65: 1466-75, 1984.

Peterson, E. W. and Benning, C.: Factors influencing nitrate within a low-gradient agricultural stream, Environmental earth sciences, 68, 1233-1245, 2013.

25 Phillips, J. D.:Log-jams and avulsions in the San Antonio River Delta, Texas, Earth Surface Processes and Landforms,37(9), 936-950, 2012.

Piégay, H., \& Gurnell, A. M.: Large woody debris and river geomorphological pattern: examples from SE France and S. England, Geomorphology, 19(1), 99-116, 1997.

Piégay, H., \& Marston, R. A. Distribution of large woody debris along the outer bend of meanders in the Ain River, France, 30 Physical Geography, 19(4), 318-340, 1998.

Pinay, G., Gumiero, B., Tabacchi, E., Gimenez, O., TABACCHI-PLANTY, A. M., Hefting, M. M., Burt, T. P., Black, V. A., Nilsson, C.,Iordache, V., et al.: Patterns of denitrification rates in European alluvial soils under various hydrological regimes, Freshwater Biology, 52,252-266, 2007.

Pinay, G., O'Keefe, T. C., Edwards, R. T., and Naiman, R. J.: Nitrate removal in the hyporheic zone of a salmon river in

Alaska, River Research and Applications, 25, 367-375, 2009.

Pinder, G. F. and Sauer, S. P.: Numerical simulation of flood wave modification due to bank storage effects, Water Resources Research, 7, 63-70, 1971.

Poole, G. C., \& Berman, C. H: An ecological perspective on in-stream temperature: natural heat dynamics and mechanisms of human-caused thermal degradation, Environmental management, 27(6), 787-802, 2001.

40 Poole, G. C., Stanford, J. A., Running, S. W., and Frissell, C. A.: Multiscale geomorphic drivers of groundwater flow paths: subsurface hydrologic dynamics and hyporheic habitat diversity, Journal of the North American Benthological Society, 25, 288-303, 2006.

Pretty, J., Hildrew, A., and Trimmer, M.: Nutrient dynamics in relation to surface-subsurface hydrological exchange in a groundwater fed chalk stream, Journal of Hydrology, 330, 84-100, 2006.

45 Pryshlak, T.T.: Multiscale Hyporheic Exchange Through Strongly Heterogeneous Sediments, Ph.D. thesis, The Ohio State University, 2015.

Revelli, R., Boano, F., Camporeale, C., and Ridolfi, L.: Intra-meander hyporheic flow in alluvial rivers, Water Resources Research, 44, 1-10,2008.

Rodriguez-Iturbe, Ignacio: Ecohydrology: A hydrologic perspective of climate-soil-vegetation dynamies. Water Resources

Research, 36, 1, 3-9, 2000. 
Hydrol. Earth Syst. Sci. Discuss., doi:10.5194/hess-2016-683, 2017

Manuscript under review for journal Hydrol. Earth Syst. Sci.

Published: 9 January 2017

(c) Author(s) 2017. CC-BY 3.0 License.

Ryan, R. J., Welty, C., and Larson, P. C.: Variation in surface water-groundwater exchange with land use in an urban stream, Journal of hydrology, 392, 1-11, 2010.

Szabó, J.,: Anthropogenic geomorphology: subject and system. In: Szabó, J., Dávid, L., Lóczy, D. (Eds.), Anthropogenic Geomorphology, Springer, New York, pp. 3-12, 2006.

Salehin, M., Packman, A. I., and Wörman, A.: Comparison of transient storage in vegetated and unvegetated reaches of a small agricultural stream in Sweden: seasonal variation and anthropogenic manipulation, Advances in Water Resources, 26, 951-964, 2003.

Salehin, M., Packman, A. I., and Paradis, M.: Hyporheic exchange with heterogeneous streambeds: Laboratory experiments and modeling,Water Resources Research, 40, 2004.

10 Santos, R. G., Sturaro, J. R., Marques, M. L., \& de Faria, T. T:. GIS Applied to the Mapping of Land Use, Land Cover and Vulnerability in the Outcrop Zone of the Guarani Aquifer System. Procedia Earth and Planetary Science, 15, 553-559, 2005.

Savant, S. A., Reible, D. D., and Thibodeaux, L. J.: Convective transport within stable river sediments, Water Resources Research, 23,1763-1768, 1987.

Sawyer, A., Kaplan, L., Lazareva, O., and Michael, H.: Hydrologic dynamics and geochemical responses within a floodplain aquifer and hyporheic zone during Hurricane Sandy, Water Resources Research, 50, 4877-4892, 2014.

Sawyer, A. H. and Cardenas, M. B.: Hyporheic flow and residence time distributions in heterogeneous cross-bedded sediment, Water resources research, 45, 2009.

Sawyer, A. H. and Cardenas, M. B.: Effect of experimental wood addition on hyporheic exchange and thermal dynamics in a losing meadow stream, Water Resources Research, 48, 2012.

20 Sear, D., Armitage, P., and Dawson, F.: Groundwater dominated rivers, Hydrological Processes, 13, 255-276, 1999.

Sear, D. A., Millington, C. E., Kitts, D. R., \& Jeffries, R. : Logjam controls on channel: floodplain interactions in wooded catchments and their role in the formation of multi-channel patterns, Geomorphology,116(3), 305-319, 2010.

Schade, J.D., Marti, E., Welter, J.R., Fisher, S.G., and Grimm, N.B.: Sources of nitrogen to the riparian zone of a desert stream: implications for riparian vegetation and nitrogen retention, Ecosystems (N.Y. Print), 5: 68-79. doi:10.1007/s10021-

\section{001-0056-6, 2002.}

Schade, J. D., Welter, J. R., Martí, E., \& Grimm, N. B. : Hydrologic exchange and N uptake by riparian vegetation in an arid-land stream, Journal of the North American Benthological Society, 24(1), 19-28, 2005.

Schmadel, N. M., Ward, A. S., Lowry, C. S., \& Malzone, J. M.: Hyporheic exchange controlled by dynamic hydrologic boundary conditions, Geophysical Research Letters,43(9), 4408-4417, 2016.

30 Schottler, S. P., Ulrich, J., Belmont, P., Moore, R., Lauer, J., Engstrom, D. R., \& Almendinger, J. E.: Twentieth century agricultural drainage creates more erosive rivers, Hydrological processes, 28(4), 1951-1961, 2014.

Simon, A., Rinaldi, M.: Disturbance, stream incision and channel evolution: the roles of excess transport capacity and boundarymaterials in controlling channel response, Geomorphology, 79:361-383, 2006.

Singh, P., Wu, J. Q., McCool, D. K., Dun, S., Lin, C. H., \& Morse, J. R.:Winter hydrologic and erosion processes in the US

Palouse region: Field experimentation and WEPP simulation, Vadose Zone Journal, 8(2), 426-436.

Soulsby, C., Malcolm, I., and Youngson, A.: Hydrochemistry of the hyporheic zone in salmon spawning gravels: a preliminary assessment in a degraded agricultural stream, Regulated Rivers: Research \& Management, 17, 651-665, 2001.

Stanford, J. A. and Ward, J.: An ecosystem perspective of alluvial rivers: connectivity and the hyporheic corridor, Journal of the North American Benthological Society, pp. 48-60, 1993.

40 Stofleth, J. M., Shields, F. D., and Fox, G. a.: Hyporheic and total transient storage in small, sand-bed streams, Hydrological Processes, 22, 1885-1894, 2008.

Stonedahl, S. H., Harvey, J. W., Detty, J., Aubeneau, A., and Packman, A. I.: Physical controls and predictability of stream hyporheic flow evaluated with a multiscale model, Water Resources Research, 48, 1-15, 2012.

Stonedahl, S. H., Harvey, J. W., and Packman, A. I.: Interactions between hyporheic flow produced by stream meanders, bars, and dunes, Water Resources Research, 49, 5450-5461, 2013.

Storey, R. G., Howard, K. W., and Williams, D. D.: Factors controlling riffle-scale hyporheic exchange flows and their seasonal changes in a gaining stream: A three-dimensional groundwater flow model, Water Resources Research, 39, 2003.

Strauch, M., Lima, J. E., Volk, M., Lorz, C., and Makeschin, F.: The impact of Best Management Practices on simulated streamflow and sediment load in a Central Brazilian catchment, Journal of environmental management, 127, S24-S36, 2013. 
Hydrol. Earth Syst. Sci. Discuss., doi:10.5194/hess-2016-683, 2017

Manuscript under review for journal Hydrol. Earth Syst. Sci.

Published: 9 January 2017

(c) Author(s) 2017. CC-BY 3.0 License.
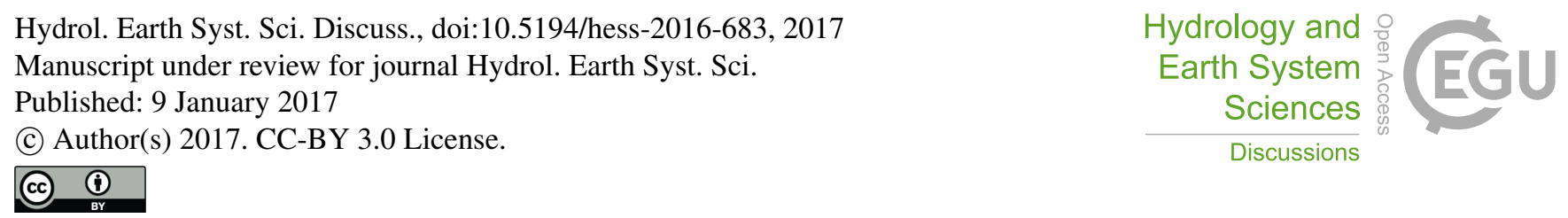

Streetly, M. and Shepley, M.: Final Report, East Shropshire Permo-Triassic Sandstone Groundwater Modelling Project-Task 8, Report of the Environment Agency of England and Wales, UK, 2005.

Stromberg, J.C., Patten, D.T.: Instream flow requirements for cottonwoods at Bishop Creek, Inyo County, California. Rivers 2, 1e11, 1991.

5 Stromberg JC, Tiller R, Richter B.: Effects of groundwater on riparian vegetation of semiarid regions: San Pedro, Arizona: Ecological Applications 6: 113-131, 1996.

Tanakamaru, H. and Kadoya, M.: Effects of climate change on the regional hydrological cycle in Japan, IAHS PUBLICATION, pp. 535-535,1993.

Tetzlaff, D., Soulsby, C., Hrachowitz, M., and Speed, M.: Relative influence of upland and lowland headwaters on the isotope hydrology and transit times of larger catchments, Journal of Hydrology, 400, 438-447, 2011.

Tonina, D.: Interaction between river morphology and intra-gravel flow paths within the hyporheic zone, Ph.D. thesis, University of Idaho, 152005.

Tonina, D. and Buffington, J. M.: Hyporheic exchange in gravel bed rivers with pool-riffle morphology: Laboratory experiments and three dimensional modeling, Water Resources Research, 43, 1-16, doi:10.1029/2005WR004328, 2007.

15 Tonina, D. and Buffington, J. M.: Hyporheic exchange in mountain rivers I: Mechanics and environmental effects, Geography Compass, 3,1063-1086, doi:10.1111/j.1749-8198.2009.00226.x, 2009.

Tonina, D. and Buffington, J. M.: Effects of stream discharge, alluvial depth and bar amplitude on hyporheic flow in poolriffle channels, Water Resources Research, 47, 2011.

Tooth, S. and Nanson, G. C.: The role of vegetation in the formation of anabranching channels in an ephemeral river,

Northern plains, arid central Australia, Hydrological processes, 14, 3099-3117, 2000.

Toth, J.: A theoretical analysis of groundwater flow in small drainage basins, Journal of geophysical research, 68, 47954812, 1963.

Trauth, N., Schmidt, C., Vieweg, M., Oswald, S. E., \& Fleckenstein, J. H.: Hydraulic controls of in stream gravel bar hyporheic exchange and reactions, Water Resources Research,51(4), 2243-2263, 2015.

25 Triska, F. J., Duff, J. H., and Avanzino, R. J.: Patterns of hydrological exchange and nutrient transformation in the hyporheic zone of a gravel-bottom stream: examining terrestrial-aquatic linkages, Freshwater Biology, 29, 259-274, 1993.

Vannote, R. L., Minshall, G. W., Cummins, K. W., Sedell, J. R., and Cushing, C. E.: The river continuum concept, Canadian journal of fisheries and aquatic sciences, 37, 130-137, 1980.

$30 \quad$ Bulletin, 66, 479, 1968.

Vervier, P., Gibert, J., Marmonier, P., and Dole-Olivier, M.-J.: A perspective on the permeability of the surface freshwatergroundwater ecotone, Journal of the North American Benthological Society, pp. 93-102, 1992.

Vieira, D.A., Dabney, S.M., : Modeling edge effects of tillage erosion. Soil Tillage Res. 111, 197-207, 2011.

Voltz, T., Gooseff, M., Ward, A. S., Singha, K., Fitzgerald, M., and Wagener, T.: Riparian hydraulic gradient and stream-

groundwater exchange dynamics in steep headwater valleys, Journal of Geophysical Research: Earth Surface, 118, 953-969,

2013.

Wagenhoff, a. and Olsen, D.: Does large woody debris affect the hyporheic ecology of a small New Zealand pasture stream?, New Zealand Journal of Marine and Freshwater Research, 48, 547-559, doi:10.1080/00288330.2014.924539, http://www.tandfonline.com/doi/abs/10.1080/00288330.2014.924539, 2014.

40 Wagner, F. H. and Bretschko, G.: Riparian trees and flow paths between the hyporheic zone and groundwater in the Oberer Seebach, Austria,International Review of Hydrobiology, 88, 129-138, doi:10.1002/iroh.200390009, 2003.

Walsh, C. J., T. D. Fletcher, and A. R. Ladson: Stream restoration in urban catchments through redesigning stormwater systems: looking to the catchment to save the stream, Journal of theNorth American Benthological Society, 24:690-705, 2005.

45 Wang, D., \& Hejazi, M.: Quantifying the relative contribution of the climate and direct human impacts on mean annual streamflow in the contiguous United States, Water Resources Research,47(10), 2011.

Ward, A. S.: The evolution and state of interdisciplinary hyporheic research, Wiley Interdisciplinary Reviews: Water, 3, 83$103,2016$. 
Hydrol. Earth Syst. Sci. Discuss., doi:10.5194/hess-2016-683, 2017

Manuscript under review for journal Hydrol. Earth Syst. Sci.

Published: 9 January 2017

(c) Author(s) 2017. CC-BY 3.0 License.

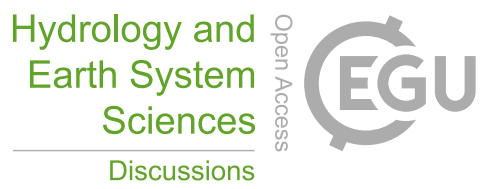

(c) (i)

Ward, A. S., Fitzgerald, M., Gooseff, M. N., Voltz, T. J., Binley, A. M., and Singha, K.: Hydrologic and geomorphic controls on hyporheic exchange during base flow recession in a headwater mountain stream, Water Resources Research, 48, $1-20,2012$.

Ward, J. and Stanford, J.: The serial discontinuity concept: extending the model to floodplain rivers, Regulated Rivers:

Research \& Management, 10, 159-168, 1995.

White, D. S.: Perspectives on defining and delineating hyporheic zones, Journal of the North American Benthological Society, pp. 61-69,1993.

Winter, T. C.: Ground water and surface water: a single resource, DIANE Publishing Inc., 1998.

Woessner, W. W.: Stream and fluvial plain ground water interactions: rescaling hydrogeologic thought, Groundwater, 38, 423-429, 2000.

Wolock, D. M., Winter, T. C., and McMahon, G.: Delineation and evaluation of hydrologic-landscape regions in the United States using geographic information system tools and multivariate statistical analyses, Environmental Management, 34, S71S88, 2004.

Wohl, E. : Floodplains and wood, Earth-Science Reviews, 123, 194-212, 2013.

15 Wondzell, S. and Gooseff, M.: Geomorphic controls on hyporheic exchange across scales: watersheds to particles, Treatise on Geomorphology,9, 203-218, 2013.

Wondzell, S. M.: Effect of morphology and discharge on hyporheic exchange flows in two small streams in the Cascade Mountains of Oregon, USA, Hydrological Processes, 20, 267-287, 2006.

Wondzell, S. M.: The role of the hyporheic zone across stream networks, Hydrological Processes, 25, 3525-3532, 2011.

20 Wondzell, S. M. and Swanson, F. J.: Seasonal and storm dynamics of the hyporheic zone of a 4th-order mountain stream I:Hydrologic processes, Journal of the North American Benthological Society, pp. 3-19, 1996.

Wondzell, S. M. and Swanson, F. J.: Floods, channel storage and the hyporheic zone, Water Resources Research, 35, 555$567,1999$.

Wondzell, S. M., LaNier, J., Haggerty, R., Woodsmith, R. D., and Edwards, R. T.: Changes in hyporheic exchange flow following experimental wood removal in a small, low-gradient stream, Water Resources Research, 45, 1-13, doi:10.1029/2008WR007214, 2009.

Wondzell, S. M., Gooseff, M. N., and McGlynn, B. L.: An analysis of alternative conceptual models relating hyporheic exchange flow to diel fluctuations in discharge during baseflow recession, Hydrological processes, 24, 686-694, 2010.

Woods, R., Sivapalan, M., and Duncan, M.: Investigating the representative elementary area concept: An approach based on 30 field data,Hydrological Processes, 9, 291-312, 1995.

Wörman, A., Packman, A. I., Marklund, L., Harvey, J.W., and Stone, S. H.: Exact three-dimensional spectral solution to surface-groundwater interactions with arbitrary surface topography, Geophysical research letters, $33,2006$.

Wörman, A., Packman, A. I., Marklund, L., Harvey, J. W., and Stone, S. H.: Fractal topography and subsurface water flows from fluvial bedforms to the continental shield, Geophysical Research Letters, 34, 2007.

35 Wright, K. K., Baxter, C. V., and Li, J. L.: Restricted hyporheic exchange in an alluvial river system: implications for theory and management,Journal of the North American Benthological Society, 24, 447-460, 2005.

Wroblicky, G. J., Campana, M. E., Valett, H. M., and Dahm, C. N.: Seasonal variation in surface-subsurface water exchange and lateral hyporheic area of two stream-aquifer systems, Water Resources Research, 34, 317, 1998.

Zaletaev, V.: Ecotones and problems of their management in irrigation regions, Tech. rep., Cambridge University Press, 1997. 